\title{
AVALIAÇÃO DA FERTILIDADE DO SOLO E DO ESTADO NUTRICIONAL DE POMARES DE LARANJEIRA 'VALÊNCIA' E SUAS RELAÇÕES COM A PRODU்TIVIDADE E A QUALIDADE DOS FRUTOS
}

\author{
ALBERTO CARLOS DE CAMPOS BERNARDI \\ Engenheiro Agrônomo
}

Orientador: Prof. Dr. QUIRINO AUGUSTO DE CAMARGO CARMELLO

\begin{abstract}
Dissertação apresentada à Escola Superior de Agricultura "Luiz de Queiroz", da Universidade de São Paulo, para a obtenção do título de Mestre em Agronomia, Área de Concentração: Solos e Nutrição de Plantas.
\end{abstract}

\section{PIRACICABA}

Estado de São Paulo - Brasil

Novembro - 1995 
Dados Internaciona is de Catalogação na Publicação (CIP)

DIVISÃo DE BIBLIOTECA E DOCUMENTAÇĀO - Campus "Luiz de Que iroz"/USP

Bernardi, Alberto Carlos de Campos

Aval iação da fertil idade do solo e do estado nutricional de poma res de laranjeira "valência" e suas relaçōes com a produtividade e a qual idade dos frutos. Piracicaba, 1995.

98p.

Diss. (Mestre) - ESALQ

Bibl iografia.

1. Laranaja valência - Produtividade 2. Nutriente em Laranja valência - Aval iação 3. Solo - Fertilidade - Análise I. Escola Supe rior de Agricultura Luiz de Queiroz, Piracicaba

CDD 634.31

631.42 


\section{AVALIAÇÃO DA FERTILIDADE DO SOLO E DO ESTADO NUTRICIONAL DE POMARES LARANJEIRAVALÊNCIA E SUAS RELAÇŌES COM A PRODUTIVIDADE E A QUALIDADE DOS FRUTOS}

ALBERTO CARLOS DE CAMPOS BERNARDI

Aprovada em : 12.02.1996

Comissão julgadora:

Prof. Dr. Quirino Augusto de Camargo Carmello ESALQ/USP

Prof. Dr. Antônio Roque Dechen ESALQ/USP

Prof. Dr. Francisco de Assis Alves Mourão Filho ESALQ/USP

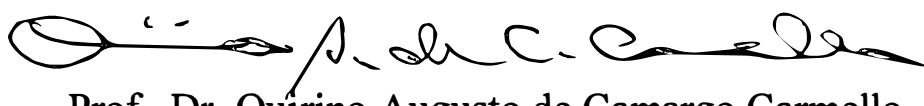

Prof. Dr. Quirino Augusto de Camargo Carmello

Orientador 
Ao Criador por mais essa oportunidade, Agradeço.

Aos meus pais, Alberto e Hadiê e aos irmãos, Maria Paula e Fernando pelo apoio, confiança e incentivo, Ofereço.

Para Marta, que sempre soube compartilhar todos os momentos, Dedico. 


\section{AGRADECIMENTOS}

Ao Dr. Quirino Augusto de Camargo Carmello pela orientação e apoio que muito contribuíram para a realização desse trabalho;

Ao Setor de Nutrição Mineral de Plantas do Departamento de Química da Escola Superior de Agricultura "Luiz de Queiroz", pela infra-estrutura e apoio durante a realização desse trabalho;

Ao Eng. Agr. Fernando Tannuri, da Coordenadoria de Assistência Técnica Integral - CATI de Araraquara, pelo auxílio na escolha das áreas e condução do trabalho no campo;

Ao Dr. Frederico Pimentel Gomes, pelos ensinamentos nas análises estatísticas;

Aos funcionários do Setor de Nutrição de Plantas da ESALQ, Edinéia Cristina S. Mondoni, Lourdes A. Dário de González, Lúcia Helena S. Pavan Forti, Nivanda Maria de Moura, pelo auxílio na condução das análises de folhas; Mirtes Ventura Sesso e Sueli Maria Amaral Campos Bovi que, mesmo indiretamente, sempre auxiliaram, e Fernando Éder Ré pela realização das análises de solo;

Ao Eng. Agr. Edson Roberto Teramoto, pelo auxílio na classificação dos solos;

Ao Dr. Francisco de Assis Alves Mourão Filho, pelo auxílio na redação do Summary;

À Bibliotecária Kátia Maria de Andrade Ferraz, pelo auxílio e organização das referências bibliográficas;

Aos funcionários da Biblioteca Central da ESALQ, Álvaro Sobreiro Filho, Airton Luís Barbosa, Luzia Fátima S. Possato, Marilene Monteiro Frasson; Paulo Veríssimo Júnior; Ronaldo A. Caprecci, Roseli Terezinha de Barros; Silvana Cristina Nascimento de Oliveira e Sílvio Douglas Dias Bacheta;

Ao Conselho Nacional de Desenvolvimento Tecnológico - $\mathrm{CNPq}$, pelo apoio financeiro durante o curso, através da concessão da Bolsa de Pesquisa. 
Página

RESUMO.

vii

SUMMARY

ix

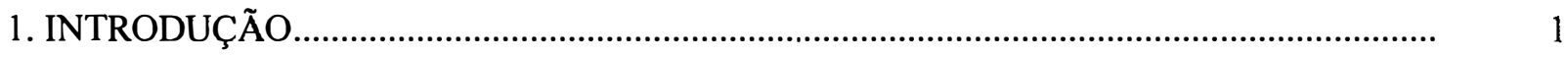

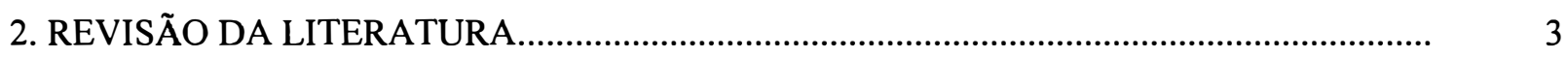

2.1. Avaliação da fertilidade do solo e do estado nutricional e na cultura dos citros.

2.1.1. Calibração da análise de solo...

2.1.2. Recomendação de adubação de citros no Brasil

2.2. Levantamento do estado nutricional.

2.3. Propriedades do solo.

2.4. Nutrição mineral dos citros.

2.5. Níveis críticos e faixas adequadas.

2.6. Nutrição e qualidade dos frutos cítricos.

2.7. Produção Relativa (PR\%).

2.8. Regressão linear múltipla.

3. MATERIAL E MÉTODOS.

3.1. Clima.

3.2. Material de origem e solos.

3.3. Variedades Copa e Porta-enxerto.

3.4. Histórico e agrupamento dos pomares.

3.5. Amostragem de solo, folhas e frutos.

3.6. Análises químicas do solo.

3.7. Análises granulométricas do solo

3.8. Análises químicas das folhas.

3.9. Análises tecnológicas dos frutos.

3.10. Produção Relativa (\%). 


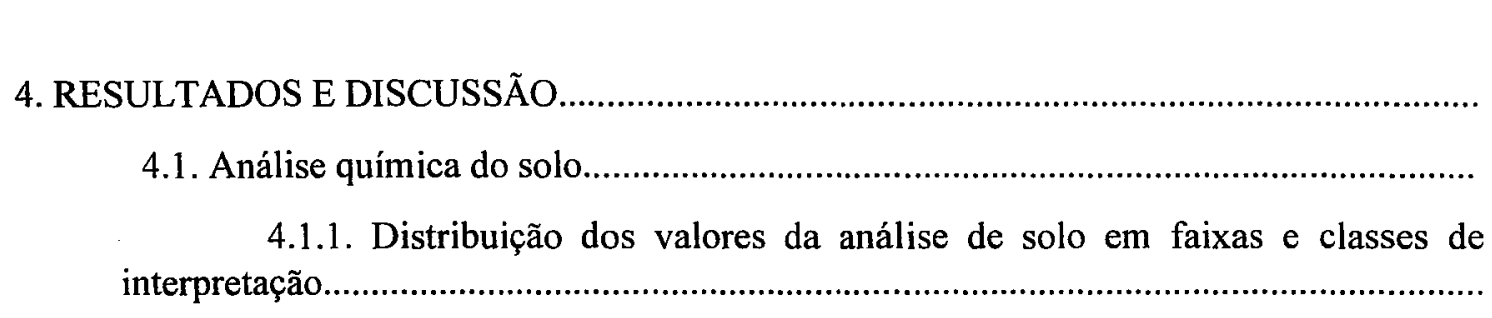

4.1.2. Análise granulométrica e classificação dos solos..................................... 46

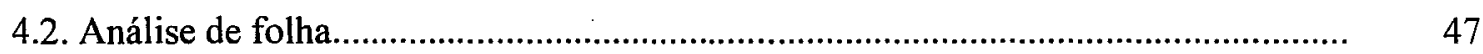

4.2.1. Distribuição dos valores da análise foliar em faixas e classes de interpretação.

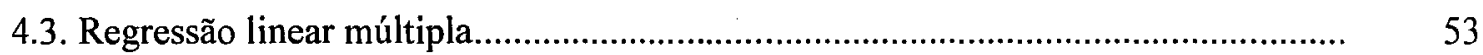

4.3.1. Parâmetros do solo.............................................................................. 53

4.3.1.1. Produção Relativa (PR) ...................................................... 53

4.3.1.2. Massa média dos frutos...................................................... 55

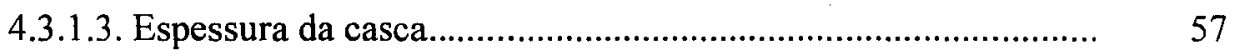

4.3.1.4. Rendimento de suco.............................................................. 58

4.3.1.5. Porcentagem de sólidos solúveis do suco (Brix)..................... 59

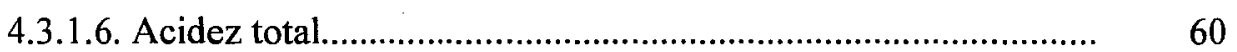

4.3.1.7. Relação sólidos solúveis/acidez................................................ 61

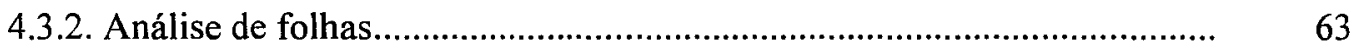

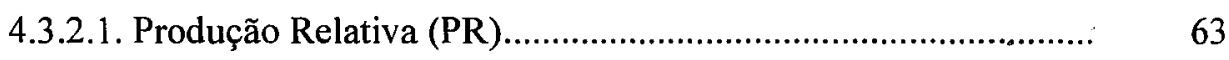

4.3.2.2. Massa média dos frutos.......................................................... 64

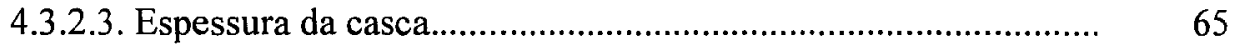

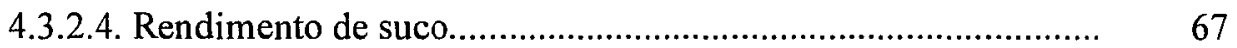

4.3.2.5. Porcentagem de sólidos solúveis do suco (Brix)...................... 68

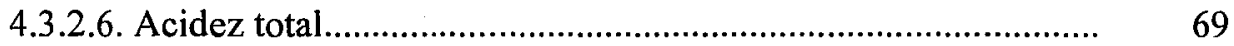

4.3.2.7. Relação sólidos solúveis/acidez........................................... 70

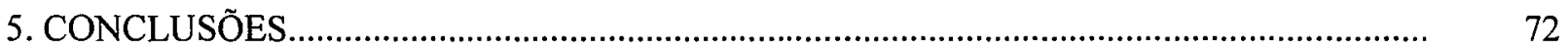

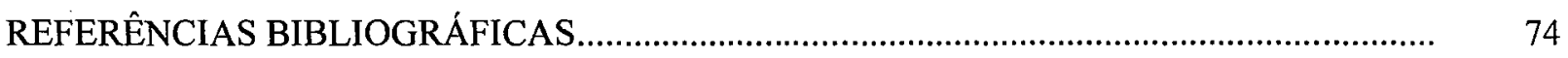

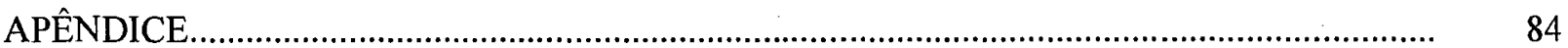




\title{
AVALIAÇÃO DA FERTILIDADE DO SOLO E DO ESTADO NUTRICIONAL DE POMARES DE LARANJEIRA VALÊNCIAE SUAS RELAÇÕES COM A PRODUTIVIDADE E A QUALIDADE DOS FRUTOS
}

\author{
Autor: ALBERTO CARLOS DE CAMPOS BERNARDI \\ Orientador: QUIRINO AUGUSTO DE CAMARGO CARMELLO
}

Resumo

O objetivo deste trabalho foi avaliar a fertilidade do solo e o estado nutricional de pomares de laranjeira 'Valência' (Citrus sinensis L. Osbeck) sobre limoeiro 'Cravo' (Citrus limonia L. Osbeck) e as relações desses fatores com a produtividade e a qualidade dos frutos.

Foram amostrados 30 pomares comerciais da região de Araraquara, Estado de São Paulo. As amostras de solo, para as avaliações granulométricas e químicas, foram coletadas em duas profundidades: de 0 a $20 \mathrm{~cm}$ e de 20 a $40 \mathrm{~cm}$ : As folhas foram amostradas em ramos frutíferos, coletando-se a $3^{\mathrm{a}}$. ou $4^{\mathrm{a}}$. folha do ramo com 6 a 7 meses de idade. Ambas as coletas foram realizadas no final do período chuvoso do ano de 1994.

$\mathrm{Na}$ coleta dos frutos, foi avaliada a produtividade, que foi transformada em produção relativa, para possibilitar a comparação entre os pomares de locais diferentes e com idades diferentes. Os parâmetros de qualidade analisados foram a massa média dos frutos, a espessura da casca, o rendimento de suco, os sólidos solúveis totais (brix), a acidez total e a relação sólidos solúveis/acidez .

A maior parte dos pomares está implantada em Latossolos Vermelho-Amarelo e VermelhoEscuro, sendo a textura predominante média. A avaliação da fertilidade do solo, pelas faixas de suficiência, mostrou que os teores de fósforo e magnésio, na maioria dos pomares estavam em níveis considerados de médio a alto; o potássio estava de baixo a médio; e a saturação por bases tinha valores de baixos até altos. $O$ boro no solo foi considerado adequado e o cobre e o zinco, nas duas profundidades, e o manganês na camada de 0 a $20 \mathrm{~cm}$ foram considerados altos. 
A avaliação do estado nutricional foi feita pelo uso do método convencional, das faixas de suficiência. Verificou-se que, em ordem decrescente, os nutrientes boro, zinco, potássio, nitrogênio e magnésio estavam adequados; cálcio, fósforo, manganês e enxofre, deficientes e, cobre e ferro, excessivos.

As relações entre a produtividade e a qualidade dos frutos com os parâmetros das análises de solo e de folha foram obtidas através de análises de regressão linear múltipla, utilizando o método do coeficiente de determinação $\left(\mathrm{R}^{2}\right)$ máximo. A seleção de variáveis para a análise de solo mostrou que as variáveis relativas à profundidade de $20 \mathrm{a} 40 \mathrm{~cm}$ foram mais frequientemente incluídas do que as variáveis da profundidade de 0 a $20 \mathrm{~cm}$. A seleção de variáveis para a análise de folha mostrou que, as relações entre os nutrientes são mais freqüentemente incluídas que os teores individuais. 


\title{
EVALUATION OF SOIL FERTILITY AND NUTRITIONAL STATUS OF 'VALENCIA' SWEET ORANGE ORCHARDS AND THEIR RELATIONSHIPS WITH YIELD AND FRUIT QUALITY
}

\author{
Author: ALBERTO CARLOS DE CAMPOS BERNARDI \\ Adviser: QUIRINO AUGUSTO DE CAMARGO CARMELLO
}

Summary

This research work had the objective to evaluate the soil fertility and the nutritional status of 'Valencia' sweet orange (Citrus sinensis L. Osbeck) budded on Rangpur lime (Citrus limonia L. Osbeck) and relate them with yield and fruit quality.

Samples were collected in commercial citrus orchards at Araraquara Region, São Paulo

State, Brazil. Soil samples, for physical and chemical analysis, were collected at two depths: 0 to 20 $\mathrm{cm}$ and 20 to $40 \mathrm{~cm}$. Leaf samples were collected from six to seven month old spring cycles from fruiting terminals. Soil and foliar samples were collected in March-April 1994.

Yield data was collected and transformed in Relative Production (\%), to allow comparison among different orchards in different sites, and different ages. The fruit quality parameters analyzed were fruit weight, peel thickness, juice percentage, total soluble solids, total acidity, and the ratio soluble solids/acidity.

Most of the orchards are over red yellow and dark red latossols, with a predominant loamy texture. Soil fertility evaluation by the sufficient range method showed that phosphorus and magnesium levels are medium to high; potassium is low to medium; and bases saturation is low to high in most orchards. Boron in soil was considered adequate, copper and zinc at two depths and manganese at 0 to $20 \mathrm{~cm}$ depths were high.

Evaluation of nutritional status was made by conventional procedure of sufficient range. The method showed that the adequate nutrients were, in decreased order: boron, zinc, potassium, nitrogen and magnesium. The deficient nutrients were calcium, phosphorus, manganese and sulphur. Copper ánd iron were in the excessive range. 
Relationships between productivity and fruit quality factors with soil and foliar analysis parameters were stablished throught the multiple linear regression. Variables related to 20 to $40 \mathrm{~cm}$ in depth for soil analysis included in the equation more frequently than variables related to 0 to 20 $\mathrm{cm}$ in depth. The selection of variables for foliar analysis showed that relations between nutrients were more frequently included in the equation than individual concentrations. 


\section{INTRODUÇÃO}

A citricultura do Estado de São Paulo, a maior do mundo em produção total atualmente, está implantada em solos de baixa fertilidade, como naqueles que anteriormente estavam sob vegetação de cerrado. Esses solos apresentam limitações químicas que comprometem o processo produtivo, tais como a elevada acidez, os baixos teores de fósforo disponível, de bases trocáveis $(\mathrm{K}$, $\mathrm{Ca}$ e $\mathrm{Mg}$ ) e de micronutrientes (B, Mn e $\mathrm{Zn}$ ), e a alta capacidade de fixação de fósforo. Diversos trabalhos têm mostrado porém, que podem ser alcançadas produtividades adequadas, com a remoção dessas limitações, através de calagem e adubações equilibradas, tanto na fase de formação como na fase de produção da cultura.

Um dos fatores que tem contribuído para a redução da produtividade dos pomares de citros é o desequilíbrio nutricional. De acordo com RODRIGUEZ (1991), nos pomares paulistas, as principais deficiências nutricionais são as dos macronutrientes nitrogênio, potássio e fósforo e as dos micronutrientes boro, manganês e zinco. A prática da calagem, visando a correção da acidez, fornece cálcio e magnésio, além de aumentar a disponibilidade do molibdênio. $O$ enxofre, aparentemente, não é problema na cultura, já que até hoje, não foram observados sintomas de deficiência no campo. $\mathrm{O}$ cloro é fornecido abundantemente, na forma de cloreto de potássio e, a 
utilização de fungicidas à base de cobre, para controlar a verrugose (Elsinoe fawcetti (Jenk.) Bit. e Jenk), supre as necessidades desse micronutriente.

O uso de análises de solo e de folhas permite avaliar o estado nutricional das culturas, indicar os nutrientes necessários para se atingir o equilíbrio nutricional, estabelecer as recomendações de adubação e monitorar sua eficiência. $\mathrm{O}$ fornecimento de nutrientes de forma equilibrada, é um dos fatores indispensáveis para a obtenção de altas produtividades com menores custos de produção.

As publicações existentes em relação à calibração da análise de solo e de folhas e produtividade, para a cultura dos citros, geralmente consideram os nutrientes isoladamente. Essas publicações são restritas no que se refere às interações entre os elementos. No entanto, situações bem definidas de desbalanço de um único nutriente, na prática, são difíceis de serem encontradas, por isso, o diagnóstico pelos métodos convencionais, muitas vezes, torna-se limitado. Existem contudo alternativas, para se avaliar o estado nutricional, de vários nutrientes ao mesmo tempo.

Este trabalho teve como objetivos, avaliar a fertilidade do solo e o estado nutricional de pomares de citros; correlacionar os teores de nutrientes no solo com a produtividade, os teores de nutrientes na planta com a produtividade e os teores de nutrientes no solo e na planta com a qualidade dos frutos. 


\section{REVISÃO DE LITERATURA}

\subsection{Avaliação da fertilidade do solo e do estado nutricional na cultura dos citros}

A análise de tecidos vegetais é baseada no princípio de que a concentração de um elemento ou nutriente na planta, ou em uma de suas partes, é resultado de todos os fatores que agiram e interagiram, afetando o crescimento da planta, incluindo a disponibilidade do elemento (MALAVOLTA et al., 1989). As folhas, como são a sede da maioria dos processos fisiológicos vegetais, geralmente são o órgão que melhor reflete o estado nutricional das plantas. As premissas da análise foliar são a existência de relações significativas entre o suprimento de nutriente e os teores deles nas folhas e que isso, por sua vez, está associado com produções.

A utilização da análise de folhas como uma ferramenta para avaliar o estado nutricional da cultura dos citros foi discutida por REUTHER \& SMITH (1954), SMITH (1966), CHAPMAN (1968), EMBLETON et al. (1973), e no Brasil por HIROCE (1984) e MALAVOLTA (1992). Os teores de nutrientes nas folha dos citros são afetados por vários fatores, tais como idade, tamanho e posição da folha na planta, presença ou não de frutos no ramo, carga de frutos na árvore, variedades enxerto e porta-enxerto, época do ano em que é feita a amostragem, clima, solo, irrigação, práticas 
culturais e adubação, conforme já foi destacado por REUTHER \& SMITH (1954), SMITH (1966), CHAPMAN (1968), EMBLETON et al. (1973), HIROCE (1984) e MALAVOLTA et al. (1992).

A fertilidade do solo procura estabelecer as relações entre o desenvolvimento das plantas e as propriedades do solo. No entanto, as relações são complexas pois a fertilidade do solo é o resultado da interação das propriedades químicas, físicas e biológicas do solo. A análise química de solo é reconhecida como sendo o melhor meio de avaliação da fertilidade do solo (TISDALE et al., 1985; RAIJ, 1991).

A análise de folhas integra os efeitos do solo, da planta, do clima e do manejo da cultura, dessa forma, ela é uma medida da disponibilidade dos nutrientes. No Brasil a recomendação é feita com base na análise de solo (CANTARELLA et al., 1992 e MALAVOLTA, 1992). A diagnose foliar pode ser muito útil, na avaliação dos efeitos de adubação com elementos muito móveis no solo, como o nitrogênio (MELSTED \& PECK, 1977). Na África do Sul, ela tem sido usada com sucesso, para a avaliação de nitrogênio e dos micronutrientes boro, ferro, manganês e zinco (DU PLESSIS, 1977).

No Brasil, a primeira contribuição ao estudo da diagnose foliar dos citros foi realizada por GALLO et al. (1960), onde foram analisadas folhas de laranjeira Baianinha. RODRIGUEZ \& GALLO (1961) e CAETANO et al. (1984), também no Brasil, não encontraram correlação entre a análise do solo e de folhas de citros. O mesmo ocorreu com ANDERSON \& ALBRIGO (1971) nos EUA. No entanto, QUAGGIO et al. (1992b) observaram correlação da análise de folhas para magnésio com a produção e o teor do nutriente no solo.

A função das análises de solo e de folha, é basicamente a de servir como base para a recomendação de adubação. Segundo MALAVOLTA (1995), algumas etapas devem ser cumpridas para a utilização das análises de solo e de folha nas recomendações de adubação, aumentando sua confiabilidade: 1) correlação: o método analítico deve discriminar solos que respondam muito, pouco ou medianamente à adição de fertilizantes ou a teores de nutrientes no solo; 2) calibração: teores baixos, médios ou altos encontrados no solo devem corresponder a colheitas baixas, médias ou altas; 3) recomendação: um número suficiente de ensaios de campo devem ser conduzidos para relacionar teores de nutrientes com adubação e colheita; 4) comprovação: as recomendações de 
adubação devem ser comprovadas com um número suficiente de ensaios no campo, em que se verifique uma razoável porcentagem de acerto entre o recomendado e o necessário. Ainda segundo o autor, antes da correlação, existe a amostragem, que deve ser padronizada nas mais diferentes variáveis para evitar erros. As etapas de correlação, calibração e recomendação podem ser cumpridas com dados de produção e teores foliares ou no solo obtidos diretamente no campo, sem recorrer-se à experimentação em parcelas ou canteiros.

\subsubsection{Calibração da análise de solo}

Para os solos arenosos e ácidos da Flórida, existe um certo número de trabalhos correlacionando a produção da cultura com a análise de solo para o fósforo, tornando possível a recomendação desse nutriente a partir da análise de solo. A análise de solo para a recomendação do potássio tem pouca eficiência, em função das perdas por lixiviação (Koo, $1984^{1}$, citado por CANTARELLA et al., 1992). Na África do Sul, a análise de solo vem sendo utilizada com sucesso na citricultura, existindo curvas de calibração para fósforo e potássio (DU PLESSIS, 1977).

No Brasil, as classes de interpretação de teores de nutrientes no solo para a citricultura foram inicialmente adaptadas de culturas anuais, quando então CANTARELLA et al. (1992), através da realização de experimentos de adubação NPK nas principais regiões citrícolas do Estado, obtiveram superficies de resposta específicas para a cultura. Através das equações obtidas, os autores calcularam as doses de adubação mais econômicas para os citros. Os autores observaram que as doses calculadas foram relativamente próximas àqueles anteriormente recomendados com base na análise de solo. Porém, em alguns casos, as doses de nitrogênio foram subestimadas e em solos deficientes em fósforo, as doses calculadas foram superiores às recomendadas antigamente. Os teores de fósforo e potássio na análise de solo correlacionaram-se bem com a produção de

${ }^{1}$ KOO, R.C.J. Recommended fertilizers and nutritional spray for citrus. Gainesville, Agricultural Experiment Stations - University of Florida, 1984.30p. (Bulletin 536D). 
frutos. Essas informações foram organizadas e estão disponíveis de maneira mais simplificada, na publicação do GRUPO PAULISTA DE ADUBAÇÃO E CALAGEM PARA CITROS (1994).

\subsubsection{Recomendação de adubação de citros no Brasil}

Apesar da importância da cultura dos citros no país e do efeito benéfico da utilização de fertilizantes na produção e na qualidade dos frutos, poucos estudos foram realizados até hoje no Brasil sobre a resposta dos citros às aplicações de adubos sob condições de campo. Atualmente, a recomendação de adubação é baseada em poucos resultados experimentais, nas produções esperadas e em informações empíricas obtidas em pomares comerciais.

Para CANTARELLA et al. (1992), as recomendações de adubação feitas para citros na Flórida, influenciaram as recomendações feitas no Brasil: Isso trouxe algumas distorções, especialmente com relação ao fósforo, pois os solos cultivados por um longo tempo com citros na Flórida, geralmente não respondem mais às aplicações desse elemento (Koo, $1984^{1}$, citado por CANTARELLA et al., 1992), enquanto que no Brasil, muitos solos são deficientes nesse nutriente.

O primeiro experimento conduzido com adubação NPK em São Paulo foi instalado em um Latossolo Vermelho-Escuro, com a laranja 'Baianinha' (Citrus sinensis L. Osbeck) sobre portaenxerto de laranjeira 'Caipira' (Citrus sinensis L. Osbeck), e que teve duração de 20 anos (RODRIGUEZ \& MOREIRA, 1969). O segundo foi conduzido em um Latossolo VermelhoAmarelo, com a laranjeira 'Hamlin' (Citrus sinensis L. Osbeck) sobre porta-enxerto de laranjeira 'Caipira', e foi conduzido por dez anos (RODRIGUEZ et al., 1973). Os resultados desses experimentos indicaram, que a laranjeiras responderam ao nitrogênio aplicado e que as respostas ao fósforo e ao potássio foram menores nas plantas acima dos 8 anos. As respostas a esses nutrientes, tornam-se mais freqüentes, porém não constantes. No caso do fósforo, as respostas observadas poderiam ser confundidas as com respostas ao cálcio, uma vez que a fonte de fósforo foi o superfosfato simples, além dos solos do experimento serem ácidos. Efeitos marcantes resultaram da aplicação anual de $40 \mathrm{kggha}^{-1}$ de nitrogênio, expressos por um aumento de $32 \%$ na produção, mas as 
doses maiores de nitrogênio não se refletiram em aumentos de produção de frutos (RODRIGUEZ \& MOREIRA, 1969).

Em um estudo de adubação de laranja 'Valência' (Citrus sinensis L. Osbeck) em um solo de baixa fertilidade do Sul do Brasil, realizado por GOEPFERT et al. (1987), as maiores produtividades foram obtidas com 100, 200 e $200 \mathrm{~kg} \cdot \mathrm{ha}^{-1}$ de $\mathrm{N}, \mathrm{P}_{2} \mathrm{O}_{5}$ e $\mathrm{K}_{2} \mathrm{O}$.

MALAVOLTA \& VIOLANTE NETTO (1988) relataram um efeito positivo e quadrático do enxofre, fornecido como sulfato de amônio, fosfogesso ou sulfato de potássio-magnésio, havendo um aumento significativo de $16 \%$ na produção obtida com o uso de $60 \mathrm{~kg}^{\mathrm{h}} \mathrm{ha}^{-1}$ de enxofre.

O estudo mais recente sobre a adubação de citros no Estado de São Paulo foi publicado por CANTARELLA et al. (1992). O experimento foi conduzido por 4 anos em pomares das regiões produtoras do Estado, com laranja sobre limoeiro 'Cravo' (Citrus limonia L. Osbeck). Os resultados mostraram que, o nitrogênio foi o nutriente que trouxe os maiores e mais freqüentes aumentos de produção. As respostas máximas de produtividade, de 26 a 48 t.ha $^{-1}$, foram obtidas com 20,140 e $210 \mathrm{~kg} \cdot \mathrm{ha}^{-1}$ de $\mathrm{N}, \mathrm{P}_{2} \mathrm{O}_{5}$ e $\mathrm{K}_{2} \mathrm{O}$, respectivamente.

\subsection{Levantamento do estado nutricional}

Os levantamentos do estado nutricional e da fertilidade do solo permitem avaliar as faixas de variação dos teores de nutrientes, dentro de faixas de suficiência previamente estabelecidas. As informações obtidas com esses levantamentos têm custos mais baixos e são obtidas mais rapidamente do que pelo estabelecimento de campos experimentais. Com esses resultados, é possível detectar-se áreas com desbalanços nutricionais e áreas para se realizarem estudos de problemas nutricionais específicos. Do ponto de vista prático, informações derivadas dos levantamentos podem ser transferidas imediatamente para os agricultores (CAETANO et al., 1984).

O primeiro levantamento nutricional de pomares de citros no Estado de São Paulo foi conduzido por RODRIGUEZ \& GALLO (1961). Nele foram amostrados o solo e as folhas de 40 pomares, observando-se uma alta porcentagem de ocorrência de deficiência nos teores foliares de magnésio e de zinco (em 65\% do total) e de fósforo (em 60\%). 
HIROCE (1984) apresentou os resultados de um levantamento realizado de 1963 a 1965, onde foram observadas altas porcentagens de ocorrência de deficiência de fósforo e de zinco (72,3 e $87 \%$, respectivamente) nos três anos de observação. O magnésio apresentou problemas no primeiro ano de estudo ( $62 \%$ de pomares deficientes) e o cálcio no segundo ano (100\% de deficiência) e de cobre no terceiro (61\%). No mesmo trabalho, também foi apresentado um outro levantamento, feito com os resultados de 1000 amostras de folhas enviadas pelos citricultores ao Instituto Agronômico, no periodo entre 1962 e 1983. As maiores porcentagens de ocorrência de deficiência observadas foram de boro e zinco ( $55 \%$ do total), seguidas pelas deficiências de fósforo, potássio, cálcio e magnésio ( $30 \%$ do total em média).

CAETANO et al. (1984) amostraram 40 pomares de laranja doce (Citrus sinensis L. Osbeck) das variedades 'Pera', 'Natal' e 'Valência', na região de Bebedouro, no período entre 1978 e 1982. Nos pomares com a variedade 'Valência' (C. sinensis), as deficiências observadas mais freqüentemente foram as de fósforo $(18,6 \%)$, potássio $(26,5 \%)$ e zinco $(65,3 \%)$. Para variedade 'Pera', as deficiências mais freqüentes foram as de magnésio $(37,8 \%)$ e boro $(62,2 \%)$. No total dos pomares, as deficiências de maior incidência foram as de zinco $(61,0 \%)$, boro $(58,3 \%)$ e de magnésio (31,8\%). Este estudo mostrou, que mesmo os pomares com produtividade relativamente elevada, mais que o dobro da média paulista, apresentaram problemas nutricionais, principalmente de potássio, magnésio e zinco.

Nos EUA, OBREZA (1990) realizou um levantamento nutricional, cobrindo 1400 ha de citros do sudeste da Flórida, por 4 anos. As análises de folhas revelaram que os teores de nitrogênio e fósforo estavam num nível ótimo ou alto, que os teores de cálcio e potássio foram geralmente mais baixos, e que o teor de magnésio foi mais baixo em pomares mais velhos, que apresentavam uma alta relação $\mathrm{Ca} / \mathrm{Mg}$. As análises de solo revelaram, que o grupo de pomares mais velhos, que possuiam $\mathrm{pH}$ adequado (sem necessidade de calagem) apresentaram os mais altos teores de fósforo, potássio, cálcio e magnésio disponíveis.

As deficiências mais freqüentes nos pomares paulistas, de acordo com os levantamentos realizados, podem ser classificadas, em ordem decrescente de ocorrência: zinco, fósforo, magnésio, boro, cálcio e potássio. Apesar de fornecerem informações úteis e prontamente utilizáveis, os 
levantamentos têm a eficiência limitada por não correlacionarem os teores foliares de nutrientes ou os teores de nutrientes no solo, com resultados de produção ou qualidade de frutos.

\subsection{Propriedades do solo}

A textura de um solo é definida pela proporção relativa entre as frações argila, silte ou areia no solo. HARDING \& CHAPMAN (1950), na California, mostraram que altas produtividades de citros podem ser obtidas, mesmo em solos que apresentam grande variabilidade na textura, na profundidade e no material de origem. A alta porcentagem de pomares encontrados pelos autores em solos argilo-arenosos, no entanto, sugeriu-lhes que, nesses solos, a obtenção de altas produtividades é mais fácil, ao contrário do que ocorreu em solos excessivamente arenosos ou argilosos. PLATT (1973) relatou também, que as plantas cítricas crescem bem em solos com ampla variação textural, porém ressaltou que os mais adequados são aqueles com textura média e verticalmente uniformes.

De acordo com RODRIGUEZ et al. (1977), os pomares de citros do Estado de São Paulo estavam, na sua maioria, sobre os solos: Podzólicos, nas variações Lins e Marília (originados de arenito calcário); Latossolos Vermelho-Escuro, fases arenosa e orto e Latossolos VermelhoAmarelo fase arenosa. Todos apresentam textura superficial arenosa a areno-argilosa, com excessão do LVA orto, que apresentava textura argilosa a argilo-arenosa.

A fração argila, que são as partículas de granulometria mais fina, têm natureza coloidal. Essas partículas finas ou coloidais, mais a matéria orgânica, têm alta atividade de superfície, tendo portanto um papel muito importante na atividade química do solo. A partir daí, originam-se as cargas, que regulam a capacidade de retenção de cátions, de água e de adsorção de fósforo, por exemplo. IBRAHIM (1978), trabalhando com as regressões múltiplas entre os parâmetros físicos e

químicos do solo e a produtividade de cana-de-açúcar no Sudão, observou que o conteúdo de argila foi o fator que mais influenciou na produtividade da cultura. 
BAR-AKIVA \& HAMOU (1974), em Israel, realizaram um experimento de adubação de laranjeira 'Valência' (C. sinensis), em dois tipos de solo, um com textura arenosa e outro com textura média. A composição mineral das folhas e as características de qualidade dos frutos diferiram significativamente nos dois solos, independentemente dos tratamentos com fertilizantes. As folhas das árvores cultivadas no solo franco argilo arenoso continham mais potássio e magnésio e menos cálcio e fósforo. DU PLESSIS \& KOEN (1984) observaram em solos argilosos com alta relação $\mathrm{Ca}+\mathrm{Mg} / \mathrm{K}$, que o potássio nas folhas era muito baixo, desse modo havia dificuldade para a obtenção de uma relação N/K ideal na planta.

SMITH (1966) reuniu vários trabalhos sobre os efeitos do $\mathrm{pH}$ sobre o desenvolvimento dos citros. As conclusões foram de que existe um efeito direto dos íon $\mathrm{H}^{+}$sobre o crescimento de plantas jovens de citros, principalmente sobre as raízes. Abaixo do $\mathrm{pH} 5,0$, o crescimento da parte aérea não é afetado, porém há uma redução do sistema radicular. Já abaixo do pH 4,0, existe uma redução do crescimento de todas as partes da planta, quando comparadas com outras cultivadas em pH 6,0. Por outro lado, CHAPMAN (1968), que também fez uma revisão sobre os efeitos do pH sobre o crescimento dos citros, relatou que eles desenvolvem-se adequadamente na ampla faixa de $\mathrm{pH}$ entre 3,8 até 9,7 .

MARTIN \& PAGE (1969), na California, observaram que plantas jovens de laranja cultivadas por 14 meses em vasos com solo, apresentaram redução no crescimento quando os solos possuiam baixo conteúdo de bases $(\mathrm{K}, \mathrm{Ca}, \mathrm{Mg})$ e o $\mathrm{pH}$ era inferior a 5,0. A redução no crescimento foi devida, à toxicidade provocada pelo excesso de íons $\mathrm{Al}^{3+}$ e ao baixo fornecimento de cálcio.

Os resultados de um experimento de longa duração, conduzido num solo arenoso e ácido da Flórida por ANDERSON (1971), mostraram a resposta da laranjeira 'Valência' (C. sinensis) sobre limoeiro 'Rugoso' (Citrus jambhiri, Lush.) à calagem. Os tratamentos consistiram na aplicação de calcários dolomítico e calcítico (com fornecimento de $\mathrm{Mg}$ ), elevando o $\mathrm{pH}$ ao valor 7,0, a testemunha possuia $\mathrm{pH}$ inicial igual a 5,2. Aos 7 anos de idade, a calagem proporcionou aumentos de $50 \%$ na produtividade, e no $15^{\circ}$. ano de experimentação, o incremento devido à calagem foi de $200 \%$, com uma produtividade de 8,1 caixas por planta. Não foram observadas diferenças entre os dois tipos de calcário utilizados. 
O teor de matéria orgânica no solo pode ser usado, dentro de certos limites, como uma estimativa do teor de nitrogênio total, pois em solos bem drenados a relação $\mathrm{C} / \mathrm{N}$ apresenta uma constância relativa. A relação é que o teor de nitrogênio é aproximadamente a vigésima parte do teor de matéria orgânica. Porém, a previsão do suprimento de nitrogênio a partir da matéria orgânica é difícil. A dificuldade está na avaliação de em qual estágio de degradação encontra-se a matéria orgânica. Na prática, pode ser admitida uma taxa de mineralização de $2 \%$ ao ano (RAIJ, 1991). No entanto, DASBERG (1987), revisou os resultados de experimentos com adubação nitrogenada nos citros realizados em Israel e no mundo e concluiu que, principalmente o nitrogênio originário da matéria orgânica do solo, e em menor quantidade o originário de reservas da própria árvore têm um papel importante no suprimento de nitrogênio para as partes vegetativas da árvore. $\mathrm{E}$ que esse fornecimento torna-se mais importante à medida que são reduzidas as adubações nitrogenadas.

MARTIN et al. (1953) utilizaram solos com diferentes relações entre cálcio, magnésio e potássio nos citros. Observaram forte antagonismo entre potássio e cálcio, e que havia redução no crescimento das plantas, quando o teor de potássio no solo era maior que 8,0\% da CTC. Quando esse teor era superior a $15 \%$, ocorria redução no crescimento da planta e queda de folhas, o que foi atribuído à menor absorção de cálcio. A relação $\mathrm{Ca} / \mathrm{Mg}$ foi pouco importante e os resultados mostram como os citros são exigentes em cálcio. HUNZIKER (1960) não conseguiu estabelecer um valor ótimo para o potássio trocável, aplicável a vários tipos de solo na Flórida, mas encontrou a melhor correlação entre a produção e a saturação de potássio no solo.

PRATT et al. (1957) estudaram o antagonismo entre magnésio e potássio em pomares na California. Um forte antagonismo foi observado entre os dois nutrientes e, para garantir-se níveis adequados de magnésio, a relação $\mathrm{K} / \mathrm{Mg}$ deve ser ao redor de $0,2: 1$ ou a relação $\mathrm{Mg} / \mathrm{K}$ de $5: 1$.

ALVA \& CHEN (1995) testaram seedlings de 2 porta-enxertos em diversas concentrações de cobre na solução nutritiva e observaram que o aumento da concentração externa de cobre levou à uma redução significativa no peso de material seco das raízes e da parte aérea e a uma diminuição na absorção principalmente de ferro e em menor intensidade de manganês e zinco. 


\subsection{Nutrição mineral dos citros}

Trabalhando no Brasil com laranjeira 'Baianinha' (C. sinensis), GALLO et al. (1960) observaram que, elevando-se a adubação potássica, houve elevação das concentrações foliares de nitrogênio e de potássio. $\mathrm{O}$ fósforo não foi alterado, porém o cálcio e o magnésio foram reduzidos, havendo um pronunciado antagonismo entre o potássio e o magnésio em condições de campo.

GALLO et al. (1966) observaram um efeito quadrático do nitrogênio sobre a produção e o teor foliar do nutriente, observaram também uma relação linear positiva entre o teor de cálcio nas folhas e a produção de frutos.

Um aumento significativo de $16 \%$ na produção de laranjeira 'Pera' (C. sinensis) sobre portaenxerto de limoeiro 'Cravo' (C. limonia), foi obtido por MALAVOLTA \& VIOLANTE NETTO (1988) com a aplicação de $60 \mathrm{~kg} \cdot \mathrm{ha}^{-1}$ de enxofre, associado com um teor de $0,275 \%$ de enxofre na folha. Os autores também relataram respostas à adição de micronutrientes (F.T.E.) em laranjeira 'Pera' sobre limoeiro 'Cravo'. Um ganho de produção de 19\% foi associado com um aumento no teor foliar de boro de 40 a 52 ppm e a produção aumentou $14 \%$, quando o zinco foliar aumentou de 16 para $20 \mathrm{ppm}$. Entretanto, EMBLETON et al. (1988), em um experimento de 4 anos com a laranjeira 'Navel' (Citrus sinensis L. Osbeck), não observaram aumentos de produtividade, quando compararam as plantas que não receberam pulverizações com aquelas que receberam manganês e zinco, provavelmente devido o uso contínuo desses nutrientes por anos seguidos.

Os experimentos de RODRIGUEZ \& MOREIRA (1969) e RODRIGUEZ et al. (1973) mostraram que a interação NP foi significante em experimentos de adubação NPK, com as laranjeiras 'Baianinha' (C. sinensis) e 'Hamlin' (C. sinensis), sobre laranjeira 'Caipira' (C. sinensis).

WEIR (1969) estudou as relaç̃̃es entre nitrogênio, potássio, cálcio e magnésio em laranjeiras, abordando o balanço nutricional. Observou que o potássio é o mais forte antagonista das três bases. A relação $\mathrm{N} / \mathrm{Ca}$ teve efeito significativo sobre os teores de potássio, porém não afetando os de magnésio. 
NAGAI et al. (1975), no Brasil, estudaram as relações entre os nutrientes dosados em folhas de café, citros e milho, em quatro tipos de solo, confirmando o antagonismo entre o potássio e o cálcio e entre o potássio e o magnésio. Cálcio e potássio mostraram antagonismo em folhas de café e sinergismo em folhas de citros. $\mathrm{O}$ nitrogênio e o fósforo tiveram efeito sinérgico em café e antagônico em citros. O fósforo correlacionou-se positivamente com o potássio nas três culturas. WALLACE (1990), utilizando resultados de um experimento de adubação NPK da literatura, discutiu as interações entre nitrogênio, fósforo e potássio nos citros. $O$ autor observou interações entre o potássio e o fósforo, e entre o potássio e o nitrogênio. $O$ potássio adicionado isoladamente aumentou a produção em $26 \%$, porém na presença de nitrogênio e fósforo, houve um aumento de $69 \%$.

REESE \& KOO (1975), na Flórida, em solos arenosos utilizaram laranjeira doce ( $C$. sinensis) com 5 anos das cultivares 'Hamlim', 'Pineapple' e 'Valência' em porta-enxerto de limoeiro 'Rugoso' (C. jambhiri), com quatro níveis de nitrogênio e potássio. $\mathrm{O}$ aumento na superfície foliar observado foi relacionado com as aplicações de nitrogênio, mas não com as de potássio. As análises foliares mostraram que o aumento nas aplicações de nitrogênio, resultou em aumento nos teores foliares de nitrogênio e magnésio, porém menores teores de fósforo e potássio. Os aumentos de potássio estavam associados com altos teores de fósforo e potássio, mas menores de cálcio e magnésio.

KOO \& REESE (1977), nos EUA, estudaram a influência da fertilidade do solo e da irrigação em condições de campo, nas análises de solo e de folhas de laranjeira 'Temple' (Citrus reticulata X C. sinensis) sobre tangerineira 'Cleópatra' (Citrus aurantium L.), com doses crescentes de nitrogênio e potássio (67-304 kg.ha ${ }^{-1} \mathrm{~N}$ e 56-253 kg.ha $\left.{ }^{-1} \mathrm{~K}_{2} \mathrm{O}\right)$ e $127 \mathrm{~kg} \cdot \mathrm{ha}^{-1} \mathrm{P}_{2} \mathrm{O}_{5}$. Após seis anos de resultados, observaram que houve aumento de produção, na maior parte dos anos, com o aumento das dosagens de nitrogênio e potássio. A adição de fósforo também aumentou a produção. quando comparada com o tratamento sem fósforo. $O$ nitrogênio fornecido resultou em concentrações foliares maiores de nitrogênio e de magnésio, reduzindo o fósforo, o potássio e o cálcio. As aplicações de fósforo aumentaram as concentrações de fósforo, potássio e cálcio e reduziram as de magnésio. 
As relações entre os teores foliares de nutrientes têm se mostrado muitas vezes, mais significativas na correlação com a produtividade e com efeitos na qualidade dos frutos, do que com os teores individuais dos nutrientes. WEIR (1969) utilizou, em estudos de nutrição dos citros, o conceito do Balanço Nutricional, proposto por Shear $^{2}$ et al. (1948). Segundo o autor, o crescimento vegetal é função de dois fatores da nutrição: a intensidade e o balanço. Enquanto o balanço de nutrientes pode ser avaliado diretamente pela composição das folhas, a intensidade da nutrição deve levar em conta, além dos teores foliares, a produção.

SMITH (1966) resumiu algumas das interações observadas na época, resultados de diversos trabalhos da literatura sobre experimentos de adubação realizados na Flórida. Posteriormente, EMBLETON et al. (1978), apresentaram novas relações baseadas nas anteriores e acrescidas de resultados experimentais conduzidos na California. Algumas dessas relações diferiram de um trabalho para o outro.

DU PLESSIS \& KOEN (1988) verificaram em um experimento de adubação NK com laranjeiras 'Valência' (C. sinensis), que a relação $\mathrm{N} / \mathrm{K}$ nas folhas foi mais importante na determinação da produtividade e do tamanho dos frutos, que os teores individuais de $\mathrm{N} \mathrm{e} \mathrm{K}$.

MALAVOLTA (1992) apresentou os resultados de 2 experimentos fatoriais conduzidos durante 2 anos com as laranjas 'Natal' (C. sinensis) e 'Pera' (C. sinensis), nos quais não foram observadas relações significativas entre os níveis individuais de nutrientes e a produção. Correlações estreitas entretanto, foram observadas quando foram usadas as relações $\mathrm{N} / \mathrm{K} \mathrm{e} \mathrm{Ca} / \mathrm{K}$.

\subsection{Niveis críticos e faixas adequadas}

O nível crítico de um nutriente é definido como a concentração necessária desse nutriente para a obtenção de crescimento, produção ou qualidade "ótimas", assumindo-se que nenhum outro fator seja limitante ou "sub-ótimo" (ULRICH \& HILLS, 1967). O "ótimo" é definido como o teor

${ }^{2}$ SHEAR, C.B.; CRANE, H.L.; MYERS, A.T. Nutrient-elemente balance: application of the concept to the interpretation of foliar analysis. Proceedigs of American Society for Horticultural Science, College Park, 51: 319-26, 1948. 
de um nutriente no vegetal "necessário para se ter 90 ou $95 \%$ do crescimento, da produção, ou da qualidade máxima", ou como a "concentração de nutrientes na qual o crescimento da planta começa a declinar", ou ainda "o menor teor de um nutriente associado com a maior produção" (TISDALE et al., 1985). Para SUMNER (1979) o nível crítico é o teor de um nutriente na planta, amostrado em um determinado estádio de crescimento, no qual ocorre uma redução de 5 a $10 \%$ no rendimento. Geralmente, a definição mais utilizada é a de que nível crítico é aquele teor de nutriente associado a $90 \%$ da produção máxima. DOW \& ROBERTS (1982) propuseram para o nível crítico não um ponto, mas uma faixa crítica de teores de um nutriente, acima da qual a planta é amplamente suprida e abaixo dela ocorre deficiência do nutriente.

Desse modo, a interpretação dos teores individuais dos nutrientes em faixas aumenta a segurança da interpretação e também permite a observação da evolução do estado nutricional, ou da fertilidade do solo, com o passar do tempo. Esse seria um passo adiante na interpretação pelo nível crítico, e deve ser considerado que há uma relação entre a interpretação em faixas para solos e folhas (RAIJ, 1991).

RAIJ (1974) utilizou os resultados de três culturas (feijão, algodão e cana-de-açúcar), para estabelecer os limites das classes de teores de fósforo e potássio no solo, que se relacionam com produção relativa como sendo: a) classe de teores muito baixos, que corresponde a uma faixa de $0 \mathrm{a}$ $70 \%$ de produção relativa; b) teores baixos, de 70 a $90 \%$; c) teores médios, de 90 a $100 \%$; d) teores altos, correspondem à produção máxima; e) teores muito altos, correspondem ao dobro do limite inferior da classe de teores altos.

O GRUPO PAULISTA DE ADUBAÇÃO E CALAGEM PARA CITROS (1994) propôs uma tabela com os limites de classes de teores no solo para fósforo, potássio, magnésio e saturação por bases, como sendo: alto, médio, baixo e muito baixo. Apesar de ainda não haver no Brasil uma concordância nos métodos de análise para micronutrientes, os autores propuseram uma tabela com os limites das classes, para os micronutrientes boro, cobre, ferro, manganês e zinco do solo, além do enxofre. 
Diversos trabalhos estabeleceram as faixas adequadas dos nutrientes nas folhas de citros (REUTHER \& SMITH, 1954; CHAPMAN, 1968; SMITH, 1966 e EMBLETON et al., 1973). RODRIGUEZ (1991) associou essas informações aos seus resultados de pesquisa sobre a nutrição dos citros no Brasil e elaborou uma tabela com a classificação dos limites dos teores de nutrientes para a cultura. A mais recente contribuição para faixas adequadas de nutrientes na folha para o Estado de São Paulo foi publicada pelo GRUPO PAULISTA DE ADUBAÇÃO E CALAGEM DOS CITROS (1994). REUTHER \& SMITH (1954) que, nos EUA, foram os primeiros a estabelecer padrões de nutrientes nas folhas dos citros, propuseram as faixas: deficiente, baixo, ótimo, alto e excessivo. O GRUPO PAULISTA PARA ADUBAÇÃO E CALAGEM DOS CITROS (1994) propõe três faixas para os foliares de nutrientes: baixo, adequado e excessivo.

\subsection{Nutrição mineral e qualidade dos frutos cítricos}

Existem ainda divergências na literatura com relação ao efeito dos nutrientes na composição e na qualidade dos frutos. Variáveis tais como clima, práticas culturais, controle de doenças, reguladores vegetais, variedades de copa e de porta-enxertos provavelmente interferem nas respostas das plantas em termos de qualidade dos frutos.

O efeito de um certo elemento na composição e na qualidade dos frutos é determinado indiretamente, comparando-se um fruto produzido na presença do nutriente com outro produzido na ausência deste. Isto não é totalmente correto, já que as interações com outros elementos deveriam ser consideradas. Além disso, existem várias intensidades de deficiência de um certo elemento, como pode ser demonstrado pela análise de folha (REUTHER \& SMITH, 1954).

SMITH (1966) observou que a qualidade dos frutos é influenciada pela aplicação de fertilizantes, mas também por fatores climáticos, tais como temperatura, chuvas, insolação e por fatores culturais, tais como porta-enxerto, irrigação e espaçamento. EMBLETON et al. (1975) alertaram que o efeito dos nutrientes sobre a qualidade dos frutos será observado somente, se a disponibilidade do nutriente no solo não for elevada. 
O tamanho do fruto é reduzido, geralmente, pelo aumento do nível de nitrogênio na planta e isso pode ocorrer em função do aumento do número de frutos e da produção em resposta ao nutriente (REUTHER \& SMITH, 1952). GALLO et al. (1966), no Brasil, confirmaram essa observação, quando obtiveram um efeito quadrático das doses de nitrogênio sobre a produção e o teor foliar do nutriente, acompanhado, entretanto, por uma diminuição no peso do fruto.

Uma diversidade de respostas pode ser observada com relação ao efeito dos teores de nitrogênio sobre a concentração de sólidos solúveis do suco. Quando o teor desse nutriente na planta é alto, existe a tendência de aumento suave da acidez titulável do suco (REUTHER \& SMITH, 1952), e de ter-se um pequeno decréscimo sobre os teores de sólidos solúveis totais. Esse efeito, faz com que haja uma redução na relação sólidos solúveis/acidez (ratio), retardando a maturação.

Segundo STEWART \& WHEATON (1965), o efeito do nitrogênio sobre os sólidos solúveis totais do suco é positivo porém, para REITZ \& KOO (1960), o efeito é negativo. REESE \& KOO (1975), em solos arenosos da Flórida, utilizaram plantas com 5 anos das cultivares 'Hamlim', 'Pineapple' e 'Valência' em porta-enxerto de limoeiro 'Rugoso' (C. jambhiri), com quatro níveis de nitrogênio e potássio e observaram que altas doses de nitrogênio aumentaram a produção de frutos e os teores de sólidos solúveis totais.

REITZ \& KOO (1960) observaram que, altos teores de nitrogênio e potássio aumentaram a acidez dos frutos da laranjeira 'Valência' (C. sinensis). Não houve diferenças significativas no conteúdo de suco, pelo efeito desses nutrientes, mas foram observadas diferenças significativas na relação sólidos solúveis/acidez, onde aplicou-se pequenas doses de nitrogênio e potássio. Os autores observaram também, a ocorrência de uma desordem fisiológica da casca, o creasing, em frutos de casca fina, que receberam pequenas doses de potássio num ano e altas doses de nitrogênio no ano seguinte.

Existem interações entre o nitrogênio e o potássio nas plantas cítricas que afetam a qualidade dos frutos. REUTHER \& SMITH (1952) observaram que os frutos da laranjeira 'Valência' (C. sinensis) provenientes das parcelas com altos teores de potássio, retiveram mais a coloração verde que os frutos das parcelas com baixos teores de potássio. E que o esverdeamento 
era adicional, quando estavam associadas às altas doses de nitrogênio e de potássio. REITZ \& KOO (1960) relataram que. as doses mais altas de nitrogênio reduziram significativamente o tamanho dos frutos. No entanto, as aplicações de potássio nao tiveram nenhum efeito sobre o tamanho dos frutos. Quanto ao peso dos frutos, ele foi reduzido signicativamente com o aumento nos teores de nitrogênio, e aumentado quando aumentou-se as doses de potássio. Altas doses de nitrogênio foram associadas ao esverdeamento e a defeitos na casca dos frutos, 'enquanto as doses de potássio tiveram pequeno efeito. DU PLESSIS \& KOEN (1988) estabeleceram limites da relação N/K para a obtenção de produção máxima ou tamanho de frutos ótimo, uma vez que eles são inversamente relacionados. Concluíram que, o potássio estando num nível adequado, a produção será máxima se o teor de nitrogênio for elevado, porém os frutos com tamanho mais próximos de um tamanho ótimo são obtidos quando o teor desse nutriente é relativamente mais baixo.

Tanto a aparência externa do fruto, como a composição interna, são afetadas pelo nivel de nutrição de potássio. O potássio exerceu uma forte influência positiva sobre o tamanho dos frutos nos anos em que todos frutos foram pequenos (PARKER \& JONES, 1950). Com o aumento do potássio, aumentam a espessura da casca e sua aspereza. Altos teores de potássio produziram frutos pouco coloridos, mais esverdeados. $\mathrm{O}$ efeito mais consistente do aumento de potássio sobre a composição do suco é reduzir a relação sólidos solúveis/acidez. Isto ocorre, em função da diminuição nos sólidos ou do aumento nos ácidos, sendo o último mais freqüente (REUTHER \& SMITH, 1952 e EMBLETON et al., 1956).

Segundo JONES (1961), o fósforo tem grande influência sobre a qualidade dos frutos, mesmo quando nenhum aumento na produção é observado. $\mathrm{O}$ efeito mais marcante do nutriente porém, é observado nas plantas deficientes. CHAPMAN (1968) considerou que a deficiência de fósforo provocou a produção de frutos grandes, relacionando-os à diminuição do número de frutos, que também foi observada nessas condições. EMBLETON et al. (1975) também relataram a redução do tamanho dos frutos, quando altos teores de fósforo estão presentes. ANDERSON (1966) não observou efeito do fósforo sobre o tamanho dos frutos. 
SMITH et al (1949) e EMBLETON et al. (1975) observaram que os acréscimos no nível de fósforo, estavam associados às reduções na espessura da casca, porém apenas EMBLETON et al. (1975) observaram que, o aumento da porcentagem de suco estava relacionado com o aumento no teor de fósforo.

SMITH et al. (1949) e EMBLETON et al. (1956) demonstraram os efeitos do fósforo sobre a redução da acidez do suco. Os sólidos solúveis, quando afetados, foram reduzidos suavemente, mas apesar disso, a relação sólidos solúveis/acidez foi aumentada consistentemente. $O$ nutriente ainda tendeu a diminuir a espessura da casca e a aumentar a porcentagem de suco no fruto. $\mathrm{O}$ ácido ascórbico foi reduzido pelo fósforo.

A elevação do teor de fósforo na planta reduziu a percentagem de acidez do suco, e também os sólidos solúveis, segundo SMITH et al. (1949), ANDERSON (1966) e REESE \& KOO (1975). De acordo com EMBLETON et al. (1975), um acréscimo no fósforo, embora provoque uma diminuição nos sólidos solúveis e na acidez do suco, aumenta a relação sólidos solúveis/acidez mostrando, na verdade, uma ação eficaz do fósforo sobre a redução da acidez.

WEIR et al. (1978), em um experimento fatorial de adubação NPK em laranjeira 'Valência' (C. sinensis), observaram que quando a dọse de nitrogênio era alta e a de fósforo era baixa, ocorriam frutos deformados, com a casca espessa e rugosa. A acidez total do suco diminuiu com as doses de fósforo, confirmando os trabalhos anteriores. A porcentagem de suco aumentou linearmente com as doses de fósforo e de potássio, e foi reduzida com o aumento nas doses de nitrogênio.

SMITH \& RASMUSSEN (1959) realizaram estudos com laranjeira 'Valência' (C. sinensis), cultivada em soluções nutritivas, e verificaram que as variações nos níveis de cálcio não tiveram efeitos consistentes em nenhum dos aspectos de qualidade dos frutos estudados, tais como: peso do fruto, espessura da casca, percentagem de suco, sólidos solúveis e acidez, e relação sólidos solúveis/acidez. ANDERSON (1971), trabalhando com calagem em citros, verificou o efeito do $\mathrm{pH}$ e do cálcio sobre a qualidade dos frutos, com acréscimos na porcentagem de suco, sólidos solúveis e do ratio e decréscimo na acidez na acidez. 
REUTHER \& SMITH (1952) não observaram nenhum efeito da aplicação de magnésio em laranjeira 'Valência' (C. sinensis). Os teores foliares observados desse nutriente ficaram entre $0,17 \mathrm{e}$ $0,41 \%$. Os autores concluíram que, o efeito de um certo nutriente sobre os constituintes do suco serão observados num nível nutricional mais baixo, e que os efeitos ficam menos evidentes num nível nutricional mais elevado. No Brasil, QUAGGIO et al. (1992a), em um experimento de calagem em laranjeira 'Valência' ( $C$. sinensis), observaram que o aumento das doses de calcário dolomítico provocaram aumentos lineares nos sólidos solúveis e na acidez do fruto, além dos teores de magnésio na folha.

Há poucos trabalhos sobre a influência dos micronutrientes sobre a qualidade dos frutos cítricos. Se os micronutrientes estão disponíveis em quantidades suficientes para manter a produção, eles terão pequeno efeito sobre a qualidade dos frutos, porém, se os níveis forem baixos e afetarem a produção, seus efeitos sobre os frutos poderão ser notados.

SMITH (1955) relatou que o ácido cítrico e a vitamina $\mathrm{C}$ do suco decresciam suavemente com o aumento dos teores de boro. Segundo JONES (1961), as plantas de laranjeira 'Valência' ( $C$. sinensis) deficientes neste nutriente, apresentaram um espessamento do albedo, surgindo uma descoloração amarronzada e a formação de goma. A polpa ficou seca e continha muito pouco suco.

Segundo JONES (1961), os citros são muito sensíveis ao cobre e, é possível passar-se da deficiência ao excesso com uma pulverização. O excesso de cobre é capaz de diminuir o crescimento e induzir a clorose por deficiência de ferro, nas plantas. Ainda segundo esse autor, existem relatos de que o excesso de cobre pode elevar a acidez total do fruto.

Um aumento no teor de sólidos solúveis do suco foi associado à aplicações de manganês nos citros (ROY, 1955). LABANAUSKAS et al. (1963) observaram que as pulverizações com manganês em plantas com deficiências leves, aumentaram a produção de frutos e os sólidos solúveis do suco. EMBLETON et al. (1988) em um experimento com laranjeira 'Navel' ( $C$. sinensis), observaram que mesmo os tratamentos que receberam manganês via foliar, apresentaram frutos pequenos e alta ocorrência de creasing, porém o suco apresentou relação sólidos solúveis/acidez e teor de vitamina $\mathrm{C}$ mais elevados que o tratamento sem o nutriente. 
JONES (1961), citando outros autores, relatou que a deficiência de zinco em citros é a mais comum entre os micronutrientes. Os relatos quanto à associação entre a deficiência do micronutriente e a qualidade do fruto são divergentes. Alguns da Flórida, associam a deficiência de zinco à ocorrência de frutos pequenos com casca fina e outros, da California, à ocorrência de frutos pequenos com casca grossa. LABANAUSKAS et al. (1963) observaram que pulverizações com zinco, em plantas levemente deficientes nesse nutriente, não afetaram a produção de frutos, aumentando a porcentagem de ácido ascórbico e reduzindo a porcentagem de suco. LANGTHASA \& BHATTACHARYYA (1991), na Índia, observaram que as pulverizações com zinco a 0,4\%, tanto na forma quelatizada como na forma de sulfato, em limoeiros aumentou a porcentagem de suco, de sólidos solúveis e de ácido ascórbico.

Os tipos de solo e suas características físicas também podem interferir na qualidade dos frutos cítricos. BAR-AKIVA \& HAMOU (1974) observaram em um experimento de adubação com laranjeira 'Valência' (C. sinensis), realizado em um solo arenoso e em um solo de textura média, que a qualidade dos frutos diferiu significativamente entre nos dois solos, independentemente dos tratamentos com fertilizantes. Os frutos no solo com textura média foram grandes, com casca grossa, contendo mais ácidos totais e vitamina $\mathrm{C}$ no suco e foram menos afetados por uma desordem da casca (creasing).

\subsection{Produção relativa (PR\%)}

O conceito de produção relativa ou porcentagem de suficiência tem sido muito usado em calibrações de resultados de análise de solo. Pode ser calculada como (RAIJ, 1991):

Produção relativa $(\%)=($ Prod. sem o nutriente $/$ Prod. com o nutriente $) \times 100$

De acordo com TISDALE et al. (1985), o conceito de produção relativa é que a produção final é o produto dos fatores envolvidos e não a resultante de um fator mínimo, como no caso da aplicação da Lei do Mínimo. Assim, se dois nutrientes no solo tiverem potencial para produzirem determinadas porcentagens da produção máxima, a produção final, se eles não forem aplicados, será o produto das porcentagens individuais (RAIJ, 1991). Contudo, o autor adverte, que como no 
caso das leis do mínimo e dos incrementos decrescente, não se deve esperar uma aplicação rigorosa desse conceito.

O conceito de produção relativa vem sendo muito utilizado desde o trabalho de Bray $(1948)^{3}$, citado por RAIJ (1992), que estabeleceu uma curva de calibração de potássio trocável, no solo, para respostas da cultura do milho em ensaios de adubação. As correlações obtidas em curvas de calibração, com produções relativas, são pouco ou menos influenciadas por fatores edáficos, climáticos e até de manejo (MELSTED \& PECK, 1977), enquanto que as produções absolutas não se correlacionam bem com os resultados de análise de solo. RAIJ (1974) mostrou que, com a utilização desse conceito, foi possível agrupar culturas diferentes (cana-de-açúcar, feijão e algodão) numa curva de calibração de potássio, obtendo ainda um coeficiente de correlação de 0,762 .

MALAVOLTA (1992) utilizou os resultados de produção relativa de 2 experimentos fatoriais conduzidos durante 2 anos com as laranjeiras 'Natal' (C. sinensis) e 'Pera' (C. sinensis), nos quais observou correlações significativas entre PR e as relações $\mathrm{N}: \mathrm{K}$ e Ca:K.

Apesar dos aspectos positivos apontados, existem críticas ao uso de produções relativas, pelo fato de não permitirem interpretações diretas, em termos de quantidades de nutrientes a aplicar, ou avaliações econômicas (NELSON \& ANDERSON, 1977). A produção relativa porém, somente é utilizada para estabelecer faixas de teores ou o nível crítico, e não é usada na análise econômica, que é feita reunindo resultados experimentais dentro de agrupamentos a partir da análise de solo (RAIJ, 1991).

\subsection{Regressão linear múltipla}

Em ciência usam-se constantemente modelos determinísticos e modelos probabilísticos para a explicação dos fenômenos observados. Os probabilísticos são os modelos aplicados nas ciências biológicas, em razão da natureza dos fenômenos estudados. Segundo ALVAREZ (1994), em

${ }^{3}$ BRAY, R.M. Correlation of soil tests with crop responses to added fertilizers and with fertilizer requirements. In: KITCHEN, H.B., ed. Diagnostic tecniches for soil and crops. Washington, American Potash Institute, 1948. p.53-86. 
virtude do grande número de fatores que influenciam nos fenômenos biológicos, não é possível trabalhar com todos eles em conjunto. Então, a alternativa é limitar o número de parâmetros em estudo $\left(\mathrm{X}_{\mathrm{p}}\right)$, controlar outros $\left(\mathrm{X}_{\mathrm{c}}\right)$ e deixar outros atuarem livremente $\left(\mathrm{X}_{1}\right)$. Assim, as observações que dependem da ação conjunta de inúmeros fatores, podem ser representadas da seguinte forma:

$$
\mathrm{Y}=\mathrm{f}\left(\beta_{\mathrm{n}} \mathrm{X}_{\mathrm{p}} \mid \mathrm{X}_{\mathrm{c}}, \mathrm{X}_{1}\right)+\varepsilon_{\mathrm{pcl}}
$$

onde, $\beta_{\mathrm{n}}$ são um conjunto de parâmetros relacionados com $\mathrm{X}_{\mathrm{p}}$ e $\varepsilon_{\mathrm{pcl}}$ é o componente aleatório que depende dos fatores em estudo, dos controlados e dos que atuam livremente.

A análise de regressão, uma das ferramentas estatísticas mais amplamente utilizadas na elaboração de equações empíricas, com aplicações nos mais diversos ramos da ciência, consiste de um conjunto de técnicas para o estudo do relacionamento entre variáveis, de grande interesse teórico e também prático pela metodologia relativamente simples (MATTIOLLI, 1983). Esta ferramenta vem sendo utilizada em trabalhos nos quais se procura relacionar a produtividade de uma cultura com os teores de nutrientes ou propriedades do solo. Vários procedimentos vem sendo propostos para a seleção do melhor modelo matemático capaz de relacionar essas variáveis. RAIJ (1992) apresentou uma revisão sobre os modelos matemáticos mais utilizados em estudos de fertilidade do solo. Além dos modelos utilizados em curvas de resposta, que descrevem as relações entre um nutriente e a produção, existem as funções de produção ou superfícies de resposta, onde são feitas avaliações conjunta do efeito de vários nutrientes sobre a produção. Segundo ALVAREZ (1994) em função do grande número de fatores em estudo $\left(X_{p}\right.$, para $\left.p=1,2, \ldots, n\right)$, as superfícies de resposta apresentam diferentes figuras geométricas para apresentar suas respostas: a) com quatro ou mais fatores tem-se um hipercubo de resposta; b) com três fatores têm-se um cubo de resposta; c) com dois fatores tem-se uma superfície de resposta, que é um corte no cubo de resposta e, d) com um só fator tem-se uma curva de resposta, que é a representação de um corte na superfície de resposta. GOMES \& ZEN (1995) salientaram que a equação obtida através de regressões, somente deverá ser utilizada dentro dos limites das variáveis para as quais foi calculada. Uma vez que a extrapolação poderá levar a resultados errôneos. 
As relações entre mais de uma variável independente com produção podem ser obtidas através de modelos de regressão linear múltipla. Geralmente um modelo desse tipo pode ser descrito como:

$$
Y=\beta_{0}+\beta_{1} x_{1}+\beta_{2} x_{2}+\ldots+\beta_{n} x_{p}+\varepsilon_{n p}
$$

onde, $Y$ é a variável dependente; $\beta_{0}, \beta_{1}, \beta_{2}, \ldots, \beta_{p}$ são os coeficientes de regressão. As variáveis independentes são $\mathrm{x}_{1}, \mathrm{x}_{2}, \ldots, \mathrm{x}_{\mathrm{p}}$. $\mathrm{O}$ índice $\mathrm{p}$ é o número de parâmetros usados para determinação do modelo e, $\varepsilon_{\mathrm{np}}$ é o componente aleatório.

Existem diferentes métodos para se calcular a regressão linear múltipla. MATTIOLLI (1983) recomendou o procedimento "todas equações possíveis", que tem o inconveniente de apresentar muitas equações para a análise final, mas confere maior precisão ao modelo. Outra metodologia, o procedimento backward, parte de uma equação completa, com todas as variáveis independentes e passa a eliminar as variáveis com significância abaixo de um valor preestabelecido (HOCKING, 1976). O procedimento forward é o inverso do anterior, inicia com a equação com apenas uma variável mais significativa no modelo e acrescenta outras variáveis ao modelo uma a uma, iniciando pela variável que promover um decréscimo mais significativo na soma de quadrados do resíduo, e que apresente um nível de significância do valor $\mathrm{F}$ menor que um valor prédeterminado (HOCKING, 1976). O procedimento stepwise é um aprimoramento da regressão forward, pois permite que a cada inclusão de uma nova variável, se avalie as variáveis do modelo segundo a significância de cada uma. Dessa maneira pode-se eliminar uma variável que já esteja no modelo, ao contrário do forward, pois nele, uma vez que a variável esteja no modelo ela não é mais eliminada. Outro procedimento ainda é o do coeficiente de determinação máximo (" $\mathrm{R}^{2}$ máximo"), no qual não se determina apenas um modelo como nos anteriores. Ao invés disso, o método determina o modelo com uma variável que apresente o maior $\mathrm{R}^{2}$, o modelo com duas variáveis e maior $\mathrm{R}^{2}$ e assim sucessivamente. Para cada comparação o método determina se removermos uma variável e substituirmos por outra, há um aumento do $\mathrm{R}^{2}$. Feitas todas as combinações possíveis dentro de cada sub-conjunto de resultados, o modelo apresentado é a combinação que produz o maior $\mathrm{R}^{2}$. A diferença do $\mathrm{R}^{2}$ máximo com o stepwise é que no primeiro todas as combinações entre as variáveis são sempre avaliadas antes que alguma alteração seja feita, no stepwise a variável 
removida não retorna ao modelo, sem considerar que a combinação com uma outra, no caso de haver interação entre elas, poderia melhorar o modelo (SAS INSTITUTE, 1989).

Para a escolha do melhor modelo existem diferentes métodos, sendo os mais utilizados: a) a comparação entre as somas de quadrados dos desvios das regressões, quanto menor a soma melhor a equação obtida; b) a comparação dos quadrados médios dos resíduos, quanto menor o valor, melhor a equação; c) o $\mathrm{R}^{2}$, a melhor equação é a que apresenta o valor mais alto; e d) o $\mathrm{R}^{2}$ estimado ou ajustado (PIMENTEL-GOMES, 1982), ocorre o mesmo que para o $\mathrm{R}^{2}$. Porém segundo PIMENTEL-GOMES (1982) a equação escolhida deverá apresentar, na análise de variância, os Graus de Liberdade do Resíduo maiores que 10.

MATTIOLLI (1983) comparou os métodos de seleção de equações de regressão linear múltipla, e concluiu que o procedimento "todas as regressões possíveis" foi o mais indicado para se obter a melhor estimativa de perdas de grãos armazenados. LAIRD \& CADY (1969) em seu estudo com experimentos de fertilização, também compararam métodos e encontraram melhores resultados com a utilização do procedimento stepwise. CARMELLO (1991) usou os métodos stepwise e forward para selecionar variáveis do solo e da planta (diagnose foliar) que melhor explicassem a variação da produtividade de milho e amendoim. BEAUCLAIR (1991) utilizou o procedimento stepwise, para relacionar produtividade da cana-de-açúcar com algumas propriedades químicas de solo reveladas pelas análises de amostras de terra. BEAUCLAIR (1994) também utilizou este método para relacionar, além da produtividade de cana-de-açúcar, os teores de nutrientes no caldo com as propriedades químicas do solo.

Os modelos matemáticos ou as funções de produção podem correlacionar além das doses de nutrientes, parâmetros da análise de solo e outras variáveis. IBRAHIM (1978), trabalhando com cana-de-açúcar no Sudão, relacionou a produtividade da cultura com parâmetros físicos e químicos do solo. PAULER \& NEUMANN (1989) também relacionaram resultados experimentais de trigo com parâmetros físicos e químicos do solo. GOMES \& ZEN (1995) estudaram a produtividade de eucalipto em função de variáveis químicas e físicas do solo. A partir de 84 variáveis, de 4 profundidades do solo, obtiveram uma equação linear com 25 variáveis das 2 primeiras camadas do 
solo, combinando os métodos das Variáveis Canônicas com o método de regressão múltipla do $\mathrm{R}^{2}$ máximo.

ANDERSON \& ALBRIGO (1971), na Flórida, utilizaram as regressões simples e múltipla em amostras de solo e folhas que receberam calagem regularmente, com o objetivo de determinar as características do solo que melhor explicassem os teores de $\mathrm{Ca}$ e $\mathrm{Mg}$ nas folhas de citros. Não foram observadas correlações diretas entre os teores de $\mathrm{Ca}$ e $\mathrm{Mg}$ no solo, extraídos com acetato de amônio, tanto com o pH ajustado em 7,0 como em 4,8. O teor de $\mathrm{Mg}$ nas folhas foi melhor explicado através da regressão múltipla utilizando-se como variáveis independentes o $\mathrm{pH}$, o teor do nutriente e a relação $\mathrm{Ca} / \mathrm{Mg}$.

CANTARELLA et al. (1992), com o objetivo de estabelecer relações quantitativas entre produção de frutos cítricos e adubação NPK, ajustaram superfícies de respostas aos resultados de experimentos fatoriais incompletos. As funções foram ajustadas aos locais dos experimentos e foram calculadas as doses de nutrientes necessárias para máximas produções física e econômica. 


\section{MATERIAL E MÉTODOS}

O presente trabalho foi realizado na Região de Araraquara, Estado de São Paulo, nos municípios de Araraquara, Nova Europa e Boa Esperança do Sul, entre os paralelos $21^{\circ} 48^{\prime} \mathrm{S}$ e $22^{\circ} \mathrm{S}$ e os meridianos $48^{\circ} 10^{\prime} \mathrm{Gw}$ e $48^{0} 31^{\prime} \mathrm{Gw}$.

\subsection{Clima}

O clima da região, de acordo com a classificação internacional de Koeppen, é do tipo Cwa, um clima mesotérmico com inverno seco. $\mathrm{O}$ índice de pluviosidade varia de $1100 \mathrm{a} 1700 \mathrm{~mm}$ por ano, sendo que o mês mais chuvoso oscila entre janeiro e fevereiro e a estação seca ocorre entre os meses de abril e setembro, sendo julho, o mês mais seco, quando o total de chuvas não ultrapassa $30 \mathrm{~mm}$. A temperatura média do mês mais quente varia entre 22 e $24^{\circ} \mathrm{C}$, e a do mês mais frio apresenta valores inferiores a $18^{\circ} \mathrm{C}$ (BRASIL, 1960).

Devido à ausência de um posto agrometerológico que fornecesse as normais climatológicas específicas para Araraquara, optou-se pelos dados da Estação Experimental de Jaú, do Instituto Agronômico de Campinas (IAC), devido à proximidade dessa com a região em que foi realizado o 
estudo. A tabela 1, fornecida pela Seção de Climatologia Agrícola do IAC, apresenta as temperaturas mensais máximas e mínimas $\left({ }^{0} \mathrm{C}\right)$ e a precipitação pluviométrica mensal $(\mathrm{mm})$ para o período do estudo e as médias do período entre 1961 e 1990 para efeito de comparação.

Tabela 1: Temperaturas $\left({ }^{\circ} \mathrm{C}\right)$ máximas, mínimas e quantidade de chuva $(\mathrm{mm})$ para o período de 1961 a 1990 e para o ano agrícola de 1993/94.

\begin{tabular}{cccc|ccc}
\hline \multirow{2}{*}{ mês } & \multicolumn{3}{c|}{ Médias de 1961 a 1990 } & \multicolumn{3}{c}{ Ano agrícola 1993/94 } \\
\cline { 2 - 7 } & T max & T min & Chuva & T max & T min & Chuva \\
\hline set & 28,2 & 15,0 & 67,7 & 26,6 & 15,6 & 179,9 \\
out & 28,9 & 16,5 & 123,8 & 27,7 & 17,9 & 44,1 \\
nov & 29,3 & 17,6 & 149,3 & 28,4 & 19,1 & 149,0 \\
dez & 28,9 & 18,7 & 247,7 & 29,1 & 19,7 & 191,3 \\
jan & 29,6 & 19,3 & 230,6 & 29,1 & 19,5 & 199,8 \\
fev & 29,9 & 19,5 & 204,9 & 31,6 & 20,8 & 129,4 \\
mar & 29,7 & 18,8 & 145,6 & 28,7 & 18,8 & 216,1 \\
abril & 28,1 & 16,7 & 75,0 & 28,2 & 17,2 & 58,1 \\
maio & 26,0 & 14,1 & 63,9 & 26,4 & 15,4 & 29,0 \\
jun & 25,0 & 12,6 & 49,1 & 24,9 & 11,6 & 27,5 \\
jul & 25,3 & 12,3 & 33,5 & 26,4 & 12,4 & 19,3 \\
ago & 27,4 & 12,3 & 30,5 & 28,4 & 12,4 & 0,0 \\
\hline ano & 28,0 & 16,2 & 1421,5 & 28,0 & 16,7 & 1243,5 \\
\hline
\end{tabular}

\subsection{Material de origem e solos}

O estudo foi realizado na região central do Estado de São Paulo, na região fisiográfica do Planalto Central, sub-região do Alto Planalto. Segundo o antigo Serviço Nacional de Levantamento 
e Conservação do Solo (SNLCS), em BRASIL (1960), na região encontram-se basicamente 2 tipos de material de origem: a) rochas eruptivas básicas, representadas por basalitos, basaltos e diabásios, que originam o latossolo roxo, a terra roxa estruturada e o litossolo; b) arenitos, sub-divididos em Arenito Bauru com cimentação calcárea (que origina o latossolo vermelho escuro - fase arenosa) e o Arenito Botucatu (que originam os solo latossolo vermelho amarelo - fase arenosa, regosolo, "integrade" para latossolo vermelho amarelo e para podzólico vermelho amarelo).

\subsection{Variedades Copa e Porta-enxerto}

A variedade copa ou enxerto utilizada no estudo foi a laranjeira 'Valência' (Citrus sinensis (L.) Osbeck). O porta-enxerto das plantas foi o limoeiro 'Cravo' (Citrus limonia (L.) Osbeck).

\subsection{Histórico e agrupamento dos pomares}

As amostras utilizadas no estudo foram coletadas em 5 propriedades. Cada amostra foi coletada e representou um pomar, num total de 30 amostras, representando 30 pomares. Os pomares foram definidos como sendo unidades homogêneas dentro das propriedades quanto à época de plantio, ao tipo de solo e aos tratos culturais. Como haviam variações de uma propriedade para outra, quanto ao espaçamento, tipo de solo e a idade da cultura, as amostras foram subdivididas em 7 grupos homogêneos quanto a essas variáveis (tabela 2).

O controle de plantas daninhas nas propridades é feito com a aplicação de herbicidas nas linhas e roçadeira nas entrelinhas. Nas propriedades utiliza-se o Manejo Integrado de Pragas (MIP).

Todos os pomares receberam adubações no ano agrícola 1993/94, sem que se fizesse calagem nos mesmos. Na adubação via solo foram utilizadas formulações NPK, as dosagens foram variáveis em função do manejo adotado nas propriedades. Foram feitas aplicações foliares com micronutrientes em todos os pomares. Alguns receberam ainda adubação orgânica. As formulações e as quantidades aplicadas, assim como alguns detalhes sobre essa prática, estão na tabela 3. 
Tabela 2: Classe de solo, número de plantas por hectare e no total por talhão, produtividade absoluta e produção relativa dos talhões em função dos grupos de amostras para o espaçamento da cultura e a idade.

\begin{tabular}{|c|c|c|c|c|c|c|c|c|}
\hline \multirow{2}{*}{$\begin{array}{l}\mathrm{N}^{0} \cdot \mathrm{da} \\
\text { amostra }\end{array}$} & \multirow[t]{2}{*}{ Grupo } & \multirow[t]{2}{*}{ Solo } & \multirow{2}{*}{$\begin{array}{c}\text { Espaçamento } \\
\text { (m) }\end{array}$} & \multicolumn{2}{|c|}{$\mathbf{N}^{0}$. de plantas } & \multirow{2}{*}{$\begin{array}{l}\text { Idade } \\
\text { (anos) }\end{array}$} & \multirow{2}{*}{$\begin{array}{c}\text { Produtividade } \\
\left(\mathrm{t}_{\mathrm{hha}} \mathbf{p}^{-1}\right)\end{array}$} & \multirow{2}{*}{$\begin{array}{l}\text { PR } \\
\text { (\%) }\end{array}$} \\
\hline & & & & por ha & total & & & \\
\hline 1 & 1 & $\mathrm{TE}$ & $7,5 \times 4,5$ & 296 & 811 & 18 & 37,756 & 100,00 \\
\hline 2 & 1 & $\mathrm{TE}$ & $7,5 \times 4,5$ & 296 & 764 & 18 & 37,376 & 98,99 \\
\hline 3 & 1 & $\mathrm{TE}$ & $7,5 \times 4,5$ & 296 & 770 & 16 & 34,632 & 91,73 \\
\hline 4 & 1 & $\mathrm{TE}$ & $7,5 \times 4,5$ & 296 & 512 & 16 & 29,613 & 78,43 \\
\hline 5 & 2 & $\mathrm{LA}_{\mathrm{m} \text { ar }}$ & $7,0 \times 4,0$ & 357 & 3619 & 5 & 7,050 & 100,00 \\
\hline 6 & 2 & $\mathrm{LA}_{\mathrm{mar}}$ & $7,0 \times 4,0$ & 357 & 4081 & 5 & 6,810 & 96,60 \\
\hline 7 & 2 & $\mathrm{LA}_{\mathrm{m} \text { ar }}$ & $7,0 \times 4,0$ & 357 & 3894 & 5 & 6,047 & 85,77 \\
\hline 8 & 2 & $L A_{m a r}$ & $7,0 \times 4,0$ & 357 & 3704 & 5 & 5,518 & 78,30 \\
\hline 9 & 2 & $\mathrm{LA}_{\mathrm{mar}}$ & $7,0 \times 4,0$ & 357 & 3455 & 5 & 4,678 & 66,36 \\
\hline 10 & 2 & $\mathrm{LA}_{\mathrm{mar}}$ & $7,0 \times 4,0$ & 357 & 5000 & 5 & 4,261 & 60,44 \\
\hline 11 & 2 & $\mathrm{LA}_{\mathrm{mar}}$ & $7,0 \times 4,0$ & 357 & 2800 & 5 & 2,724 & 58,64 \\
\hline 12 & 3 & $\mathrm{LA}_{\mathrm{m} \text { ar }}$ & $7,0 \times 6,0$ & 238 & 1200 & 7 & 14,794 & 100,00 \\
\hline 13 & 3 & $\mathrm{LA}_{\mathrm{mar}}$ & $7,0 \times 6,0$ & 238 & 1200 & 7 & 12,234 & 82,70 \\
\hline 14 & 3 & $\mathrm{LA}_{\mathrm{mar}}$ & $7,0 \times 6,0$ & 238 & 1200 & 7 & 11,537 & 77,98 \\
\hline 15 & 4 & LE & $7,5 \times 4,0$ & 333 & 3183 & 6 & 16,528 & 100,00 \\
\hline 16 & 4 & LE & $7,5 \times 4,0$ & 333 & 1660 & 6 & 16,189 & 97,95 \\
\hline 17 & 5 & LE & $7,5 \times 4,0$ & 333 & 5200 & 10 & 60,595 & 100,00 \\
\hline 18 & 5 & LE & $7,5 \times 4,0$ & 333 & 1320 & 7 & 54,287 & 89,59 \\
\hline 19 & 5 & LE & $7,5 \times 4,0$ & 333 & 1323 & 7 & 53,323 & 88,00 \\
\hline 20 & 5 & LE & $7,5 \times 4,0$ & 333 & 710 & 15 & 48,840 & 80,96 \\
\hline 21 & 5 & LE & $7,5 \times 4,0$ & 333 & 3550 & 10 & 47,755 & 78,51 \\
\hline 22 & 5 & LE & $7,5 \times 4,0$ & 333 & 1200 & 15 & 28,365 & 46,81 \\
\hline 23 & 5 & LE & $7,5 \times 4,0$ & 333 & 2223 & 15 & 14,579 & 24,06 \\
\hline
\end{tabular}


Tabela 2: Classe de solo, número de plantas por hectare e no total por talhão, produtividade absoluta e produção relativa dos talhões em função dos grupos de amostras para o espaçamento da cultura e a idade (continuação).

\begin{tabular}{|c|c|c|c|c|c|c|c|c|}
\hline \multirow{2}{*}{$\begin{array}{l}\mathbf{N}^{0} \text {. da } \\
\text { amostra }\end{array}$} & \multirow[t]{2}{*}{ Grupo } & \multirow[t]{2}{*}{ Solo } & \multirow{2}{*}{$\begin{array}{c}\text { Espaçamento } \\
\text { (m) }\end{array}$} & \multicolumn{2}{|c|}{$\mathbf{N}^{\mathbf{0}} \cdot$ plantas } & \multirow{2}{*}{$\begin{array}{l}\text { Idade } \\
\text { (anos) }\end{array}$} & \multirow{2}{*}{$\begin{array}{c}\text { Produtividade } \\
\left(\text { t.ha }^{-1}\right)\end{array}$} & \multirow{2}{*}{$\begin{array}{l}\text { PR } \\
(\%)\end{array}$} \\
\hline & & & & por ha & total & & & \\
\hline 24 & 6 & $\mathrm{LA}_{\mathrm{m} 2}$ & $7,5 \times 6,0$ & 222 & 1100 & 14 & 35,049 & 100,00 \\
\hline 25 & 6 & $\mathrm{LA}_{\mathrm{m} 2}$ & $7,5 \times 6,0$ & 222 & 550 & 14 & 28,103 & 80,18 \\
\hline 26 & 6 & $\mathrm{LA}_{\mathrm{m} 2}$ & $7,5 \times 6,0$ & 222 & 820 & 11 & 21,920 & 62,54 \\
\hline 27 & 7 & $\mathrm{LA}_{\mathrm{m} 1}$ & $7,0 \times 6,0$ & 222 & 764 & 26 & 42,955 & 100,00 \\
\hline 28 & 7 & $\mathrm{LA}_{\mathrm{m} 1}$ & $7,0 \times 6,0$ & 222 & 746 & 26 & 40,472 & 94,23 \\
\hline 29 & 7 & $\mathrm{LA}_{\mathrm{m} 1}$ & $7,0 \times 6,0$ & 222 & 837 & 27 & 26,350 & 61,34 \\
\hline 30 & 7 & $\mathrm{LA}_{\mathrm{m} 1}$ & $7,0 \times 6,0$ & 222 & 661 & 27 & 20480 & 47,68 \\
\hline
\end{tabular}

Tabela 3: Adubações, via solo e foliares, utilizadas nas áreas representadas pelos grupos de amostras, no ano agrícola 1993/94.

\begin{tabular}{|c|c|c|c|}
\hline \multirow{2}{*}{$\begin{array}{l}\text { Grupo de } \\
\text { amostras }\end{array}$} & \multicolumn{2}{|r|}{ Adubação } & \multirow{2}{*}{ Observaçōes } \\
\hline & $\begin{array}{c}\text { formulação } \mathrm{N}: \mathrm{P}_{2} \mathrm{O}_{5}: \mathrm{K}_{2} \mathrm{O} \\
\text { (por planta) }\end{array}$ & foliar (em 2000 l) & \\
\hline 1 & $\begin{array}{l}2 \mathrm{~kg} \text { de } 3: 15: 15 \\
\quad+0,5 \mathrm{Zn}\end{array}$ & $\begin{array}{c}8 \mathrm{~kg} \mathrm{ZnSO}_{4} \\
\text { uréia }\end{array}$ & $\begin{array}{l}\text { foram feitas } 2 \text { aplicações } \\
\text { foliares }\end{array}$ \\
\hline 2 & $1,2 \mathrm{~kg}$ de $19: 10: 19$ & $\underset{\text { uréia }}{6 \mathrm{~kg} \mathrm{ZnSO}_{4}}+\underset{1,5 \mathrm{~kg} \mathrm{H}_{3} \mathrm{BO}_{4}}{+0,4 \% \mathrm{de}}$ & fonte de $\mathrm{N}=$ Nitrocálcio \\
\hline 3 & $2,4 \mathrm{~kg} \mathrm{19:10:19}$ & $\underset{\text { uréia }}{6 \mathrm{~kg} \mathrm{ZnSO}_{4}}+\underset{\mathrm{Kg} \mathrm{H}_{3} \mathrm{BO}_{4}}{1,0,5 \% \mathrm{de}}$ & fonte de $\mathrm{N}=\mathrm{NH}_{4} \mathrm{NO}_{3}$ \\
\hline 4 & $1,5 \mathrm{~kg}$ de $19: 10: 19$ & $6 \mathrm{~kg} \mathrm{ZnSO}_{4}+\underset{\text { uréia }}{1,5 \mathrm{~kg} \mathrm{H}_{3} \mathrm{BO}_{4}+0,5 \% \text { de }}$ & $\begin{array}{l}4 \text { kg.planta }{ }^{-1} \text { de cama de } \\
\text { frango }\end{array}$ \\
\hline 5 & $3,5 \mathrm{~kg}$ de $19: 10: 19$ & $\begin{array}{c}6 \mathrm{~kg} \mathrm{ZnSO}+1,5 \mathrm{~kg} \mathrm{H}_{3} \mathrm{BO}_{4}+4 \mathrm{~kg} \\
\mathrm{MnSO}_{4}+0,5 \% \text { de uréia }\end{array}$ & $\begin{array}{l}6 \mathrm{~kg} \cdot \mathrm{planta} \mathrm{a}^{-1} \text { de cama de } \\
\text { frango }\end{array}$ \\
\hline 6 & 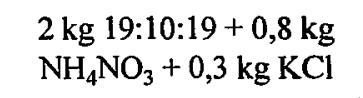 & $6 \mathrm{~kg} \mathrm{ZnSO}_{4}+\underset{\text { uréia }}{1,5 \mathrm{~kg} \mathrm{H}_{3} \mathrm{BO}_{4}}+0,4 \% \mathrm{de}$ & fonte de $\mathrm{N}=\mathrm{NH}_{4} \mathrm{NO}_{3}$ \\
\hline 7 & $2 \mathrm{~kg} 3: 15: 15+0,5 \mathrm{Zn}$ & $\underset{\text { uréia }}{8 \mathrm{~kg} \mathrm{ZnSO}_{4}}+\underset{3 \mathrm{BO}_{4}}{1,5 \mathrm{~kg} \mathrm{H}_{1} \mathrm{BO}}+0,35 \%$ de & 2 aplicações foliares \\
\hline
\end{tabular}

* Cada tanque de 2000 l pulverizou aproximadamente 130 plantas. 


\subsection{Amostragem de solo, folhas e frutos}

A amostragem tanto de folhas como do solo seguiu as recomendações do GRUPO PAULISTA DE ADUBAÇÃO E CALAGEM PARA CITROS (1994). Ambas foram realizadas nos meses de março e abril de 1994.

$\mathrm{Na}$ amostragem de folhas foram coletadas aproximadamente 100 por talhão, coletando-se de cada planta, a $3^{\text {a }}$ ou a $4^{\text {a }}$ folha geradas na primavera de 1993 , num total de 4 , nos 4 quadrantes. $\mathrm{Na}$ época da amostragem, as folhas tinham entre 6 e 7 meses de idade, em ramos com frutos de 2 a $4 \mathrm{~cm}$. Esses ramos estavam situados a cerca de 1,20 a 1,80m acima do solo.

A amostragem de solo foi feita nas camadas de 0 a $20 \mathrm{~cm}$ e de 20 a $40 \mathrm{~cm}$ de profundidade, retirando-se aproximadamente 20 subamostras de cada talhão, abrangendo toda a faixa de adubação, na região de projeção da copa das árvores. A ferramenta utilizada na amostragem foi o trado tipo sonda da marca "Sondaterra", da Bravifer Indústria de Equipamentos e Assessoria Agronômica.

Os frutos, para as avaliações de produção e análise tecnológica, foram amostrados entre o final de agosto e o início de setembro de 1994. Para se avaliar a produtividade foram colhidos os frutos de 5 plantas por talhão e o valor dessa massa foi multiplicado pelo número de plantas por hectare. Para a análise qualitativa foram amostrados 4 frutos por planta, nos 4 quadrantes, de aproximadamente 15 plantas por talhão.

\subsection{Análises químicas do solo}

O preparo das amostras, as extrações e as determinações analíticas foram realizados no Laboratório de Análise de Solo do Setor de Nutrição Mineral de Plantas, do Departamento de Química da Escola Superior de Agricultura "Luiz de Queiroz", seguindo a metodologia proposta por RAIJ \& QUAGGIO (1983). 
As amostras, contendo aproximadamente $300 \mathrm{~cm}^{3}$ de terra, foram homogeneizadas e secas em estufa com circulação forçada de ar, em temperatura inferior a $40^{\circ} \mathrm{C}$ e em seguida foram passadas por peneira com $2 \mathrm{~mm}$ de malha.

A determinação da matéria orgânica foi feita utilizando dicromato de sódio em ácido sulfúrico; a extração do fósforo, cálcio, magnésio e potássio foi feita através da resina trocadora de íons e o alumínio trocável foi extraído com $\mathrm{KCl} 1 \mathrm{~N}$ a $\mathrm{pH} 7,0$. Para a extração dos micronutrientes cobre, ferro, manganês e zinco foi utilizado o extrator DTPA-TEA e para o boro o extrator água quente.

$\mathrm{O}$ pH foi determinado diretamente com um potenciômetro em uma suspensão de solo em cloreto de cálcio $0,01 \mathrm{M}$. O fósforo foi determinado por espectrofotometria, o potássio por fotometria de chama, o cálcio e o magnésio por espectrofotometria de absorção atômica, a acidez titulável pelo método SMP e para o alumínio trocável foi feita a determinação titulométrica com hidróxido de sódio $0,02 \mathrm{~N}$. Os micronutrientes cobre, ferro, manganês e zinco foram determinados por espectrofotometria de absorção atômica.

A partir dessas análises, obtiveram-se então os resultados expressos em: matéria-orgânica

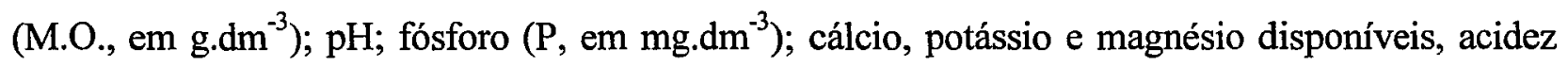
potencial e alumínio trocável $\left(\mathrm{Ca}, \mathrm{K} \mathrm{e} \mathrm{Mg}, \mathrm{H}+\mathrm{Al}\right.$ e $\mathrm{Al}^{3+}$, respectivamente, em $\left.\mathrm{mmol}_{\mathrm{c}} \cdot \mathrm{dm}^{-3}\right)$; boro, cobre, ferro, manganês e zinco $\left(\mathrm{B}, \mathrm{Cu}, \mathrm{Fe}, \mathrm{Mn}\right.$ e $\mathrm{Zn}$, respectivamente, em $\left.\mathrm{mg} \cdot \mathrm{dm}^{-3}\right)$. Em seguida calculou-se a somatória de bases (SB); capacidade de troca de cátions (CTC); saturação por bases (V\%); saturação por alumínio ( $\mathrm{m} \%$ ); porcentagem de cálcio, potássio e magnésio na capacidade de troca de cátions $\left(\mathrm{Ca}_{\mathrm{CTC}}, \mathrm{K}_{\mathrm{CTC}}\right.$ e $\mathrm{Mg}_{\mathrm{CTC}}$, respectivamente) e as relações cálcio por potássio $(\mathrm{Ca} / \mathrm{K})$, magnésio por potássio $(\mathrm{Mg} / \mathrm{K})$ e cálcio por magnésio $(\mathrm{Ca} / \mathrm{Mg})$.

\subsection{Análises granulométricas do solo}

O preparo das amostras e as determinações foram realizadas no Laboratório de Física do Solo do Departamento de Ciência do Solo da Escola Superior de Agricultura "Luiz de Queiroz". A 
metodologia utilizada foi a de KIEHL (1979). A partir dessas análises obtiveram-se os teores de: argila, silte e areia (em g. $\left.\mathrm{kg}^{-1}\right)$.

As classes texturais são dadas, pelo sistema classificatório de maior uso, através das 3 variáveis: somatório das areias, silte e argila, representadas graficamente de forma triangular. As classes texturais são a intersecção dos teores das 3 variáveis. Desse método existem duas variações, uma que fornece divisões mais detalhadas e uma outra, derivada dessa, mais generalizada, que é utilizada geralmente em levantamentos de solos para distinguir unidades amplas de mapeamento (OLIVEIRA et al., 1992). Como o objetivo do trabalho não era classificação exata dos solos, optouse pela apresentação dos solos em estudo no sistema contendo apenas cinco agrupamentos texturais: arenosa, média, argilosa, muito argilosa e siltosa.

A classificação dos solos foi obtida baseada em BRASIL (1960) e OLIVEIRA et al. (1992), além das observações feitas no campo.

\subsection{Análises químicas das folhas}

O preparo das amostras, a obtenção dos extratos e as determinações analíticas foram realizadas no Laboratório de Análise de Plantas do Setor de Nutrição Mineral de Plantas, do Departamento de Química da Escola Superior de Agricultura "Luiz de Queiroz".

No preparo, o material vegetal fresco foi lavado em água destilada contendo detergente. Em seguida foi enxaguado com água desmineralizada e colocado sobre uma superfície plástica limpa para secar ao ar. As amostras foram então colocadas em sacos de papel e postas a secar em

estufa com circulação forçada de ar, com a temperatura variando entre 60 e $70^{\circ} \mathrm{C}$, até atingir peso constante. A moagem foi feita em moinho tipo Wiley, passando-se as amostras por peneiras com 20 mesh ou malha de $1 \mathrm{~mm}$.

A obtenção dos extratos seguiu a metodologia descrita por SARRUGE \& HAAG (1974). As extrações foram feitas por digestão ácida a quente ou por decomposição por via seca. A digestão sulfúrica foi utilizada para a obtenção do extrato para a determinação do nitrogênio. A digestão nítrico-perclórica foi utilizada para a obtenção dos extratos para as determinações de fósforo, 
potássio, cálcio, magnésio, enxofre, cobre, ferro, manganês e zinco e a incineração foi utilizada para o boro.

O nitrogênio foi determinado pelo método semi-micro-Kjeldahl; fósforo por colorimetria de vanadato molibdato; potássio por fotometria de chama; cálcio, magnésio, enxofre, cobre, ferro, manganês e zinco por espectrofotometria de absorção atômica e boro por colorimetria de azometina H.

A partir das análises obtiveram-se resultados dos teores de nitrogênio, fósforo, potássio, cálcio, magnésio e enxofre (N, P, K, Ca, Mg, S, respectivamente, em g. $\mathrm{kg}^{-1}$ ) e de boro, cobre, ferro, manganês e zinco ( $\mathrm{B}, \mathrm{Cu}, \mathrm{Fe}, \mathrm{Mn}, \mathrm{Zn}$, respectivamente, em mg.kg ${ }^{-1}$ ). Em seguida calculou-se o quadrado dos teores e todas as relações entre os nutrientes.

\subsection{Análises tecnológicas dos frutos}

As análises tecnológicas constaram de análises físicas e químicas do fruto e do suco. Tomou-se uma sub-amostra de 20 frutos da amostragem feita no campo. Foi então determinado a massa média dos frutos (g). A espessura média da casca ( $\mathrm{mm})$, incluindo o albedo, foi obtida com um paquímetro e tomando-se 6 medidas por fruto. O suco foi extraído com um espremedor elétrico e quantificado para obter-se o rendimento de suco (\%).

As análises químicas do suco foram feitas de acordo com a metodologia da ASSOCIATION OF OFFICIAL ANALYTICAL CHEMISTS (AOAC, 1990). Avaliou-se a acidez titulável total (\%), por titulação de uma alíquota do suco com $\mathrm{NaOH} 0,1 \mathrm{~N}$. A porcentagem de sólidos solúveis (Brix, em \%) foi medida por refratometria. A relação sólidos solúveis/acidez total (Ratio) foi então calculada.

\subsection{Produção Relativa (\%)}

A apresentação da produtividade foi feita em termos de Produção Relativa (PR). Desse modo, as amostras foram reunidas em grupos homogêneos quanto ao tipo de solo, espaçamento e a 
idade. Dentro de cada grupo, a amostra com maior produtividade absoluta foi considerada aquela com $100 \%$ de $\mathrm{PR}$, as demais foram calculadas em função dessa primeira. A tabela 2 apresenta os grupos de amostras em função dos espaçamentos da cultura, idade, número de plantas por hectare e por talhão, as produtividades por hectare $\left(\mathrm{t} \cdot \mathrm{ha}^{-1}\right)$ e as produções relativas (\%).

\subsection{Análises Estatísticas}

Dos resultados obtidos foram calculados, segụndo GOMES (1982), o desvio padrão e o coeficiente de variação (CV\%) e foram ainda selecionados os valores máximos e mínimos observados. Foram feitas distribuições de frequências para as observações referentes à fertilidade do solo e ao estado nutricional dos pomares. Os limites das classes foram aqueles estabelecidos pelo GRUPO PAULISTA DE ADUBAÇÃO E CALAGEM PARA CITROS (1994).

Foram feitas análises de regressão entre os resultados de: a) produção relativa e os teores de nutrientes na folha; b) produção relativa e os parâmetros físicos e químicos do solo; c) parâmetros tecnológicos dos frutos e teores de nutrientes na folha e; d) parâmetros tecnológicos dos frutos e parâmetros físicos e químicos do solo.

A correlação entre as variáveis independentes (os parâmetros físicos e químicos do solo e teores de nutrientes na planta) com as variáveis dependentes (produção relativa e parâmetros tecnológicos dos frutos) foi feita através da regressão linear múltipla, utilizando-se o método do $\mathrm{R}^{2}$ máximo. Foi utilizado o PROC REG com opção SELECTION=MAXR, do pacote estatístico SAS (SAS INSTITUTE, 1989). As equações escolhidas foram aquelas que apresentaram os maiores $\mathrm{R}^{2} \mathrm{e}$

$\mathrm{R}^{2}$ ajustado, o menor quadrado médio do resíduo (QMR), porém que apresentaram Graus de Liberdade do Resíduo maior que 10. 


\section{RESULTADOS E DISCUSSÃO}

\subsection{Análise química do solo}

Nas tabelas 4 e 5 estão os resultados da análise de solo das amostras e os valores mínimos, máximos, desvio padrão, e coeficiente de variação para os resultados obtidos nas profundiades $0 \mathrm{a}$ $20 \mathrm{~cm}$ e $20 \mathrm{a} 40 \mathrm{~cm}$, respectivamente

Os valores mínimos e máximos mostram a amplitude total dos resultados, já o desvio padrão permite avaliar a dispersão desses e o coeficiente de variação sua precisão. A grande variabilidade de tipos de solos dos pomares amostrados, as diferentes adubações e tratos culturais são refletidos nos valores observados. 


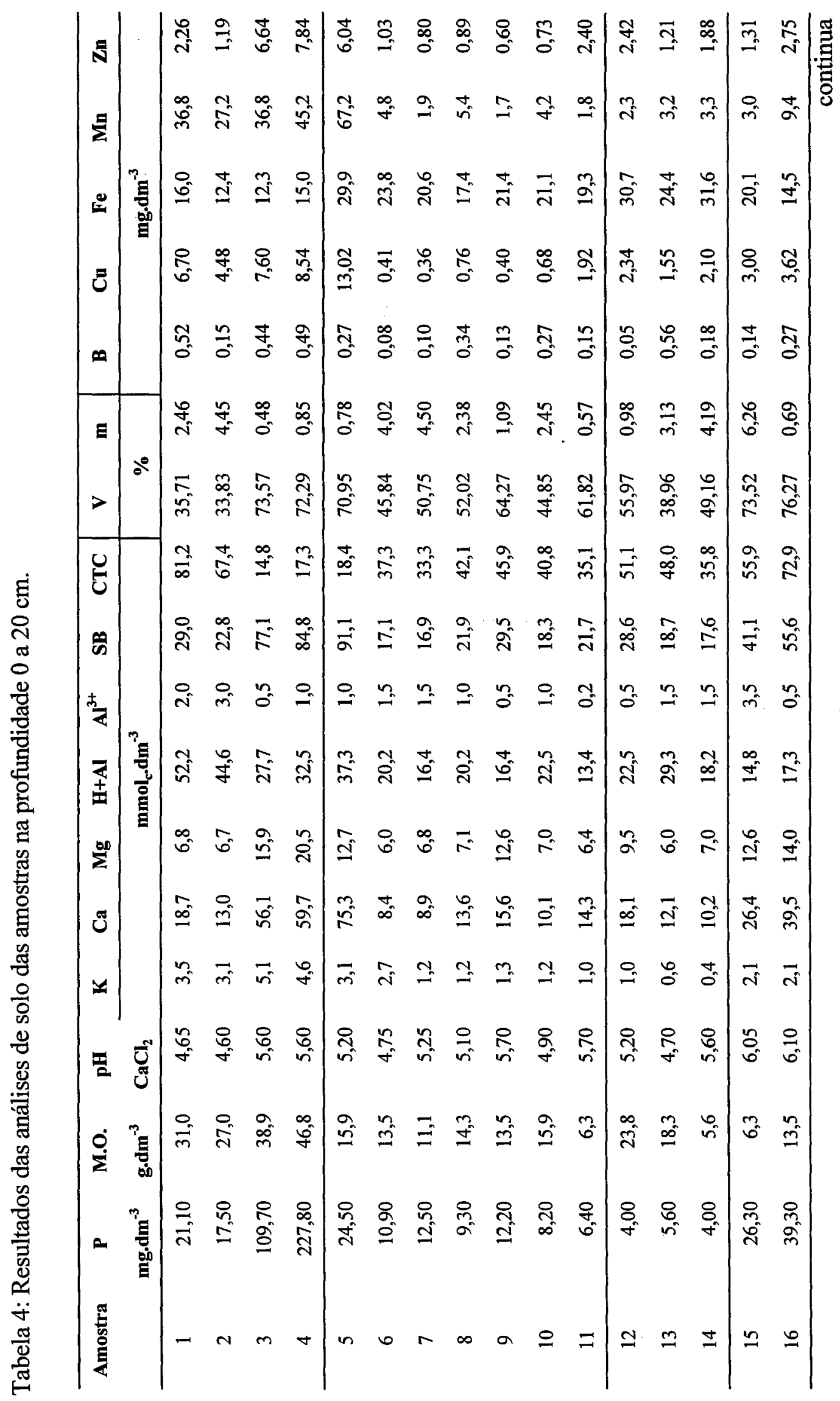




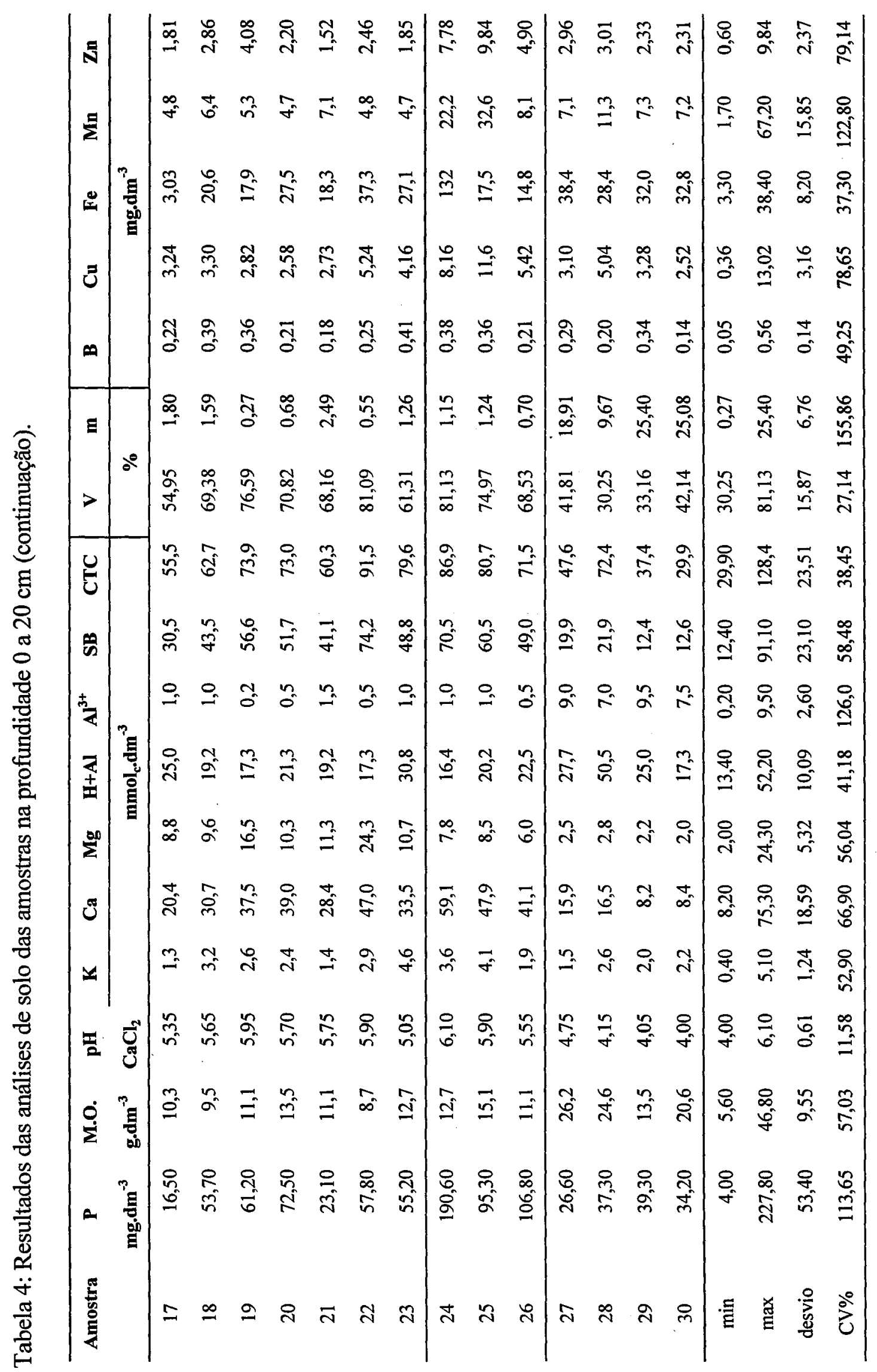




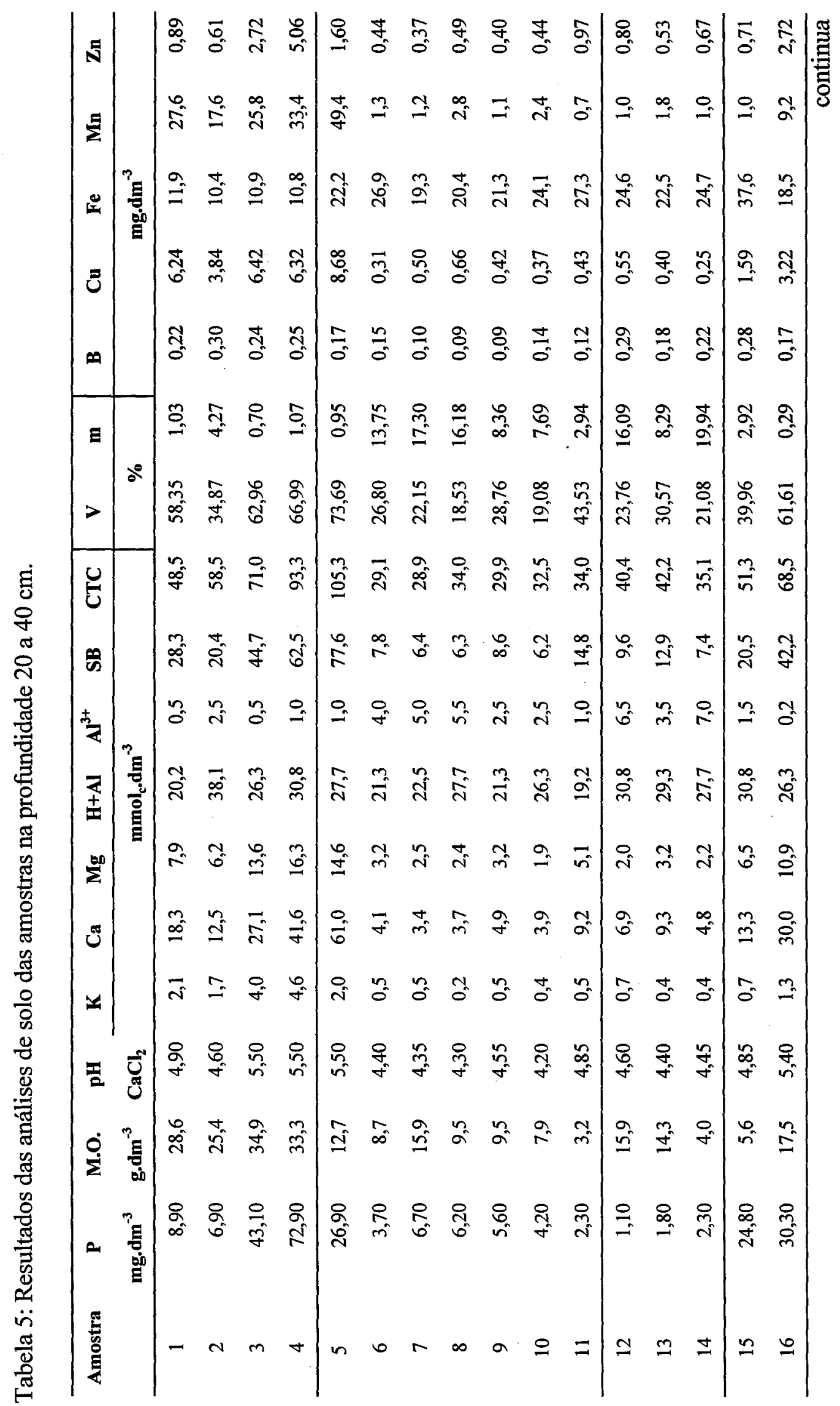




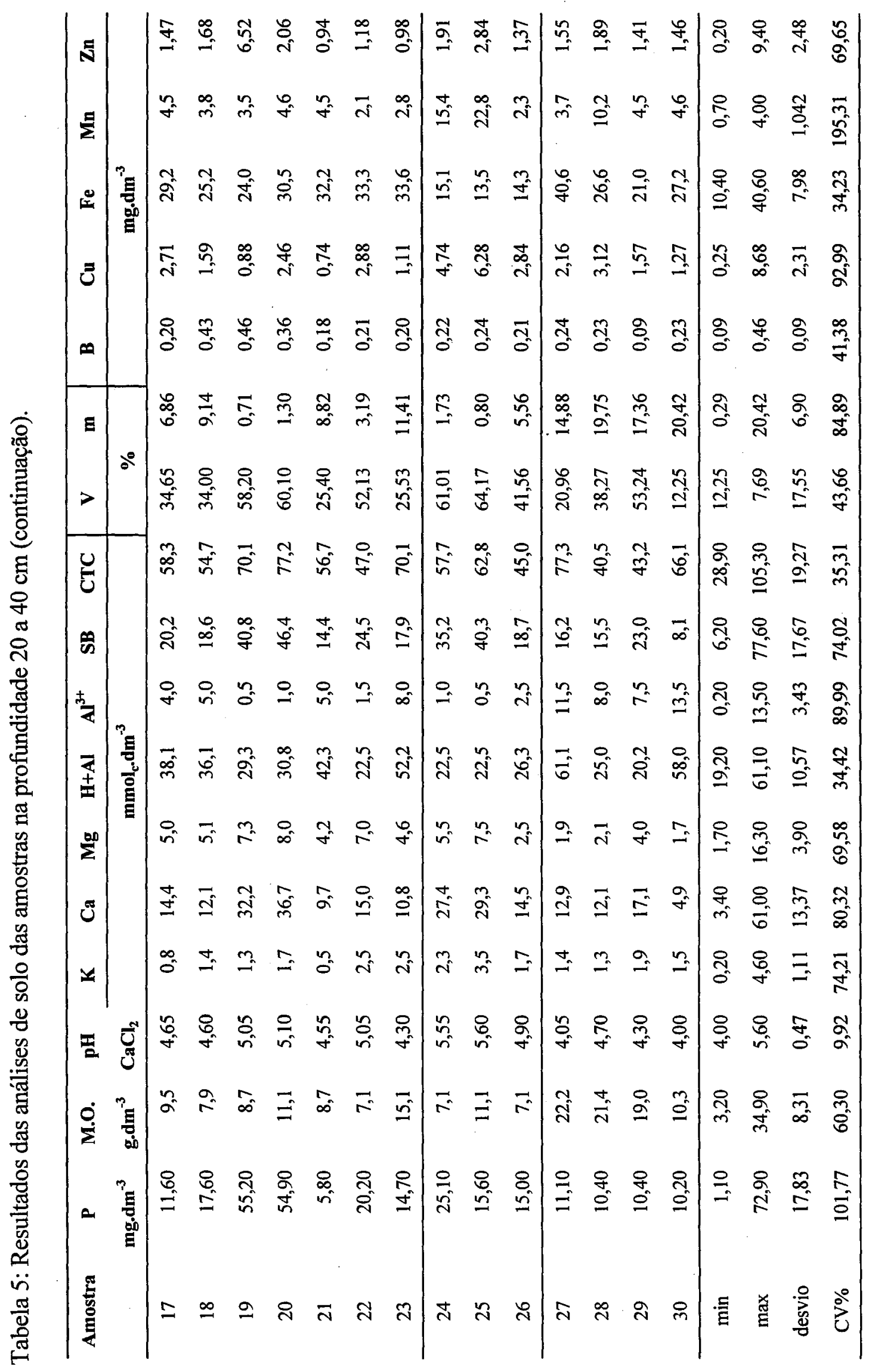




\subsubsection{Distribuição dos valores da análise de solo em faixas e classes de interpretação}

A tabela 6 apresenta a porcentagem de distribuição das amostras nas classes de teores no solo propostos pelo GRUPO PAULISTA DE ADUBAÇÃO E CALAGEM DOS CITROS (1994), para fósforo, potássio, magnésio e saturação por bases (V\%).

Tabela 6: Porcentagem de amostras observadas por classes de teores, para P, K, Mg e V\% do solo, nas duas profundidades e na média.

\begin{tabular}{cccccc}
\hline \multirow{2}{*}{$\begin{array}{c}\text { Parâmetros } \\
\text { químicos }\end{array}$} & $\begin{array}{c}\text { Profundidade } \\
(\mathbf{c m})\end{array}$ & \multicolumn{5}{c}{ Classe de teores (\% observadas) } \\
\cline { 3 - 6 } & & Muito baixo & Baixo & Médio & Alto \\
\hline $\mathrm{P}$ & $0-20$ & 13,33 & 13,33 & 33,33 & 40,00 \\
& $20-40$ & 26,67 & 30,00 & 26,67 & 16,67 \\
& média & 20,00 & 21,67 & 30,00 & 28,34 \\
\hline $\mathrm{K}$ & $0-20$ & 06,67 & 30,00 & 33,33 & 30,00 \\
& $20-40$ & 36,67 & 23,33 & 30,00 & 10,00 \\
& média & 21,67 & 26,67 & 31,67 & 20,00 \\
\hline Mg & $0-20$ & - & 13,33 & 36,67 & 50,00 \\
& $20-40$ & - & 40,00 & 46,67 & 13,33 \\
& média & - & 26,67 & 41,67 & 31,67 \\
\hline V\% & $0-20$ & 0,00 & 33,33 & 33,33 & 33,33 \\
& $20-40$ & 30,00 & 33,33 & 33,33 & 03,33 \\
& média & 15,00 & 33,33 & 33,33 & 18,33 \\
\hline
\end{tabular}

Como o cálcio domina o complexo de troca, ele somente torna-se deficiente em condições de teores muito baixos, por esse motivo não estabelecem-se as classe de teores para esse nutriente no solo. 
De acordo com os limites propostos pelo GRUPO PAULISTA DE ADUBAÇÃO E CALAGEM DOS CITROS (1994), a porcentagem das amostras na profundidade 0 a $20 \mathrm{~cm}$ com teores de fósforo considerados altos foi de $40 \%$, enquanto na camada 20 a $40 \mathrm{~cm}$ a tendência foi outra, e $30 \%$ de amostras possuiam teores de fósforo considerados baixos. Mostrando que a prática da adubação com fósforo tem atuado na correção dos teores desse nutriente na camada 0 a $20 \mathrm{~cm}$.

O potássio, na primeira camada amostrada, apresentou 33,33\% das amostras com teor médio, e $30 \%$ classificadas como alto e baixo respectivamente. Na segunda camada houve uma grande porcentagem $(36,67 \%)$ de amostras que estavam na classe de teores muito baixa. Esses teores podem estar porvocando efeitos prejudiciais, pois, como mostraram WEIR et al. (1978), o potássio tem um efeito linear sobre a produção de frutos. DU PLESSIS \& KOEN (1984) associaram solos com pouco potássio disponível a plantas deficientes nesse nutriente, cujos frutos apresentavam tamanho reduzido.

Os teores de magnésio nos solos dos pomares amostrados foram considerados altos em 50\% das amostras na camada superior, e médios em $46,67 \%$ das amostras da camada inferior. Provavelmente, o uso prolongado de cálcario dolomítico tenha aumentado esses teores.

A saturação por bases na camada de 0 a $20 \mathrm{~cm}$ dos pomares teve $33,33 \%$ das amostras distribuídas igualmente pelas classes baixa, média e alta. Na camada inferior, como era de se esperar, houve uma redução geralmente desses valores, ocorrendo $30 \%$ dos pomares na faixa muito baixa. QUAGGIO et al. (1992b) observaram que a produtividade máxima foi obtida com a saturação por bases próxima de $60 \%$. Os autores também relacionaram aumentos lineares do número de frutos, com as doses de cálcario aplicadas.

De um modo geral, os teores de fósforo e magnésio nas duas camadas estão adequados, ou próximos dos valores adequados. O potássio apresenta no geral, teores de médios a baixos, necessitando correção. A saturação por bases teve uma ditribuição mais ampla, pois haviam pomares com valores altos até pomares com teores baixos.

A tabela 7 apresenta a porcentagem das amostras, nas classes de teores no solo, para os micronutrientes boro, cobre, manganês e zinco, proposta pelo GRUPO PAULISTA DE 
ADUBAÇÃO E CALAGEM DOS CITROS (1994). O boro foi extraído com água quente e o cobre, o manganês e o zinco foram extraídos com DTPA a pH 7,3.

Os teores de boro na camada 0 a $20 \mathrm{~cm}$, foram considerados médios pelo GRUPO PAULISTA DE ADUBAÇÃO E CALAGEM DOS CITROS (1994) em 66,67\% das amostras, já na camada 20 a $40 \mathrm{~cm}$, praticamente apresentou a mesma porcentagem, 63,33\%, considerada média, mostrando que houve uma distribuição desse nutriente pelas duas camadas amostradas. Isso provavelmente foi devido à forma não dissociada $\left(\mathrm{H}_{3} \mathrm{BO}_{3}\right)$, que está normalmente presente nos solos, fazendo com que o nutriente movimente-se livremente pelo perfil.

Os teores de cobre no solo foram considerados altos em $83,33 \%$ das amostras. Na camada inferior, há uma pequena redução, porém $63,33 \%$ das amostras são consideradas altas pelo GRUPO PAULISTA DE ADUBAÇÃO E CALAGEM DOS CITROS (1994). ALVA \& CHEN (1995) observaram que um aumento na concentração externa de cobre levou a uma redução significativa do peso de material seco de raízes e da parte aérea de seedlings de dois porta-enxertos avaliados. Houve também uma redução na absorção de ferro e em menor intensidade nas absorções de manganês e zinco.

Os teores de manganês na camada 0 a $20 \mathrm{~cm}$ foram considerados altos pelo GRUPO PAULISTA DE ADUBAÇÃO E CALAGEM DOS CITROS (1994) em 60\% das amostras. Porém na camada inferior houve uma redução dos teores desse nutriente, onde houve $46,67 \%$ de amostras com teor médio.

A distribuição dos teores de zinco também foi considerada alta pelo GRUPO PAULISTA DE ADUBAÇÃO E CALAGEM DOS CITROS (1994) em 70\% dos pomares amostrados nas camadas 0 a $20 \mathrm{~cm}$, já a camada inferior existe uma distribuição idêntica da amostras (36,67\%) nas classes média e alta de teores no solo. 
Tabela 7: Porcentagem de amostras observadas por classes de teores de micronutrientes no sol, nas duas profundidades e na média.

\begin{tabular}{ccccc}
\hline $\begin{array}{c}\text { Micronutrientes } \\
\text { no solo (ppm) }\end{array}$ & $\begin{array}{c}\text { Profundidade } \\
(\mathbf{c m})\end{array}$ & \multicolumn{3}{c}{ Classes de teores (\% observadas) } \\
\cline { 3 - 5 } & & Baixo & Médio & Alto \\
\hline B & $0-20$ & 33,33 & 66,67 & 0.00 \\
& $20-40$ & 36,67 & 63,33 & 0.00 \\
& média & 35,00 & 65,00 & 0.00 \\
\hline $\mathrm{Cu}$ & $0-20$ & 0.00 & 16,67 & 83,33 \\
& $20-40$ & 0.00 & 36,67 & 63,33 \\
& média & 0.00 & 26,67 & 73,33 \\
\hline $\mathrm{Mn}$ & $0-20$ & 0.00 & 40,00 & 60,00 \\
& $20-40$ & 23,33 & 46,67 & 30,00 \\
& média & 11,67 & 43,33 & 45,00 \\
\hline $\mathrm{Zn}$ & $0-20$ & 03,33 & 26,67 & 70,00 \\
& $20-40$ & 26,67 & 36,67 & 36,67 \\
& média & 15,00 & 31,67 & 53,33 \\
\hline
\end{tabular}

É importante observar que os micronutrientes, como pode ser observado na tabela 3, foram aplicados apenas em pulverizações foliares. Entretanto, observa-se que alguns solos possuem teores altos desses nutrientes. Provavelmente, parte desses nutrientes aplicados nas folhas ter sido absorvida diretamente, enquanto outra parte, talvez bem maior, seja levada para o solo, acumulando-se com o tempo.

O nutriente boro foi o que estava em teores mais equilibrados no solo. Os teores de cobre e zinco em ambas profundidades, e o de manganês na camada superficial, demonstraram que deve estar havendo tendência de excessos. 


\subsubsection{Análise granulométrica e classificação dos solos}

$\mathrm{Na}$ tabela 8 são apresentados os resultados das análises granulométricas, texturas, classes de solo e a porcentagem de amostras observada em cada classe. Dos 30 pomares amostrados, 13,33\% estavam implantados em uma Terra Roxa Estruturada, e a maior parte das amostras em Latossolos, com variações nas texturas.

Tabela 8: Teores médios das frações texturais, classe textural, classe de solo, ans duas profundidades amostradas e a porcentagem das amostras em função da análise granulométrica e classes texturais.

\begin{tabular}{|c|c|c|c|c|c|c|}
\hline \multicolumn{3}{|c|}{ Teores no solo (g.kg $\left.{ }^{-1}\right)$} & \multirow{2}{*}{$\begin{array}{c}\text { Profundidade } \\
\text { (cm) }\end{array}$} & \multirow[t]{2}{*}{ Textura } & \multirow{2}{*}{$\begin{array}{c}\text { Classe de } \\
\text { solo }\end{array}$} & \multirow{2}{*}{$\begin{array}{c}\text { Amostras } \\
\text { (\%) }\end{array}$} \\
\hline argila & silte & areia & & & & \\
\hline 80,0 & 60,0 & 860,0 & $0-20$ & arenosa & Latossolo Vermelho-Amarelo, distrófico, & 33,33 \\
\hline 100,0 & 60,0 & 840,0 & $21-40$ & arenosa & textura média-arenosa $\left(\mathrm{LV}_{\mathrm{m} \text { ar }}\right)$ & \\
\hline 300,0 & 40,0 & 660,0 & $0-20$ & média & Latossolo Vermelho-Escuro, distrófico, textura & 30,00 \\
\hline 320,0 & 40,0 & 640,0 & $21-40$ & média & média-argilosa (LE) & \\
\hline 220,0 & 60,0 & 720,0 & $0-20$ & média & Latossolo Vermelho-Amarelo, distrófico, & 13,33 \\
\hline 280,0 & 40,0 & 680,0 & $21-40$ & média & textura média $\left(\mathrm{LV}_{\mathrm{m} 1}\right)$ & \\
\hline 200,0 & 60,0 & 740,0 & $0-20$ & média & Latossolo Vermelho-Amarelo, distrófico, & 10,00 \\
\hline 220,0 & 60,0 & 72,0 & $21-40$ & média & textura média $\left(\mathrm{LV}_{\mathrm{m} 2}\right)$ & \\
\hline 610,0 & 120,0 & 270,0 & $0-20$ & argilosa & Terra Roxa Estruturada, eutrófica, textura & 13,33 \\
\hline 590,0 & 100,0 & 310,0 & $21-40$ & argilosa & argilosa (TE) & \\
\hline
\end{tabular}

Solos com textura argilosa, como os dos pomares implantandos na TE, são comuns na região citrícola brasileira (OLIVEIRA, 1991). Esses solos presentam uma capacidade de retenção de cátions, em geral, maior que as dos solos arenosos, porém esse fator é determinado pela natureza dos componentes da fração argila. Solos com argila caulinítica, como provavelmente deve ser a TE 
em estudo, apresentam uma capacidade de retenção de cátions intermediária entre aquela dos solos argilosos oxídicos e daqueles com argila de alta atividade. De acordo com OLIVEIRA et al. (1992), esse solo pode ser considerado "eutrófico", pois apresenta saturação por bases maior que $50 \%$ ao longo do perfil amostrado. DU PLESSIS \& KOEN (1984) detectaram problemas nos teores foliares de potássio em citros cultivados em solos argiloso com alta relação $\mathrm{Ca}+\mathrm{Mg} / \mathrm{K}$.

Dos pomares amostrados, 33,33\% estavam situados um LV médio-arenoso, 30\% em um LE médio-argiloso, e $23,33 \%$ em dois LV textura média. Os solos com textura média são muito comuns nas regiões citrícolas (OLIVEIRA, 1991). RODRIGUEZ et al. (1977) já haviam relatado que a maior parte dos solos cultivados com citros em São Paulo possuem a textura superficial de arenosa a areno-argilosa. PLATT (1973), confirmando essas observações, recomendou os solos de textura média e horizontalmente homogêneos para o cultivo dos citros. HARDING \& CHAPMAN (1950), atribuíram o maior número de pomares plantados em solos de textura intermediária, ao fato de neles ser mais fácil obter-se boas produções, que naqueles com textura muito arenosa ou muito argilosa. Uma explicação para esses fatos talvez seja a fornecida por OLIVEIRA (1991), que citando outros autores, afirmou que os solos de textura média têm maior capacidade de armazenamento de água, seguidos pelos argilosos e depois pelos arenosos. Isso tem uma importância muito grande para uma cultura perene cultivada num clima como o da região em estudo, onde no período de inverno há uma pequena precipitação pluviométrica (tabela 1).

\subsection{Análise de folha}

Na tabela 9 estão os resultados da análise de folhas das amostras e os valores mínimos, máximos, desvio padrão, e coeficiente de variação.

O teor de nitrogênio nas folhas amostradas variou entre 15,50 a 29,30 g. $\mathrm{kg}^{-1}$ com um desvio padrão de 3,003. Pode ser que esteja havendo limitação da produção em alguns pomares, porque como foi demonstrado por GALLO et al. (1966) e DU PLESSIS \& KOEN (1984), o teor de nitrogênio na folha está diretamente relacionado com aumentos na produção. Para CANTARELLA 
et al. (1992), em estudos de adubação dos citros, o nitrogênio foi o nutriente que tornou maiores e mais freqüentes, as respostas em termos produção.

O teor de fósforo nas amostras variou entre 0,9 e $1,60 \mathrm{~g} \cdot \mathrm{kg}^{-1}$ e com um desvio padrão de 0,179 . O teor de potássio nas amostras foliares variou entre 4,90 e $14,50 \mathrm{~g} \cdot \mathrm{kg}^{-1}$ e com um desvio padrão de 2,652 .

Os teores de cálcio variaram de 20,50 a 40,30 g.kg ${ }^{-1}$ com um desvio padrão de 5,837. A ocorrência de teores de cálcio maiores que os de nitrogênio é pouco comum nas culturas em geral, no entanto, autores como GALLO et al. (1960) e SMTTH (1966) já haviam demonstrado essa característica calcífila das plantas cítricas. Os teores médios de potássio estão adequados e os de cálcio abaixo do nível adequado, podendo haver alguma interferência entre eles. REUTHER \& SMITH (1954) já haviam apresentado o antagonismo entre esses nutrientes. SMITH (1966), NAGAI et al. (1975) e EMBLETON et al. (1978) mostraram que os aumentos nos teores foliares de potássio levaram à redução nos teores de cálcio. WEIR (1969) observou que o potássio era o nutriente mais fortemente antagônico das bases estudadas, mas esse antagonismo foi mais forte entre o potássio e o cálcio, que entre o potássio e o magnésio.

A variação do teor de magnésio nas fohas foi de 1,30 a $5,30 \mathrm{~g} \cdot \mathrm{kg}^{-1}$ e com desvio padrão de 1,208. REUTHER \& SMITH (1954) haviam relatado que o excesso de potássio poderia prejudicar a absorção de magnésio, o que mais tarde foi confirmado por RODRIGUEZ et al. (1973). Segundo QUAGGIO et al. (1992a), os sintomas visuais de deficiência de magnésio são muito freqüentes nos pomares paulistas.

RODRIGUEZZ \& GALLO (1961) alertaram que, no caso dos cátions, deve-se observar um equilíbrio no fornecimento de potássio, cálcio e magnésio, para evitar-se o desequilíbrio.

A análises das amostras de folha revelaram teores de enxofre entre 1,00 e $3,40 \mathrm{~g}^{-\mathrm{kg}^{-1}}$, com um desvio padrão de 0,048. MALAVOLTA \& VIOLANTE NETTO (1988) forneceram enxofre para os citros e observaram aumentos de $16 \%$ na produção, quando o teor foliar foi de $0,275 \%$. 
Tabela 9: Resultados das análises de folhas das amostras.

\begin{tabular}{|c|c|c|c|c|c|c|c|c|c|c|c|}
\hline \multirow[t]{2}{*}{ Amostra } & $\mathbf{N}$ & $\mathbf{P}$ & $\mathbf{K}$ & $\mathrm{Ca}$ & Mg & $\mathbf{S}$ & B & $\mathrm{Cu}$ & $\mathbf{F e}$ & Mn & $\mathbf{Z n}$ \\
\hline & \multicolumn{6}{|c|}{ g.kg ${ }^{-1}$} & \multicolumn{5}{|c|}{ mg.kg-1 } \\
\hline 1 & 22,1 & 1,1 & 13,0 & 36,3 & 1,6 & 1,6 & 68 & 55 & 245 & 27 & 89 \\
\hline 2 & 25,5 & 0,9 & 13,8 & 24,1 & 2,5 & 1,8 & 57 & 36 & 258 & 25 & 74 \\
\hline 3 & 26,3 & 1,1 & 12,2 & 40,3 & 2,1 & 2,0 & 69 & 41 & 351 & 10 & 100 \\
\hline 4 & 23,8 & 0,9 & 9,2 & 22,9 & 2,5 & 2,5 & 65 & 54 & 237 & 38 & 93 \\
\hline 5 & 23,9 & 1,2 & 14,5 & 20,5 & 1,6 & 1,6 & 42 & 37 & 186 & 37 & 22 \\
\hline 6 & 24,1 & 1,6 & 11,5 & 28,5 & 4,8 & $1,9$. & 123 & 42 & 229 & 10 & 123 \\
\hline 7 & 29,3 & 1,4 & 11,5 & 35,8 & 4,8 & 2,1 & 111 & 45 & 123 & 4 & 35 \\
\hline 8 & 22,7 & 1,4 & 9,2 & 38,7 & 5,3 & 1,9 & 64 & 27 & 204 & 15 & 35 \\
\hline 9 & 26,7 & 1,5 & 12,2 & 31,7 & 5,3 & 2,0 & 54 & 32 & 112 & 5 & 48 \\
\hline 10 & 23,4 & 1,3 & 10,7 & 33,1 & 5,2 & 1,4 & 64 & 34 & 140 & 14 & 45 \\
\hline 11 & 20,9 & 1,1 & 13,0 & 22,5 & 2,4 & 2,6 & 82 & 32 & 167 & 4 & 49 \\
\hline 12 & 25,3 & 1,0 & 9,2 & 29,3 & 2,5 & 2,0 & 109 & 48 & 143 & 3 & 83 \\
\hline 13 & 19,6 & 0,9 & 5,4 & 28,3 & 2,7 & 1,9 & 136 & 41 & 198 & 2 & 87 \\
\hline 14 & 19,7 & 1,0 & 6,1 & 27,3 & 2,3 & 2,1 & 109 & 39 & 228 & 10 & 83 \\
\hline 15 & 26,6 & 1,0 & 9,9 & 22,9 & 2,8 & 2,5 & 63 & 41 & 118 & 21 & 20 \\
\hline 16 & 23,1 & 1,2 & 13,8 & 31,8 & 4,0 & 1,4 & 46 & 29 & 210 & 35 & 73 \\
\hline 17 & 23,0 & 1,1 & 10,7 & 26,6 & 3,9 & 1,8 & 44 & 46 & 172 & 29 & 63 \\
\hline 18 & 19,7 & 1,0 & 13,8 & 21,7 & 3,0 & 2,1 & 78 & 29 & 168 & 38 & 50 \\
\hline 19 & 20,2 & 1,1 & 13,8 & 30,9 & 3,0 & 1,0 & 83 & 19 & 205 & 30 & 50 \\
\hline 20 & 18,1 & 1,2 & 12,2 & 21,7 & 2,0 & 3,4 & 53 & 31 & 143 & 6 & 57 \\
\hline 21 & 21,8 & 1,1 & 4,9 & 31,4 & 2,9 & 1,9 & 57 & 31 & 136 & 38 & 43 \\
\hline 22 & 19,0 & 1,1 & 10,7 & 33,0 & 3,4 & 2,7 & 35 & 40 & 214 & 38 & 36 \\
\hline 23 & 24,1 & 1,1 & 9,2 & 28,0 & 2,9 & 1,3 & 54 & 47 & 204 & 22 & 61 \\
\hline 24 & 21,0 & 1,0 & 6,1 & 38,3 & 1,3 & 2,5 & 47 & 54 & 292 & 35 & 43 \\
\hline 25 & 15,5 & 0,9 & 8,4 & 40,1 & 1,7 & 2,2 & 42 & 62 & 311 & 72 & 45 \\
\hline 26 & 19,3 & 1,1 & 10,7 & 35,1 & 2,3 & 1,6 & 46 & 60 & 215 & 9 & 39 \\
\hline
\end{tabular}


Tabela 9: Resultados das análises de folhas das amostras (continuação).

\begin{tabular}{|c|c|c|c|c|c|c|c|c|c|c|c|}
\hline \multirow[t]{2}{*}{ Amostra } & $\mathbf{N}$ & $\mathbf{P}$ & $\mathbf{K}$ & $\mathrm{Ca}$ & Mg & $\mathbf{S}$ & B & $\mathbf{C u}$ & $\mathbf{F e}$ & Mn & $\mathbf{Z n}$ \\
\hline & \multicolumn{6}{|c|}{ g. $\mathrm{kg}^{-1}$} & \multicolumn{5}{|c|}{ mg.kg ${ }^{-1}$} \\
\hline 27 & 23,4 & 1,0 & 8,4 & 24,4 & 1,3 & 2,2 & 47 & 58 & 212 & 16 & 86 \\
\hline 28 & 24,8 & 1,1 & 11,5 & 29,2 & 1,9 & 2,2 & 45 & 61 & 283 & 9 & 55 \\
\hline 29 & 24,5 & 0,9 & 13,0 & 26,8 & 1,8 & 1,8 & 46 & 76 & 221 & 15 & 113 \\
\hline 30 & 24,8 & 1,0 & 12,2 & 34,3 & 2,0 & 1,5 & 56 & 61 & 242 & 13 & 110 \\
\hline $\min$ & 15,5 & 0,9 & 4,9 & 20,5 & 1,3 & 1,0 & 35 & 19 & 112 & 2 & 22 \\
\hline $\max$ & 29,3 & 1,6 & 14,5 & 40,3 & 5,3 & 3,4 & 136 & 76 & 351 & 72 & 123 \\
\hline desvio & 3,00 & 0,18 & 2,65 & 5,84 & 1,21 & 0,05 & 26,43 & 13,13 & 58,29 & 15,77 & 27,59 \\
\hline CV\% & 13,21 & 16,11 & 24,80 & 19,55 & 42,26 & 24,42 & 39,75 & 30,11 & 28,36 & 75,07 & 43,34 \\
\hline
\end{tabular}

As deficiências de alguns micronutrientes como cobre, ferro, manganês e zinco, estão associadas em muitos casos, com o alto nível de nitrogênio e potássio e baixo de cálcio nas folhas, segundo REUTHER \& SMITH (1954). Porém, os resumos das relações entre os nutrientes apresentados por SMITH (1966) e por EMBLETON et al. (1978) não confirmam essas relações. Outro macronutriente que influencia os micronutrientes é o magnésio. Segundo SMITH (1966), esse nutriente favorece o acúmulo de zinco e de manganês nas folhas, deslocando-os das raízes para a parte aérea, porém com o cobre ocorre o inverso.

As análises foliares revelaram que os teores de boro nas folhas amostradas variaram entre 35 e $136 \mathrm{mg} \cdot \mathrm{kg}^{-1}$, com um desvio padrão de 26,434. Os teores de cobre variaram entre 19 e 76 $\mathrm{mg} . \mathrm{kg}^{-1}$ e com desvio padrão de 13,130. O excesso de cobre pode levar a desbalanços nutricionais, como foi demonstrado por ALVA \& CHEN (1995), provocando redução nos teores foliares principalmente de ferro e com menor intensidade nos teores de zinco e de manganês.

O micronutriente ferro nas amostras, variou de 112 a $351 \mathrm{mg} \cdot \mathrm{kg}^{-1}$, com um desvio de 58,293 . Os teores de manganês nas amostras dos 30 pomares variaram de 2 a $72 \mathrm{mg} . \mathrm{kg}^{-1}$, com um desvio padrão de 15,760. Esses resultados estão bastante próximos daqueles obtidos por 
RODRIGUEZ \& GALLO (1961), para esse micronutriente. A amplitude de variação do zinco nas análises foliares foi de 2 a $163 \mathrm{mg} \cdot \mathrm{kg}^{-1}$, com um desvio padrão de 27,594.

\subsubsection{Distribuição dos valores da análise foliar em faixas e classes de interpretação}

Na tabela 10 são apresentadas as freqüências de distribuição das amostras dentro das faixas de interpretação propostas pelo GRUPO PAULISTA DE ADUBAÇÃO E CALAGEM DOS CITROS (1994), para os teores foliares de nitrogênio, fósforo, potássio, cálcio, magnésio, enxofre, boro, cobre, ferro, manganês e zinco.

Com relação aos macronutrientes, o cálcio e o fósforo são os que apresentaram maiores porcentagem de deficiência $(76,67$ e $73,33 \%$ do total amostrado, respectivamente). $O$ mesmo já havia sido observado para o fósforo por RODRIGUEZ \& GALLO (1961) e CAETANO et al. (1984) com a laranjeira 'Valência' e por HIROCE (1984), no segundo ano de um levantamento de três anos.

O macronutriente enxofre apresentou tełores considerados deficientes em $50 \%$ dos pomares. Confirmando indiretamente as observações de MALAVOLTA \& VIOLANTE NETTO (1988), que relataram efeitos positivos das aplicações de fontes de enxofre na cultura dos citros.

Nitrogênio e magnésio estão deficientes em 43,33\% dos pomares amostrados, enquanto que o potássio está deficiente em $40 \%$ dos poamres. O nitrogênio e o potássio contudo, são os macronutrientes que apresentam as maiores porcentagens de pomares na faixa adequada (56,67 e $60 \%$, respectivamente), indicando que as adubações desses nutrientes têm sido feita de modo ideal. CAETANO et al. (1984) praticamente não observaram teores deficientes de nitrogênio nos pomares amostrados. CAETANO et al. (1984), em laranjeiras 'Valência', e HIROCE (1984), trabalhando com as amostras enviadas para análise no IAC, relataram que $30 \%$ dessas estavam deficientes em potássio. No então, uma alta incidência de deficiência de magnésio foi observada por RODRIGUEZ \& GALLO (1961), CAETANO et al. (1984) e HIROCE (1984). QUAGGIO et al. (1992a) confirmaram que a deficiência de magnésio é muito freqüente nos pomares de citros do Estado de São Paulo. 
Tabela 10: Porcentagens de amostras nas faixas de interpretação, para os teores de $\mathrm{N}, \mathrm{P}, \mathrm{K}, \mathrm{Ca}, \mathrm{Mg}$, $\mathrm{S}, \mathrm{B}, \mathrm{Cu}, \mathrm{Fe}, \mathrm{Mn}$ e $\mathrm{Zn}$ nas folhas de laranjeira 'Valência'.

\begin{tabular}{cccc}
\hline \multirow{2}{*}{$\begin{array}{c}\text { Nutrientes } \\
\text { na folha }\end{array}$} & \multicolumn{3}{c}{ Faixas de interpretação (\% observada) } \\
\cline { 2 - 4 } & baixo & adequado & excessivo \\
\hline $\mathrm{N}$ & 43,33 & 56,67 & - \\
$\mathrm{P}$ & 73,33 & 26,67 & - \\
$\mathrm{K}$ & 40,00 & 60,00 & - \\
$\mathrm{Ca}$ & 76,67 & 23,33 & 10,00 \\
$\mathrm{Mg}$ & 43,33 & 46,67 & - \\
$\mathrm{S}$ & 50,00 & 50,00 & - \\
$\mathrm{B}$ & 3,33 & 96,67 & 100,00 \\
$\mathrm{Cu}$ & - & - & 60,00 \\
$\mathrm{Fe}$ & - & 40,00 & - \\
$\mathrm{Mn}$ & 73,33 & 26,67 & 10,00 \\
$\mathrm{Zn}$ & 6,67 & 83,33 &
\end{tabular}

Com relação aos micronutrientes, boro e zinco estão adequados, indicando que as pulverizações foliares desses nutrientes têm sido eficientes na manutenção dos níveis adequados pode-se, de certa forma afirmar, que está havendo uma melhoria no fornecimento desses micronutriente, pois nos levantamentos relatados por RODRIGUEZ \& GALLO (1961), CAETANO et al. (1984) e HIROCE (1984), as deficiências de boro e zinco estavam presentes em aproximadamente $50 \%$ das amostras.

Os elevados teores de cobre, considerados excessivos na totalidade, podem ser resultados da aplicação do elemento por via foliar, como fungicida. CAETANO et al. (1984) já haviam observado essa mesma situação. HIROCE (1984), no entanto, observou a ocorrência de deficiência 
de cobre em $61 \%$ das amostras coletadas, no último ano do levantamento realizado entre 1963 e 1965.

O micronutriente com maior porcentagem de ocorrência de deficiência foi o manganês, com $73,33 \%$ das amostras. Nos levantamentos consultados, não haviam sido relatadas deficiências dessa extensão, para esse nutriente.

Os teores foliares de ferro dos pomares em estudo são considerados adequados em $40 \%$ e excessivos em $60 \%$. A explicação pode estar nos limites da classes, que podem estar inadequados para a realidade dos pomares amostrados.

\subsection{Regressão linear múltipla}

\subsubsection{Parâmetros do solo}

Em cada subítem são apresentadas as equações obtidas através do método do $\mathrm{R}^{2}$ máximo, utilizando as 30 observações e as 48 variáveis referente às duas profundidades do solo e seus coeficientes de determinação. A escolha das equações foi sempre aquela que apresentasse maior $\mathrm{R}^{2}$, menor Quadrado Médio do Resíduo, porém com os Graus de Liberdade do Resíduo maiores que 10.

\subsubsection{Produção Relativa (PR)}

A equação obtida para a Produção Relativa possui 17 variáveis, sendo que dessas, 6 são referentes à profundidade 0 a $20 \mathrm{~cm}$ e 11 à profundidade 20 a $40 \mathrm{~cm}$, e explica 98,3\% das variações observadas. A tabela 11 do apêndice apresenta o quadro da análise de variância e os coeficientes de determinação e o coeficiente ajustado e na tabela 12 do apêndice aparece a equação escolhida e o teste $\mathrm{F}$ de cada variável (as letras A e B que seguem cada variável indicam as profundidades 0 a 20 e 20 a $40 \mathrm{~cm}$, respectivamente). 
$\mathrm{PR}(\%)=-10,505+0,362 \mathrm{P}_{\mathrm{A}}-1,126 \mathrm{P}_{\mathrm{B}}+2,625 \mathrm{M} \cdot \mathrm{O}_{\mathrm{B}}+6,707 \mathrm{~K}_{\mathrm{A}}-37,621 \mathrm{~K}_{\mathrm{B}}-0,884 \mathrm{Ca}_{\mathrm{A}}-$ $1,396 \mathrm{H}+\mathrm{Al}_{\mathrm{A}}-11,283 \mathrm{Al}^{3+}{ }_{\mathrm{B}}+0,968 \mathrm{CTC}_{\mathrm{B}}+4,798 \mathrm{~m}_{\mathrm{B}}+118,532 \mathrm{~B}_{\mathrm{B}}+18,884 \mathrm{Cu}_{\mathrm{B}}+1,411$ $\mathrm{Fe}_{\mathrm{B}}+1,278 \mathrm{Mn}_{\mathrm{A}}-2,752 \mathrm{Mn}_{\mathrm{B}}+5,063 \mathrm{Zn}_{\mathrm{B}}+0,614 \mathrm{Mg} / \mathrm{K}_{\mathrm{A}}$

A matéria-orgânica, da camada 20 a $40 \mathrm{~cm}$, teve um efeito positivo sobre a produção. $O$ papel da matéria-orgânica do solo pode ser como fonte de nutrientes, na estrutura e agregação ou ainda na origem da capacidade de troca de cátions. DASBERG (1987) já havia relatado que a matéria orgânica é uma fonte importante de nitrogênio para as plantas cítricas, além das próprias reservas internas da planta, principalmente quando as adubações com esse nutriente são reduzidas.

Como pode ser observado na equação, o potássio na camada mais superficial, 0 a $20 \mathrm{~cm}$, teve um efeito positivo sobre a produção, concordando com as afirmações de REESE \& KOO (1975).

$O$ fósforo na camada 0 a $20 \mathrm{~cm}$ teve um efeito positivo sobre a PR. No entanto o teor de fósforo na camada mais profunda, 20 a $40 \mathrm{~cm}$, está afetando negativamente a produção, provavelmente devido aos valores excessivos desse nutriente, que pode também ser comprovado pelo fato do zinco na mesma profundidade estar afetando positivamente a produção. $O$ fósforo e o zinco têm uma relação antagônica, segundo EMBLETON et al. (1975), e o aumento na absorção do primeiro ocasionará a redução nos teores do outro.

Os solos das regiões que estavam anteriormente sob cerrado são naturalmente pobres em micronutrientes, fator que se não for corrigido, pode limitar a produção. A equação obtida comprova essa afirmação, pois indica que os pomares estudados respondem positivamente ao aumento dos teores de manganês na camada superficial e de boro, cobre, ferro e zinco na profundidade 20 a $40 \mathrm{~cm}$. No entanto o manganês em profundidade está limitando a produção, provavelmente porque com o aumento da profundidade há uma redução do $\mathrm{pH}$, que contribui para o aumento da disponibilidade desse elemento, elevando dessa maneira seus teores a níveis que podem provocar toxidez (MALAVOLTA et al., 1989 e RAIJ, 1991).

O macronutriente cálcio está em desbalanço na superfície, pois pela equação, está afetando negativamente a produção. Provavelmente o cálcio esteja em excesso nessa camada o que pode ser comprovado pelo potássio, que na superfície está em teores baixos e na subsuperfície em teores 
mais elevados. Como o cálcio é preferencialmente adsorvido, de acordo com a série liotrópica (RAIJ, 1991), o potássio pode estar sendo deslocado para a camada inferior, conforme já relatou QUAGGIO et al. (1992b).

A equação mostra também, o efeito negativo do $\mathrm{H}+\mathrm{AL}$ em superficie e do $\mathrm{Al}^{3+}$ trocável em subsuperficie. MARTIN \& PAGE (1969) observaram a redução do crescimento nos citros, quando $\mathrm{pH}$ era inferior a 5,0 e era alta a atividade do $\mathrm{Al}$ trocável.

A CTC na profundidade 20 a $40 \mathrm{~cm}$ também teve um efeito positivo sobre a produção, mostrando a necessidade de práticas de manejo como a calagem. QUAGGIO et al. (1992b) observaram que a calagem produziu efeitos positivos até a profundidade de $60 \mathrm{~cm}$.

A saturação por alumínio em profundidade, está diretamente relacionada com a PR, porém os valores observados para esse parâmetro são baixos, portanto não suficientes para provocar danos ao crescimento vegetal.

A relação $\mathrm{Mg} / \mathrm{K}$ apresentou um feito positivo, confirmando os relatos de SMITH (1966) e RODRIGUEZ (1991), segundo os quais, o citros têm grande exigência em magnésio. E também as observações de RODRIGUEZ et al. (1973) de que as doses mais elevadas de potássio nos experimentos de adubação reduziram a absorção de magnésio. PRATT et al. (1957) observou que para manter um nível adequado de magnésio para a cultura, a relação $\mathrm{Mg} / \mathrm{K}$ deve ser em torno de 5 .

\subsubsection{Massa média dos frutos}

A equação obtida para a massa média dos frutos possui 18 variáveis, sendo que dessas, 6 são referentes à profundidade 0 a $20 \mathrm{~cm}$ e 12 à profundidade 20 a $40 \mathrm{~cm}$, e explica $98,4 \%$ das variações observadas. Na tabela 13 do apêndice é apresentado o quadro da análise de variância e os coeficientes de determinação e o coeficiente ajustado e na tabela 14 do apêndice é apresentado a equação escolhida e o teste $\mathrm{F}$ de cada variável (as letras $\mathrm{A}$ e B que seguem cada variável indicam as profundidades 0 a 20 e 20 a $40 \mathrm{~cm}$, respectivamente). 
Frutos $(\mathrm{g})=201,493-0,165 \mathrm{P}_{\mathrm{A}}+0,528 \mathrm{P}_{\mathrm{B}}+59,509 \mathrm{pH}_{\mathrm{A}}-45,934 \mathrm{pH}_{\mathrm{B}}+14,115 \mathrm{~K}_{\mathrm{A}}+18,044$

$\mathrm{K}_{\mathrm{B}}+0,797 \mathrm{Ca}_{\mathrm{B}}-4,901 \mathrm{Al}^{3+}{ }_{\mathrm{B}}-1,964 \mathrm{CTC}_{\mathrm{B}}+2,159 \mathrm{~m}_{\mathrm{A}}+3,232 \mathrm{~m}_{\mathrm{B}}+15,863 \mathrm{Cu}_{\mathrm{B}}-0,844$

$\mathrm{Fe}_{\mathrm{A}}+0,841 \mathrm{Fe}_{\mathrm{B}}-1,429 \mathrm{Ca} / \mathrm{K}_{\mathrm{A}}+1,594 \mathrm{Ca} / \mathrm{K}_{\mathrm{B}}-9,430 \mathrm{Mg} / \mathrm{K}_{\mathrm{B}}-36,282 \mathrm{~K}_{\mathrm{CTC} \text { }}$

$\mathrm{O}$ teor de potássio teve um efeito positivo sobre a massa média dos frutos em ambas as camadas amostradas. REITZ \& KOO (1960) também observaram que o potássio aplicado aumentou o peso dos frutos.

$\mathrm{O}$ teor de fósforo teve um efeito aparentemente conflitante, pois na camada superior ele foi negativo em relação à massa dos frutos, enquanto na camada inferior foi positivo.

A acidez ativa, representada pelo índice do $\mathrm{pH}$, na camada superficial, teve um efeito positivo sobre o peso do fruto, já na camada subsuperficial o efeito foi negativo.

A saturação em alumínio (m) em ambas profundidades tem uma relação direta com a massa média dos frutos, de acordo com a equação obtida. No entanto, isso ocorreu somente dentro dos limites em que foi testada a equação, ou seja, são solos em que a saturação por aluminio foi no geral baixa (tabelas 12 e 13 do apêndice) em ambas as profundidades. Confirmando isso temos que não foi observado o caráter álico em nenhum dos solos estudados. Já o alumínio trocável mostrou efeitos deletérios sobre a massa média dos frutos.

$\mathrm{O}$ ferro na camada 0 a $20 \mathrm{~cm}$ relacionou-se inversamente com o peso dos frutos, porém o ferro e o cobre, na camada 20 a $40 \mathrm{~cm}$, relacionaram-se positivamente.

A relação $\mathrm{Ca} / \mathrm{K}$ foi negativa na superfície e positiva em subsuperfície e novamente mostra que o cálcio provavelmente está em excesso na camada 0 a $20 \mathrm{~cm}$ e os teores mais baixos de potássio estão na camada $20 \mathrm{a} 40 \mathrm{~cm}$.

Nos citros, a importância da relação $\mathrm{Ca} / \mathrm{K}$ está associada com sua alta exigência em cálcio. WEIR (1969) realizou o balanço de cátions e ânions nas folhas em vários experimentos de calagem e adubação com citros, mostrando que o potássio é o nutriente mais antagônico em relação a outras bases. Esse antagonismo é ainda mais acentuado com o cálcio do que com o magnésio. QUAGGIO et al. (1992b) confirmaram a existência de um forte antagonismo entre o cálcio e o potássio, e concluiram que a relação $\mathrm{Ca} / \mathrm{K}$ no solo é importante para assegurar um bom suprimento de cálcio para as plantas e uma alta produtividade. 
A relação $\mathrm{Mg} / \mathrm{K}$ na camada inferior foi negativa para o peso dos frutos. Para os teores de magnésio em relação ao potássio é provável que estejam desbalanceados e excessivos.

A porcentagem da CTC ocupada pelo potássio na camada 20 a $40 \mathrm{~cm}$ relacionou-se negativamente com o peso de seus frutos. O mesmo ocorrendo com a CTC nessa profundidade. Mais uma vez, levanta-se a hipótese de estar havendo deslocamento de potássio para baixo, tornando-o excessivo nessa porção de solo. MARTIN et al. (1953) observaram que houve redução no crescimento dos citros quando o potássio era maior que $8,0 \%$ da CTC.

\subsubsection{Espessura da casca}

A equação obtida para a espessura da casca possui 17 variáveis, sendo que dessas, 11 são referentes à profundidade 0 a $20 \mathrm{~cm}$ e 6 à profundidade 20 a $40 \mathrm{~cm}$, e explica $92,5 \%$ das variações observadas. $\mathrm{Na}$ tabela 15 do apêndice é apresentado o quadro da análise de variância e os coeficientes de determinação e o coeficiente ajustado e na tabela 16 do apêndice está a equação escolhida e o teste F de cada variável (as letras A e B que seguem cada variável indicam as profundidades 0 a 20 e 20 a $40 \mathrm{~cm}$, respectivamente).

$$
\begin{gathered}
\text { Casca }(\mathrm{mm})=-24,847+0,061 \operatorname{argila}_{\mathrm{A}}+0,962 \mathrm{M} . \mathrm{O}_{\mathrm{B}}+116,220 \mathrm{pH}_{\mathrm{A}}+9,005 \mathrm{~K}_{\mathrm{A}}-30,148 \mathrm{~K}_{\mathrm{B}} \\
-1,910 \mathrm{H}+\mathrm{Al}_{\mathrm{A}}+7,700 \mathrm{Al}_{\mathrm{B}}^{3+}+2,300 \mathrm{SB}_{\mathrm{A}}-0,756 \mathrm{CTC}_{\mathrm{B}}-5,039 \mathrm{~V}_{\mathrm{A}}+77,870 \mathrm{~B}_{\mathrm{A}}-0,494 \\
\mathrm{Fe}_{\mathrm{A}}+0,655 \mathrm{Fe}_{\mathrm{B}}+5,097 \mathrm{Zn}_{\mathrm{A}}-4,458 \mathrm{Ca} / \mathrm{K}_{\mathrm{A}}+1,808 \mathrm{Ca} / \mathrm{K}_{\mathrm{B}}+1,405 \mathrm{Mg}_{\mathrm{CTC} \mathrm{A}}
\end{gathered}
$$

$O$ teor de argila na camada superficial influenciou positivamente a espessura da casca. Foi a única equação na qual esse parâmetro físico esteve presente. Essa observação concorda com BARAKIVA e HAMOU (1979), que obtiveram frutos com casca mais espessa em um solo com mais argila.

Houve um efeito positivo da matéria orgânica da camada inferior e do $\mathrm{pH}$ da camada superior sobre a espessura da casca. O potássio na camada superficial teve uma relação direta com a espessura da casca, concordando assim com as afirmações de WEIR et al. (1978) e o potássio da subsuperfície mostrou relação inversa. 
A saturação por bases da camada superior teve um efeito negativo sobre a espessura da casca, porém a soma de bases mostrou um efeito positivo sobre esse parâmetro. Aparentemente há uma incoerência nesses parâmetros, porém deve-se levar em conta que o fator que pode estar tornando o efeito da V\% negativo, é na verdade a acidez potencial que tem efeito negativo, ou seja, quanto maior o $\mathrm{H}+\mathrm{Al}$, menor será a espessura da casca.

Na camada inferior, a CTC teve efeito negativo sobre a espessura da casca devido provavelmente aos teores potássio nesta camada. $\mathrm{O} \mathrm{Al}^{3+}$ teve efeito direto sobre a espessura da casca.

Os teores de boro e de zinco na camada superfícial relacionaram-se positivamente com a espessura da casca, enquanto o ferro na mesma camada teve efeito oposto. $O$ teor de ferro na camada inferiore relacionou-se negativamente com a espessura da casca.

Comprovando que há excesso de $\mathrm{Ca}$, a relação $\mathrm{Ca} / \mathrm{K}$ na profundidade de 0 a $20 \mathrm{~cm}$ é negativa, ou seja confirma o efeito positivo de potássio, porque quanto menor for a relação mais potássio haverá no solo. Já na subsuperfície a mesma relação tem efeito inverso, ou seja positivo.

A porcentagem de magnésio na CTC tem um efeito positivo sobre a espessura da casca. Apesar de REUTHER \& SMITH (1952) não terem observado o efeito da aplicação desse nutriente em laranjeiras 'Valência'.

\subsubsection{Rendimento de suco}

A equação obtida para o rendimento de suco possui 18 variáveis, sendo que dessas, 8 são referentes à profundidade de 0 a $20 \mathrm{~cm}$ e 10 à profundidade de 20 a $40 \mathrm{~cm}$, e explica $97,7 \%$ das variações observadas. Na tabela 17 do apêndice é apresentado o quadro da análise de variância e os coeficientes de determinação e o coeficiente ajustado e na tabela 18 do apêndice está a equação escolhida e o teste $\mathrm{F}$ de cada variável (as letras A e B que seguem cada variável indicam as profundidades 0 a 20 e 20 a $40 \mathrm{~cm}$, respectivamente). 
Suco (\%) $=37,432-0,012 \mathrm{P}_{\mathrm{A}}-0,166 \mathrm{P}_{\mathrm{B}}+0,115 \mathrm{M} \cdot \mathrm{O}_{\mathrm{A}_{\mathrm{A}}}-0,415 \mathrm{M} . \mathrm{O}_{\mathrm{B}}+2,560 \mathrm{pH}_{\mathrm{B}}-2,948 \mathrm{~K}_{\mathrm{A}}+$ $0,402 \mathrm{Ca}_{\mathrm{B}}+0,926 \mathrm{Al}_{\mathrm{B}}^{3+}+0,053 \mathrm{SB}_{\mathrm{A}}+0,174 \mathrm{CTC}_{\mathrm{A}}+3,192 \mathrm{~B}_{\mathrm{B}}-0,504 \mathrm{Cu}_{\mathrm{A}}-0,204 \mathrm{Fe}_{\mathrm{B}}-$ $0,445 \mathrm{Ca} / \mathrm{K}_{\mathrm{A}}+0,692 \mathrm{Ca} / \mathrm{Mg}_{\mathrm{B}}-0,173 \mathrm{Ca}_{\text {CTC B }}+0,563 \mathrm{Mg}_{\text {CTC B }}+0,487 \mathrm{~K}_{\mathrm{CTC} \text { A }}$

Pela equação observa-se que há um efeito negativo do fósforo, em ambas as camadas sobre o rendimento de suco, discordando dos resultados de WEIR et al. (1978), que observaram aumentos lineares no rendimento de suco com os aumentos nas doses de fósforo.

A matéria-orgânica na superfície teve efeito positivo sobre o rendimento de suco, porém a matéria-orgânica na outra camada teve um efeito contrário.

O potássio na superfície influenciou negativamente a porcentagem de suco, enquanto que a saturação por potássio na CTC, na mesma camada, mostrou um efeito positivo. No entanto a CTC e a SB dessa camada tiveram uma relação direta com o suco.

O teor de cálcio na camada 20 a $40 \mathrm{~cm}$ mostrou-se relacionada negativamente com o rendimento do suco, já a saturação por cálcio na CTC da mesma camada mostrou se relacionada positivamente

O alumínio trocável em profundidade mostrou-se relacionado diretamente com o rendimento de suco. Os teores desse elemento não são elevados nessa camada dos solos amostrados. E essa relação somente é válida dentro do intervalo de valores das amostras.

$\mathrm{Na}$ camada 0 a $20 \mathrm{~cm}$, o cobre teve efeito negativo sobre o rendimento de suco. $\mathrm{Na}$ camada $20 \mathrm{a} 40 \mathrm{~cm}$ o boro teve efeito positivo e o ferro negativo.

A relação $\mathrm{Ca} / \mathrm{K}$ (na profundidade 0 a $20 \mathrm{~cm}$ ) indica que quanto menor, maior o rendimento de suco. A relação $\mathrm{Ca} / \mathrm{Mg}$ (na profundidade de $20 \mathrm{a} 40 \mathrm{~cm}$ ) indica que quanto maior, maior será o rendimento do suco, sendo que o teor de cálcio confirma isso nessa camada.

\subsubsection{Porcentagem de sólidos solúveis do suco (Brix)}

A equação obtida para a porcentagem de sólidos solúveis do suco possui 17 variáveis, sendo que dessas, 7 são referentes à profundidade 0 a $20 \mathrm{~cm}$ e 10 à profundidade $20 \mathrm{a} 40 \mathrm{~cm}, \mathrm{e}$ explica $94,3 \%$ das variações observadas. Na tabela 19 do apêndice é apresentado o quadro da 
análise de variância e os coeficientes de determinação e o coeficiente ajustado e na tabela 20 do apêndice está a equação escolhida e o teste $\mathrm{F}$ de cada variável (as letras A e B que seguem cada variável indicam as profundidades 0 a 20 e 20 a $40 \mathrm{~cm}$, respectivamente).

$$
\begin{array}{r}
\text { Brix (\%) }=10,423-0,025 \mathrm{P}_{\mathrm{B}}-0,401 \mathrm{pH}_{\mathrm{A}}+1,954 \mathrm{~K}_{\mathrm{B}}-0,335 \mathrm{Mg}_{\mathrm{B}}+0,338 \mathrm{~V}_{\mathrm{B}}-2,677 \mathrm{~B}_{\mathrm{A}}- \\
0,182 \mathrm{Cu}_{\mathrm{A}}-1,030 \mathrm{Cu}_{\mathrm{B}}+0,037 \mathrm{Fe}_{\mathrm{A}}-0,157 \mathrm{Mn}_{\mathrm{A}}+0,401 \mathrm{Mn}_{\mathrm{B}}-0,241 \mathrm{Zn}_{\mathrm{B}}+0,306 \mathrm{Ca} / \mathrm{K}_{\mathrm{B}}- \\
0,305 \mathrm{Mg} / \mathrm{K}_{\mathrm{B}}+0,444 \mathrm{Ca} / \mathrm{Mg}_{\mathrm{A}}-0,423 \mathrm{Ca}_{\mathrm{CTC}}-0,207 \mathrm{~K}_{\mathrm{CTC} A}
\end{array}
$$

$\mathrm{Na}$ camada $20 \mathrm{a} 40 \mathrm{~cm}$, o fósforo e o magnésio relacionaram-se negativamente com o Brix, e o potásso positivamente, o mesmo ocorrendo com a saturação por bases nessa camada. A saturação por cálcio na CTC também relaciona-se negativamente, mostrando concordância com os teores de potássio e magnésio nessa camada.

$\mathrm{O} \mathrm{pH}$ da camada superficial relacionou-se inversamente com a porcentagem de sólidos solúveis de suco. $\mathrm{O}$ boro na superficie atuou de modo a reduzir o Brix. O cobre em ambas as profundidades do solo relacionaram-se negativamente com a porcentagem de sólidos solúveis. $\mathrm{O}$ ferro na camada superficial relacionou-se positivamente e o manganês negativamente. No entanto, na camada inferior, esse micronutriente teve efeito contrário. $O$ zinco na camada 20 a $40 \mathrm{~cm}$ atuou de modo negativo.

$\mathrm{Na}$ camada 0 a $20 \mathrm{~cm}$ a saturação por potássio na CTC relacionou-se negativamente com a porcentagem de sólidos solúveis de suco. Já a relação $\mathrm{Ca} / \mathrm{Mg}$ mostrou-se positiva.

\subsubsection{Acidez total}

A equação obtida para a acidez total possui 18 variáveis, sendo que dessas, 8 são referentes à profundidade 0 a $20 \mathrm{~cm}$ e 10 à profundidade 20 a $40 \mathrm{~cm}$, e explica $97,1 \%$ das variações observadas. Na tabela 21 do apêndice é apresentado o quadro da análise de variância e os coeficientes de determinação e o coeficiente ajustado e na tabela 22 do apêndice está a equação escolhida e o teste $\mathrm{F}$ de cada variável (as letras A e B que seguem cada variável indicam as profundidades 0 a 20 e 20 a $40 \mathrm{~cm}$, respectivamente). 
Acidez $(\%)=-0,627-0,006 \mathrm{P}_{\mathrm{B}}+0,012 \mathrm{M} \cdot \mathrm{O}_{\mathrm{A}}-1,332 \mathrm{~K}_{\mathrm{B}}+0,254 \mathrm{Mg}_{\mathrm{B}}-0,027 \mathrm{SB}_{\mathrm{A}}+0,024$ $\mathrm{CTC}_{\mathrm{B}}+0,020 \mathrm{~V}_{\mathrm{A}}-0,092 \mathrm{~V}_{\mathrm{B}}-0,027 \mathrm{~m}_{\mathrm{A}}+0,015 \mathrm{~m}_{\mathrm{B}}+0,408 \mathrm{~B}_{\mathrm{A}}-0,222 \mathrm{Cu}_{\mathrm{B}}-0,024 \mathrm{Mn}_{\mathrm{A}}+$ $0,044 \mathrm{Mn}_{\mathrm{B}}+0,140 \mathrm{Zn}_{\mathrm{A}}+0,089 \mathrm{Ca}_{\text {СTC B }}-0,018 \mathrm{~K}_{\text {СтC A }}+0,943 \mathrm{~K}_{\text {СтC B }}$

$O$ fósforo na camada inferior teve relação inversa com a acidez . O mesmo foi demonstrado por WEIR et al. (1978), segundo os quais, a acidez do suco reduziu com aumentos nas doses de fósforo.

A matéria orgânica na camada $0 \mathrm{a} 20 \mathrm{~cm}$ teve um efeito positivo sobre a acidez. A saturação por bases na camada superficial relacionou-se diretamente, já na camada subsuperfícial ocorreu um efeito contrário. Porém observando-se o efeito da saturação por alumínio nas camadas pode se esclarecer o que ocorreu, pois na primeira camada a saturação por alumínio teve efeito inverso sobre a acidez, e na camada inferior teve efeito direto.

A soma de bases na superfície relacionou-se inversamente com a acidez. Enquanto que a CTC e o magnésio na superficie tiveram um efeito positivo. $O$ teor de potássio na camada 20 a 40 $\mathrm{cm}$ apresentou efeito negativo, e a saturação por potássio na superfície foi negativa. A saturação por cálcio na camada inferior afetou diretamente a acidez.

$\mathrm{O}$ comportamento dos micronutrientes na camada superficial foram positivos para o boro $\mathrm{e}$ o zinco e negativo para o manganês, que no entanto teve efeito positivo na camada $20 \mathrm{a} 40 \mathrm{~cm}$.

\subsubsection{Relação sólidos solúveis/acidez}

A equação obtida para a relação sólido solúveis/acidez possui 17 variáveis, sendo que dessas 10 são referentes à profundidade de $0 \mathrm{a} 20 \mathrm{~cm}$ e 17 à profundidade de $20 \mathrm{a} 40 \mathrm{~cm}$, e explica $94,5 \%$ das variações observadas. Na tabela 23 do apêndice está o quadro da análise de variância e os coeficientes de determinação e o coeficiente ajustado e na tabela 24 do apêndice está a equação escolhida e o teste $\mathrm{F}$ de cada variável (as letras A e B que seguem cada variável indicam as profundidades 0 a 20 e 20 a $40 \mathrm{~cm}$, respectivamente). 
Ratio $=2,473+0,097$ M.O. $\cdot_{\mathrm{A}}-0,143 \mathrm{M} \cdot \mathrm{O}_{\mathrm{B}}+2,791 \mathrm{pH}_{\mathrm{A}}+1,603 \mathrm{~K}_{\mathrm{B}}-0,493 \mathrm{Mg}_{\mathrm{B}}+0,125 \mathrm{SB}_{\mathrm{A}}-$ $0,227 \mathrm{~V}_{\mathrm{A}}+0,104 \mathrm{~m}_{\mathrm{A}}-0,073 \mathrm{~m}_{\mathrm{B}}-2,357 \mathrm{~B}_{\mathrm{A}}-0,620 \mathrm{Cu}_{\mathrm{A}}+0,458 \mathrm{Cu}_{\mathrm{B}}+0,29 \mathrm{Fe}_{\mathrm{A}}-0,288$ $\mathrm{Zn}_{\mathrm{B}}-0,061 \mathrm{Ca} / \mathrm{K}_{\mathrm{A}}+0,396 \mathrm{Mg} / \mathrm{K}_{\mathrm{B}}+0,008 \mathrm{Ca}_{\mathrm{CTC}} \mathrm{A}$

A matéria orgânica apresentou um efeito diferenciado sobre o ratio do suco, ou seja, na camada superficial teve uma relação direta com esse parâmetro de qualidade e na camada inferior teve uma relação inversa. $\mathrm{O} \mathrm{pH}$ na camada superior apresentou efeito positivo.

A soma de bases e a saturação por bases da camada 0 a $20 \mathrm{~cm}$ apresentaram um comportamento inverso, enquanto que na primeira houve um efeito positivo sobre o ratio e a segunda um efeito negativo.

O caso do efeito positivo da saturação por alumínio da camada superfícial encaixa-se no que já foi discutido, ou seja, os valores observados são pequenos e a relação somente é válida dentro dos limites estudados. Na outra profundidade, a saturação por alumímio teve comportamento inverso ao ratio.

Na profundidade 0 a $20 \mathrm{~cm}$, os fatores boro e cobre apresentaram influência negativa na equação, enquanto o ferro teve efeito positivo. Na outra profundidade o cobre teve efeito positivo $\mathrm{e}$ o zinco negativo.

A relação $\mathrm{Mg} / \mathrm{K}$ na camada 20 a $40 \mathrm{~cm}$ teve efeito positivo sobre o ratio, sendo que os teores de potássio e magnésio apresentaram efeito positivo e negativo respectivamente, confirmando a tendência. A saturação por cálcio na camada superfícial relacionou-se positivamente com o ratio. 


\subsubsection{Análise de folhas}

Em cada subítem são apresentadas as equações obtidas através do método do $\mathrm{R}^{2}$ máximo, utilizando as 30 observações e as 77 variáveis referentes aos resultados das análises de folhas e seus coeficientes de determinação. A escolha das equações foi sempre por aquela que apresentasse maior $\mathrm{R}^{2}$, menor Quadrado Médio do Resíduo, porém com os Graus de Liberdade do Resíduo maior que 10.

\subsubsection{Produção Relativa (PR)}

A equação obtida para a produção relativa possui 18 variáveis, e explica $94,5 \%$ das variações na PR. Na tabela 25 do apêndice é apresentado o quadro da análise de variância e os coeficientes de determinação e o coeficiente ajustado e na tabela 26 do apêndice está a equação escolhida $\mathrm{e}$ o teste $\mathrm{F}$ de cada variável.

$$
\begin{aligned}
& \mathrm{PR}(\%)=-561,140-44,499 \mathrm{~S}+13,182 \mathrm{Cu}+1,822 \mathrm{Mg}^{2}+0,018 \mathrm{~B}^{2}-0,070 \mathrm{Cu}^{2}-0,007 \mathrm{Zn}^{2}- \\
& 10,977 \mathrm{~N} / \mathrm{S}+685,094 \mathrm{~N} / \mathrm{Cu}-38,886 \mathrm{~N} / \mathrm{Mn}+132,256 \mathrm{P} / \mathrm{Mg}-2566,835 \mathrm{P} / \mathrm{Zn}+1009,360 \\
& \mathrm{~K} / \mathrm{Fe}+24,918 \mathrm{Ca} / \mathrm{Mn}+430,281-191,438 \mathrm{Mg} / \mathrm{Mn}+218,279 \mathrm{~S} / \mathrm{Mn}-55,955 \mathrm{~B} / \mathrm{Cu}+ \\
& 26,129 \mathrm{Mn} / \mathrm{Zn}
\end{aligned}
$$

De acordo com a equação obtida para a produção relativa em relação à análise de folha, observa-se que o enxofre teve um efeito negativo sobre a produção, entretanto MALAVOLTA \& VIOLANTE NETTO (1988) relataram que os aumentos nos teores foliares do nutriente traduziramse em aumentos na produção. A relação $\mathrm{S} / \mathrm{Mn}$ mostrou ser positiva para a produção relativa.

Os teores de cobre e o quadrado do teor $\left(\mathrm{Cu}^{2}\right)$ afetaram a $\mathrm{PR}$ positiva e negativamente, respectivamente, mostrando com isso que os teores mais baixos de cobre aumentaram a PR, porém, com o teor tornando-se mais alto, houve um decréscimo na produção. A relação N/Cu afetou diretamente a PR.

De acordo com SMITH (1966) e RODRIGUEZ (1991), as plantas cítricas tem uma alta exigência em magnésio. A equação ilustra essa exigência, pois o quadrado do teor de nutriente 
$\left(\mathrm{Mg}^{2}\right)$ teve um efeito positivo na $\mathrm{PR}$, já a relação $\mathrm{Mg} / \mathrm{Mn}$ foi negativa. Para SMITH (1966) e EMBLETON et al. (1978) os teores de magnésio na planta tendem a elevar os teores foliares de manganês, pois esse nutriente é deslocado das raízes para a parte aérea. A relação $\mathrm{P} / \mathrm{Mg}$ afetou positivamente a PR.

$\mathrm{O}$ quadrado dos teores de boro e zinco atuaram positiva e negativamente sobre a $\mathrm{PR}$, respectivamente. Porém LABANAUSKAS et al. (1963) observaram que pulverizações com zinco em plantas levemente deficientes neste nutriente não tiveram respostas em termos de produção de frutos. A relação $\mathrm{P} / \mathrm{Zn}$, que foi negativa em relação à $\mathrm{PR}$, mostra que os aumentos do fósforo foliar tende a reduzir o zinco, conforme foi apresentado por EMBLETON et al. (1975).

As relações do nitrogênio com o enxofre e com manganês apresentaram efeitos negativos sobre a produção relativa dos pomares estudados. De acordo com EMBLETON et al. (1978), aumentos nos teores de nitrogênio tendem a reduzir os teores de enxofre na planta, isso favorece o efeito negativo da relação entre eles, pois com uma relação alta reduz-se o enxofre, e este pode atingir conteúdos que aproximam-se da deficiência. $\mathrm{O}$ mesmo efeito ocorreu entre os teores de nitrogênio e de manganês, de acordo com SMITH (1966).

A relação do nitrogênio com o cobre teve efeito positivo, reafirmando que os teores mais baixos de cobre são mais desejáveis que os teores elevados.

As relações entre $\mathrm{P} / \mathrm{Mg}, \mathrm{K} / \mathrm{Fe}, \mathrm{Ca} / \mathrm{Mn}$ e $\mathrm{Mn} / \mathrm{Zn}$ foram diretamente relacionadas com a $\mathrm{PR}$, e indiretamente a relação $\mathrm{B} / \mathrm{Cu}$.

\subsubsection{Massa média dos frutos}

A equação obtida para a massa média dos frutos possui 17 variáveis, e explica $95,2 \%$ das variações observadas. Na tabela 27 do apêndice é apresentado o quadro da análise de variância e os coeficientes de determinação e o coeficiente ajustado e na tabela 28 do apêndice está a equação escolhida e o teste $\mathrm{F}$ de cada variável. 
Fruto $(\mathrm{g})=-172,589-57,122 \mathrm{~S}+5,676 \mathrm{Mg}^{2}+179,565-12085,219 \mathrm{P} / \mathrm{Fe}-139,087 \mathrm{~K} / \mathrm{Ca}+7,281$

$\mathrm{Ca} / \mathrm{Mg}+164,410 \mathrm{Ca} / \mathrm{Cu}-607,510 \mathrm{Ca} / \mathrm{Zn}-584,387 \mathrm{Mg} / \mathrm{Cu}+1482,276 \mathrm{Mg} / \mathrm{Zn}+4490,227$

$\mathrm{S} / \mathrm{Cu}-2074,897 \mathrm{~S} / \mathrm{Zn}+262,823 \mathrm{~B} / \mathrm{Fe}+131,578 \mathrm{Cu} / \mathrm{Fe}+325,512 \mathrm{Cu} / \mathrm{Zn}-1,330 \mathrm{Fe} / \mathrm{Mn}+$ $17,805 \mathrm{Fe} / \mathrm{Zn}$

$\mathrm{O}$ quadrado do teor de magnésio $\left(\mathrm{Mg}^{2}\right)$ teve uma relação direta com a massa média dos frutos. A relação do magnésio com o cobre foi negativa em relação à massa média dos frutos, e a relação $\mathrm{Mg} / \mathrm{Zn}$ foi positiva. De acordo com SMITH (1966) existem relações entre os teores desses nutrientes nas plantas cítricas, segundo as quais o magnésio aumenta os teores de manganês e reduz os de cobre na parte aérea.

O teor de enxofre afetou negativamente esse parâmetro dos frutos, já sua relação com o cobre mostrou-se positiva e negativa com o zinco.

$\mathrm{O}$ efeito da relação de $\mathrm{K} / \mathrm{Ca}$ positiva sobre a massa média dos frutos, evidencia a alta exigência de cálcio dessa cultura. $\mathrm{O}$ antagonismo existente entre esses cátions que já haviam sido relatados por NAGAI et al. (1975) e WEIR (1969). MALAVOLTA et al. (1989) mostraram que existe um efeito antagônico do cálcio sobre a absorção de cobre. E a relação entre esses nutrientes nessa equação foi positiva. E segundo os mesmos autores, existe uma inibição competitiva entre o zinco e o cálcio, porém a relação entre eles é negativa, mostrando que o zinco é necessário para o aumento nos frutos. JONES (1961) relatou alguns trabalhos que afirmaram a mesma tendência.

As relações de N/B e B/Fe foram diretamente relacionadas com a massa médias dos frutos . As relações de cobre com o ferro e com o zinco foram relacionadas posteriormente com a massa dos frutos. $\mathrm{E}$ as relações $\mathrm{Fe} / \mathrm{Mn}$ e $\mathrm{Fe} / \mathrm{Zn}$ foram negativas e positivas respectivamente. Sobre o efeito do cobre em reduzir os teores de zinco, EMBLETON et al. (1976) citam que há um efeito benéfico pois favorece a relação observada entre os dois nutrientes e o peso médio dos frutos.

\subsubsection{Espessura da casca}

A equação obtida para a espessura da casca possui 18 variáveis, e explica $98,7 \%$ das variações observadas. Na tabela 29 do apêndice é apresentado o quadro da análise de variância e os 
coeficientes de determinação e o coeficiente ajustado e na tabela 30 do apêndice está a equação escolhida e o teste $\mathrm{F}$ de cada variável.

$$
\begin{aligned}
& \text { Casca }(\mathrm{mm})=153,974+6,506 \mathrm{~N}-3,225 \mathrm{~K}-0,002 \mathrm{Zn}^{2}-12,712 \mathrm{~N} / \mathrm{P}+313,106 \mathrm{~N} / \mathrm{Ca}-6,930 \\
& \mathrm{~N} / \mathrm{Mg}-49,367 \mathrm{~N} / \mathrm{B}-5326,806 \mathrm{P} / \mathrm{Cu}-289,725 \mathrm{P} / \mathrm{Mn}+9,721 \mathrm{Ca} / \mathrm{Mg}+312,841 \mathrm{Ca} / \mathrm{Cu}- \\
& 468,576 \mathrm{Ca} / \mathrm{Fe}-160,422 \mathrm{Ca} / \mathrm{Zn}-12,288 \mathrm{Mg} / \mathrm{S}+1227,629 \mathrm{Mg} / \mathrm{B}+62,131 \mathrm{Mg} / \mathrm{Mn}+ \\
& 66,143 \mathrm{~B} / \mathrm{Zn}+272,816 \mathrm{Cu} / \mathrm{Fe}
\end{aligned}
$$

De acordo com a equação, o teor de nitrogênio não está diretamente relacionado com a espessura da casca. EMBLETON et al. (1975) e WEIR et al. (1978) haviam notado o mesmo efeito. A relação N/P foi negativa em relação à casca, o que é favorecido pelo antagonismo existente entre os dois nutrientes nas folhas dos citros. De acordo com SMITH (1966), o efeito contrário do nitrogênio é muito forte sobre o fósforo, porém o inverso não é tão evidente. A relação de N/Ca foi positiva para a espessura de casca, ao contrário da relação N/Mg.

Associando-se a essas, a relação positiva $\mathrm{Ca} / \mathrm{Mg}$ evidencia o papel do cálcio no espessamento da casca. Isso talvez ocorra devido às funções estruturais do cálcio, na formação de pectatos (MALAVOLTA et al. 1989). A relação N/B foi negativa, comprovando indiretamente as observações de JONES (1961), segundo o qual, existe uma tendência ao espessamento do albedo em frutos cítricos de plantas deficientes em boro.

O teor de potássio afetou negativamente a espessuara da casca, discordando assim de EMBLETON et al. (1975) e WEIR et al. (1978). Para REITZ \& KOO (1960), o creasing ocorre em frutos com casca fina, que tenham recebido altas doses de nitrogênio e baixas de potássio.

Pela equação, as relações de fósforo com o cobre e manganês são negativas mostrando que com a redução nos seus valores há uma tendência do aumento na espessura. EMBLETON et al. (1975) e WEIR et al. (1978) haviam relatado uma pequena diminuição na espessura da casca, com o aumento do fósforo, confirmando indiretamente as relações anteriores.

A relação entre cálcio e cobre foi positiva para a espessura da casca, que é facilitada pela relação antagônica (MALAVOLTA et al. 1989) que existe entre eles. Porém, as outras relações do cálcio, com o ferro e com o zinco foram negativas. 
As relações $\mathrm{Mg} / \mathrm{S}, \mathrm{Mg} / \mathrm{B}$ e $\mathrm{Mg} / \mathrm{Mn}$ foram negativa para a primeira e positiva para as duas últimas. Outras duas relações diretamente relacionadas com a espessura de casca foram as do $\mathrm{B} / \mathrm{Zn}$ e do $\mathrm{Cu} / \mathrm{Fe}$.

\subsubsection{Rendimento de suco}

A equação obtida para o rendimento de suco possui 16 variáveis, e explica $98,8 \%$ das variações observadas. Na tabela 31 do apêndice é apresentado o quadro da análise de variância e os coeficientes de determinação e o coeficiente ajustado e na tabela 32 do apêndice está a equação escolhida e o teste $\mathrm{F}$ de cada variável.

Suco $(\%)=52,377+0,475 \mathrm{Cu}+0,013 \mathrm{~N}^{2}-0,002 \mathrm{Cu}^{2}-0,0002 \mathrm{Fe}^{2}+0,0004 \mathrm{Zn}^{2}-0,223 \mathrm{~N} / \mathrm{P}$ -

$19,873 \mathrm{P} / \mathrm{S}+9,751 \mathrm{P} / \mathrm{Mn}+0,662 \mathrm{~K} / \mathrm{S}-4,951 \mathrm{~K} / \mathrm{B}+0,298 \mathrm{Ca} / \mathrm{Mg}+3,356 \mathrm{Mg} / \mathrm{S}-0,402$

$\mathrm{B} / \mathrm{Mn}-80,193 \mathrm{Cu} / \mathrm{Fe}+1,131 \mathrm{Cu} / \mathrm{Mn}+5,908 \mathrm{Mn} / \mathrm{Zn}$

O teor de cobre teve um efeito positivo sobre o rendimento de suco, no entanto o quadrado de teor de cobre $\left(\mathrm{Cu}^{2}\right)$ teve um efeito contrário, demonstrando que são desejáveis teores não muito elevados do nutriente, para a maximização desse parâmetro. A relação entre o cobre e o ferro foi negativa, e pode ser confirmada com as observações de JONES (1961) e ALVA \& CHEN (1995), sendo que o cobre em excesso, pode induzir à deficiência de ferro e, através da equação, pode-se observar que houve uma redução na porcentagem de suco.

$\mathrm{O}$ quadrado do teor de ferro $\left(\mathrm{Fe}^{2}\right)$ afetou negativamente o rendimento de suco. A relação entre o cobre e o manganês foi positiva para o rendimento do suco.

WEIR et al. (1978) associaram a diminuição da porcentagem de suco com o aumento do nitrogênio foliar, porém pela equação, o quadrado do teor de nitrogênio $\left(\mathrm{N}^{2}\right)$ relacionou-se diretamente como rendimento de sucos. A relação N/P atuou negativamente, indicando que os aumentos nos rendimentos de suco através do aumento dos teores foliares de nitrogênio devem ser acompanhados por aumentos nos teores de fósforo.

A relação entre o fósforo e o enxofre foi negativa para o rendimento de suco, os teores de enxofre devem ser aumentados em relação ao fósforo, para garantir altos rendimentos. A relação 
entre o fósforo e o manganês foi positiva. Ocorreu um aumento no rendimento de suco com um aumento nas relações $\mathrm{Ca} / \mathrm{Mg}$ e $\mathrm{Mg} / \mathrm{S}$. Já a relação $\mathrm{K} / \mathrm{S}$ foi positiva e a $\mathrm{K} / \mathrm{B}$ foi negativa.

$\mathrm{O}$ quadrado do teor de zinco $\left(\mathrm{Zn}^{2}\right)$ foi diretamente relacionado com o rendimento de suco, e o mesmo foi observado por LANTHASA \& BHATTACHARYYA (1991). A relação $\mathrm{Mn} / \mathrm{Zn}$ também foi positiva, porém, a relação $\mathrm{B} / \mathrm{Mn}$ teve um efeito negativo sobre o rendimento de suco. JONES (1961) afirmou que frutos originários de plantas deficientes em boro continham pouco suco.

\subsubsection{Porcentagem de sólidos solúveis do suco (Brix)}

A equação obtida para a porcentagem de sólidos solúveis do suco possui 17 variáveis e explica $97,9 \%$ das variações observadas. Na tabela 33 do apêndice é apresentado o quadro da análise de variância e os coeficientes de determinação e o coeficiente ajustado e na tabela 34 do apêndice está a equação escolhida e o teste $\mathrm{F}$ de cada variável.

Brix (\%) $=6,508-1,586 \mathrm{Mg}+1,874 \mathrm{~S}-0,00001 \mathrm{Fe}^{2}+2,108 \mathrm{~N} / \mathrm{K}-23,852 \mathrm{P} / \mathrm{K}-15,652 \mathrm{P} / \mathrm{Mg}+$ $19,164 \mathrm{P} / \mathrm{S}-92,185 \mathrm{P} / \mathrm{Zn}+1,436 \mathrm{~K} / \mathrm{Mg}-1,668 \mathrm{~K} / \mathrm{S}+75,325 \mathrm{~K} / \mathrm{Fe}+0,463 \mathrm{~K} / \mathrm{Mn}+16,388$ $\mathrm{Mg} / \mathrm{Cu}+106,032 \mathrm{~S} / \mathrm{B}-539,537 \mathrm{~S} / \mathrm{Fe}+1,882 \mathrm{~B} / \mathrm{Zn}-1,237 \mathrm{Cu} / \mathrm{Zn}$

Para QUAGGIO et al. (1993), os aumentos no Brix do suco são acompanhados de aumentos nos teores foliares de magnésio. De acordo com a equação porém, o teor de magnésio teve uma relação inversa com o Brix, e a relação $\mathrm{Mg} / \mathrm{Cu}$ uma relação direta.

O enxofre teve uma relação direta com o Brix, e as relações do nutriente com o boro e com o ferro teve relações direta e inversa respectivamente. O quadrado do teor de $\mathrm{Fe}\left(\mathrm{Fe}^{2}\right)$ também teve uma relação inversa.

A relação $\mathrm{N} / \mathrm{K}$ influenciou positivamente a porcentagem de sólidos solúveis do suco. $\mathrm{Na}$ literatura existe controvérsia sobre o efeito do nitrogênio sobre os sólidos solúveis. STEWART \& WHEATON (1965) e REESE \& KOO (1975) afirmaram que o efeito foi positivo, no entanto, para REITZ \& KOO (1960) o efeito foi negativo. 
As relações entre o fósforo e o potássio, o magnésio e o zinco foram negativas, enquanto que a relação $\mathrm{P} / \mathrm{S}$ foi positiva para a porcentagem de sólidos solúveis do suco.

WEIR (1969) relatou que o potássio foi o cátion mais fortemente antagônico. A relação $\mathrm{K} / \mathrm{Mg}$ teve efeito positivo sobre o Brix e é favorecida por esse antagonismo entre os nutrientes. $\mathrm{O}$ mesmo efeito positivo foi observado para $\mathrm{K} / \mathrm{Fe}$ e $\mathrm{K} / \mathrm{S}$.

A relação $\mathrm{B} / \mathrm{Zn}$ atuou positivamente e o $\mathrm{Cu} / \mathrm{Zn}$ negativamente na porcentagem de sólidos solúveis do suco, apenas essa última relação está de acordo com LANGTHASA \& BHATTACHARYYA (1991), que observaram aumentos nos sólidos solúveis com o fornecimento de zinco via foliar.

\subsubsection{Acidez total}

A equação obtida para a acidez total possui 19 variáveis e explica 95,3\% das variações observadas. $\mathrm{Na}$ tabela 35 do apêndice é apresentado o quadro da análise de variância e os coeficientes de determinação e o coeficiente ajustado e na tabela 36 do apêndice está a equação escolhida e o teste $\mathrm{F}$ de cada variável.

Acidez $(\%)=-0,765+0,177 \mathrm{~S}+0,018 \mathrm{~B}-0,005 \mathrm{Zn}-0,0001 \mathrm{~B}^{2}+0,0001 \mathrm{Cu}^{2}-0,046 \mathrm{~N} / \mathrm{Mg}+$ $0,077 \mathrm{~N} / \mathrm{S}+1,296 \mathrm{~N} / \mathrm{Fe}+24,231 \mathrm{P} / \mathrm{B}-0,144 \mathrm{~K} / \mathrm{S}+13,782 \mathrm{~K} / \mathrm{Fe}+0,415 \mathrm{Ca} / \mathrm{Cu}-33,092$ $\mathrm{Mg} / \mathrm{Fe}-3,487-0,860 \mathrm{~S} / \mathrm{Mn}-4,224 \mathrm{~S} / \mathrm{Zn}+0,122 \mathrm{~B} / \mathrm{Mn}-0,021 \mathrm{Cu} / \mathrm{Mn}+0,005 \mathrm{Fe} / \mathrm{Mn}$

O teor de boro estava diretamente relacionado com a acidez do suco, enquanto que o quadrado do teor $\left(\mathrm{B}^{2}\right)$ estava inversamente relacionado, desse modo, teores mais elevados do nutriente tendem a reduzir a acidez, concordando com SMITH (1955), que observou pequenos decréscimos no teor de ácido cítrico e na vitamina $\mathrm{C}$ do suco, com a elevacão dos teores de boro foliar. A relação $\mathrm{B} / \mathrm{Mn}$ foi diretamente relacionada com a acidez.

O teor de enxofre afetou diretamente a acidez, enquanto que as relações desse nutriente com o manganês e o zinco afetaram negativamente.

O teor de zinco teve uma relação inversa com a acidez, no entanto, LABANAUSKAS et al. (1963) e LANGTHASA \& BHATTACHARYYA (1991) observaram uma relação contrária. 
O quadrado do teor de cobre $\left(\mathrm{Cu}^{2}\right)$ teve efeito positivo sobre a acidez, JONES (1961), relatou que teores excessivos de cobre podem elevar muito a acidez total do suco. A relação $\mathrm{Ca} / \mathrm{Cu}$ também teve o mesmo efeito sobre a acidez.

A relação N/S foi relacionada diretamente, podendo então ser favorecida pelo efeito dos teores de nitrogênio sobre os de enxofre nas plantas cítricas. Segundo EMBLETON et al. (1978) há decréscimos nos teores de enxofre com os aumentos das doses de nitrogênio. A relação de $\mathrm{N} / \mathrm{Fe}$ também foi positiva para a acidez.

A relação P/B foi positiva para a acidez. EMBLETON et al. (1978) relatam que essa relação é favorecida pelo comportamento do fósforo em reduzir o boro nos citros.

As relações do potássio com o enxofre e com o ferro foram respectivamente negativa $\mathrm{e}$ positiva para a acidez do suco. As relações de magnésio com o ferro e com o zinco são indiretamente relacionadas com acidez do suco, e também a relação de $\mathrm{Fe} / \mathrm{Mn}$. Na relação $\mathrm{Cu} / \mathrm{Mn}$, observou-se o inverso.

\subsubsection{Relação sólidos solúveis/acidez}

A equação obtida para a relação sólidos solúveis/acidez possui 18 variáveis, e explica 98,3\% das variações observadas. Na tabela 37 do apêndice é apresentado o quadro da análise de variância e os coeficientes de determinação e o coeficiente ajustado e na tabela 38 do apêndice está a equação escolhida e o teste $\mathrm{F}$ de cada variável.

$$
\begin{aligned}
\text { Ratio }= & 53,712-0,076 \mathrm{~B}+0,217 \mathrm{Cu}-0,125 \mathrm{Fe}+1,535 \mathrm{Mg}^{2}+1,643 \mathrm{~N} / \mathrm{Mg}+22,487 \mathrm{~N} / \mathrm{Cu}- \\
& 20,870 \mathrm{~N} / \mathrm{Zn}-46,673 \mathrm{P} / \mathrm{Mg}-4,756 \mathrm{P} / \mathrm{S}-36,433 \mathrm{~K} / \mathrm{Ca}+3,480 \mathrm{~K} / \mathrm{Mg}-12,192 \mathrm{Ca} / \mathrm{Zn}- \\
& 212,619 \mathrm{Mg} / \mathrm{Cu}-148,750 \mathrm{Mg} / \mathrm{Fe}+134,090 \mathrm{~S} / \mathrm{Zn}+3,825 \mathrm{~B} / \mathrm{Cu}-115,350 \mathrm{Cu} / \mathrm{Fe}+14,998 \\
& \mathrm{Cu} / \mathrm{Zn}
\end{aligned}
$$

Os teores de boro foram diretamente relacionados com o ratio, porém a relação $\mathrm{B} / \mathrm{Cu}$ foi diretamente relacionada. O mesmo ocorreu com o teor de cobre e portanto, de acordo com JONES (1961), que relata que o excesso de cobre eleva a acidez. A elevação de acidez faz com que haja uma redução no ratio. 
A relação $\mathrm{Cu} / \mathrm{Fe}$ foi negativa para a relação sólidos solúveis/acidez, e de acordo com ALVA \& CHEN (1995) essa relação é favorecida pelo antagonismo existente entre os dois micronutrientes. Porém, o teor de ferro influenciou negativamente este fator. Já a relação $\mathrm{Cu} / \mathrm{Zn}$ teve efeito positivo.

O quadrado do teor de magnésio $\left(\mathrm{Mg}^{2}\right)$ foi positivo, já as relações com cobre e ferro foram negativas.

A relação $\mathrm{K} / \mathrm{Ca}$ foi inversa ao ratio, no entanto, a relação $\mathrm{K} / \mathrm{Mg}$ foi diretamente relacionada com esse fator de qualidade.

As relações N/Mg e N/Cu tiveram efeito positivo sobre o ratio, enquanto que a relação N/Zn apresentou efeito negativo.

As relações do fósforo com o magnésio e com o enxofre foram negativas. De acordo com EMBLETON et al. (1975), o acréscimo no fósforo foliar provoca aumento na relação de sólidos solúveis/acidez. Portanto, os teores de magnésio e enxofre na planta deveriam ser incrementados, com o objetivo de aumentar o ratio.

A relação do cálcio com o zinco foi inversamente relacionada com o ratio. E a relação $\mathrm{S} / \mathrm{Zn}$ apresentou relação direta. 


\section{CONCLUSÕES}

Nas condições em que esse trabalho foi realizado e, de acordo com os resultados obtidos, pode-se concluir que:

- O método de faixas para a interpretação da fertilidade do solo e do estado nutricional apenas distribuiu as amostras dentro de classes, porém sem considerar suas interações com outros nutrientes ou propriedades do solo e não permitindo determinar-se sua relação com a produtividade e a qualidade dos frutos cítricos;

- A regressão linear múltipla, através do método do $\mathrm{R}^{2}$ máximo, possibilitou selecionar-se as variáveis das análises de solo e de folhas mais relacionadas com a produtividade e a qualidade dos frutos;

- A importância da amostragem do solo na profundidade 20 a $40 \mathrm{~cm}$ para a cultura dos citros foi evidenciada pelas equações de Produção Relativa, massa média dos frutos, rendimento de 
suco, porcentagem de sólidos solúveis e acidez total, nas quais as variáveis relativas à essa profundidade foram mais freqüentemente incluídas que as variáveis da profundidade $0 \mathrm{a} 20 \mathrm{~cm}$;

- As variáveis da profundidade 0 a 20 foram mais freqüentemente incluídas que as variáveis da profundidade 20 a $40 \mathrm{~cm}$ nas equações de espessura da casca e relação sólidos solúveis/acidez;

- A importância das interações entre os nutrientes foi mostrada nas equações de Produção Relativa, massa média dos frutos, espessura da casca, réndimento de suco, porcentagem de sólidos solúveis, acidez total e relação sólidos solúveis/acidez, uma vez que as relações entre eles foram mais freqüentemente incluídas que os teores individuais. 


\section{REFERÊNCIAS BIBLIOGRÁFICAS}

ASSOCIATION OF OFFICIAL ANALYTICAL CHEMISTS. Official methods of analysis. 15. ed. Washington, 1990. 2v, 1278p.

ALVA, A.K. \& CHEN, E.Q. Effects of external cooper concentrations on uptake of trace elements by citrus seedlings. Soil Science, Baltimore, 159(1): 59-64, 1995.

ALVAREZ, V.H. Avaliação da fertilidade do solo (superfícies de resposta - modelos aproximativos para expressar a relação fator-resposta). Viçosa, Imprensa Universitária UFV, 1994. 75p.

ANDERSON, C.A. Effects of phosphate fertilizers on yield and quality of "Valencia" oranges. Proceedings of the Florida State Horticultural Society, Winter Haven, 79: 36-40, 1966.

ANDERSON, C.A. Effects of soil $\mathrm{pH}$ and calcium on yield and quality of young Valencia oranges. Proceedings of the Florida State Horticultural Society, Winter Haven, 84: 4-11, 1971.

ANDERSON, C.A. \& ALBRIGO, L.G. Evaluation of soil testing for magnesium as predictive tools of magnesium status in citrus on dolomited soils. Soil and Crop Science Society of Florida Proceedings, Gainesville, 31: 127-30, 1971. 
BAR-AKIVA, A. \& HAMOU, M. Soil factors influencing fruit quality and mineral composition of leaves of Valencia orange trees. Communications in Soil Science and Plant Analysis, New York, 5(3): 203-12, 1974.

BEAUCLAIR, E.G.F. Relações entre algumas propriedades químicas do solo e a produtividade da cana-de-açúcar (Saccharum spp.), através de regressão linear múltipla. Piracicaba, 1991. 96 p. (Mestrado - Escola Superior de Agricultura "Luiz de Queiroz"/USP).

BEAUCLAIR, E.G.F. Produtividade de cana-de-açúcar em função de alguns macronutrientes presentes no caldo e no solo. Piracicaba, 1994. 98 p. (Doutorado - Escola Superior de Agricultura "Luiz de Queiroz"/USP).

BRASIL. Ministério da Agricultura. Serviço Nacional de Pesquisa Agronômica. Levantamento de reconhecimento dos solos do Estado de São Paulo. Rio de Janeiro, 1960. 634p. (Boletim, 12)

CAETANO, A.A.; RODRIGUEZ, O.; HIROCE, R.; BATAGLIA, O.C. Nutritional survey of forty sweet orange groves in Bebedouro, SP, Brazil. In: INTERNATIONAL CITRUS CONGRESS, São Paulo, 1984. Proceedings. São Paulo, International Society of Citriculture, 1984. p. 151-4.

CANTARELLA, H.; QUAGGIO, J.A.; BATAGLIA, O.C.; RAIJ, B. Response of citrus to NPK fertilization in a network of field trials in São Paulo State, Brazil. In: INTERNATIONAL CITRUS CONGRESS, Acireale, 1992. Proceedings. Acireale, International Society of Citriculture, 1992. p.607-12

CARMELLO, Q.A.C. Regressão linear múltipla aplicada à seleção de variáveis de solo e planta mais relacionadas às produções de milho e amendoim. Piracicaba, 1991. 94p. (Livredocência - Escola Superior de Agricultura "Luiz de Queiroz"/USP)

CHAPMAN, H.D. The mineral nutrition of citrus. In: REUTER, V.; BATCHELOR, L.D.; WEBBER, H., ed. The citrus industry. Berkeley, University of California, 1968. p.127289. 
DASBERG, S. Nitrogen fertilization in citrus orchards. Plant and Soil, Haren, 100(1/3): 1-9, 1987.

DOW, A.I. \& ROBERTS, A.I. Proposal: critical nutrient ranges for crop diagnosis. Agronomy Journal, Madison, 74(2): 401-3, 1982.

DU PLESSIS, S.F. Soil analysis as a necessary complement to leaf analysis for fertilizer advisory purpose. In: INTERNATIONAL CITRUS CONGRESS, Riverside, 1988. Proceedings. Riverside, International Society of Citriculture, 1988. p.15-9.

DU PLESSIS, S.F. \& KOEN, T.J. Effect of nutrition on fruit size of citrus. In: INTERNATIONAL CITRUS CONGRESS, São Paulo, 1984. Proceedings. São Paulo, International Society of Citriculture, 1984. p.148-50.

EMBLETON, T.W.; JONES, W.W.; PLATT, R.G. Plant nutrition and citrus fruit crop quality and yield. Hortscience, Alexandria, 10(1): 48-50, 1975.

EMBLETON, T.W.; JONES, W.W.; KIRKPATRICK, J.D. Influence of aplications of dolomite, potash, and phosphate on quality, grade and composition of Valencia orange fruit. Proceedings of the American Society for Horticultural Science, College Park, 67: 191-201, 1956.

EMBLETON, T.W.; MATSUMURA, M.; KHAN, I.A. Citrus zinc and manganese nutrition revisited. In: INTERNATIONAL CITRUS CONGRESS, Tel Aviv, 1988. Proceedings. Tel Aviv, International Society of Citriculture, 1988. p.681-8.

EMBLETON, T.W.; JONES, W.W.; LABANAUSKAS, C.K.; REUTHER, W. Leaf analysis as a diagnostic tool and guide to fertilization. In: REUTER, V., ed. The citrus industry. Berkeley, University of California, 1973. p.183-210.

EMBLETON, T.W.; JONES, W.W.; PALLARES, C.; PLATT, R.G. Effects of fertilization of citrus on fruit quality and ground water nitrate-pollution potencial. In: INTERNATIONAL CITRUS CONGRESS, Sidney, 1978. Proceedings. Sidney, International Society of Citriculture, 1978. p.280-5. 
GALLO, J.R.; HIROCE, R.; RODRIGUEZ, O.R. Correlação entre composição das folhas e produção e tamanho de frutas de laranjeira Baianinha. Bragantia, Campinas, 25(1): 77-88, 1966.

GALLO, J.R.; MOREIRA, S.; RODRIGUEZ, O.; FRAGA JÚNIOR, C.G. Composição inorgânica das folhas de laranjeira Baianinha, com referência à época de amostragem e adubação química. Bragantia, Campinas, 19(16): 229-46, 1960.

GOEPFERT, C.F.; SALDANHA, E.L.S.; PORTO, O.M. Resposta de laranjeira Valêncià (Citrus sinensis Osbeck) a níveis de fertilizantes, médias de oito safras. Agronomia Sulriograndense, Porto Alegre, 23(2): 203-15, 1987.

GOMES, F.P. Curso de estatística experimental. Piracicaba, Nobel, 1982. 468p.

GOMES, F.P. \& ZEN, S. A produtividade do eucalipto em função das variáveis físicas e químicas do solo. Revista de Agricultura, Piracicaba, 70(2): 139-43, 1995.

GRUPO PAULISTA DE ADUBAÇÃO E CALAGEM PARA CITROS. Recomendação de adubação e calagem para citros no Estado de São Paulo. Laranja, Cordeirópolis, 1994. 27p.

HARDING, R.B. \& CHAPMAN, H.D. Progress report on a study of soil characteristics in highperformance orange orchards in California. Soil Science Society of America Proceedings, Madison, 15: 243-8, 1950.

HIROCE, R. Uso da análise foilar em citros para adubação. In: SIMPÓSIO SOBRE PRODUTIVIDADE DE CITROS, Jaboticabal, 1984. Jaboticabal, Faculdade de Ciências Agrárias e Veterinárias-UNESP, 1984. p.111-26.

HOCKING, R.R. The analysis and selection of variables in linear regression. Biometrics, Releigh, 32(1):1-49, 1976.

HUNZIKER, R.R. The relationship of soil potassium and leaf potassium status to yield of citrus in the Indian River Area. Florida State Horticultural Society Proceedings, Gainesville, 73: 36-69, 1960.

IBRAHIM. H.S. Effects of soil properties on sugarcane yield in Sudam. Experimental Agriculture, London. 14: 273-6, 1978. 
JONES, W.W. Enviromental and cultural factors influencing the chemical composition and physical characters. In: SINCLAIR, W.B., ed. The orange; its biochemistry and physiology. Berkeley, University of California, 1961. p.25-55.

KIEHL, E.J. Manual de edafologia; relações solo-planta. São Paulo, Agronômica Ceres, 1979. $262 \mathrm{p}$.

KOO, R.C.J. \& REESE, R.L. Influence of nitrogen, potassium, and irrigation on citrus fruit quality. In: INTERNATIONAL CITRUS CONGRESS, Riverside, 1977. Proceedings. Riverside, International Society of Citriculture, 1977. p. 34-8.

LABANAUSKAS, C.K.; JONES, W.W.; EMBLETON, T.W. Effects of foliar applications of manganese, zinc, and urea on yield and fruit quality of Valencia oranges, and nutrient concentration in the leaves, peel, and juice. Proceedings of the American Society for Horticultural Science, College Park, 82: 142-53, 1963.

LANGTHASA, S. \& BHATTACHARYYA, R.K. Foliar application of zinc on fruit quality of "Assam Lemon" (Citrus limon Burm.). South Indian Horticulture, Coimbatore, 39(3): 153-5, 1991.

LAIRD, R.J. \& CADY, F.B. Combined analysis of yield data from fertilizer experiments. Agronomy Journal, Madison, 61(6): 829-34, 1969.

MALAVOLTA, E. Conceitos básicos em fertilidade do solo. In: CONGRESSO BRASILEIRO DE CIÊNCIA DO SOLO, Viçosa, 1995. Resumos. Viçosa, Sociedade Brasileira de Ciência do Solo, 1995. p.2200.

MALAVOLTA, E. Leaf analysis in Brazil - present and perspectives. In: INTERNATIONAL CITRUS CONGRESS, Acireale, 1992. Proceedings. Acireale, International Society of Citriculture, 1992. p.570-4.

MALAVOLTA, E. \& VIOLANTE NETTO, A. Nutrição mineral, calagem, gessagem e adubação dos citros. In: SIMPÓSIO DE CITRICULTURA, Jaboticabal, 1988, editado por DONADIO, L.C. Jaboticabal, UNESP / Faculdade de Ciências Agrárias e Veterinárias, 1988. p.233-84 
MALAVOLTA, E.; VITTI, G.C.; OLIVEIRA, S.A. Avaliação do estado nutricional das plantas: princípios e aplicações. Piracicaba, POTAFOS, 1989. 201p.

MARTIN, J.P. \& PAGE, A.L. Influence of exchangeable Ca e $\mathrm{Mg}$ and percentage base saturation on growth of citrus plants. Soil Science, Baltimore, 107: 39-43, 1969.

MARTIN, J.P.; HARDING, R.B.; MURPHY, W.S. Effect of various soil exchangeable cations ratios on growth and chemical composition of citrus plants. Soil Science, Baltimore, 76: 285$95,1953$.

MATTIOLLI, C.H. Métodos de seleção de equações de regressão linear múltipla. Piracicaba, 1983. 104 p. (Mestrado - Escola Superior de Agricultura "Luiz de Queiroz"/USP)

MELSTED, S.W. \& PECK, T.R The Mitscherlich-Bray growth function. In: STELLY, M., ed. Soil testing; correlating and interpreting the analytical results. Madison, American Society of Agronomy, 1977. p.1-18.

NAGAI, V.; IGUE, T.; HIROCE, R. Estudo comparativo das relações entre os nutrientes dosados em folhas de café, citros e milho. Bragantia, Campinas, 34: XXIII-XXVII, 1975.

NELSON, L.A. \& ANDERSON, R.L. Partioning of soil test-crop response probability. In: STELLY, M.,ed. Soil testing; correlating and interpreting the analytical results. Madison, American Society of Agronomy, 1977. p.1-18.

OBREZA, T.A. Evaluation of citrus grove fertility status using soil and leaf tissue testing. Soil and Crop Science Society of Florida Proceedings, Gainesville, 49: 66-9, 1990.

OLIVEIRA, J.B. Solos para citros. In: RODRIGUEZ, O., ed. Citricultura brasileira. Campinas, Fundação Cargill, 1991. p.196-227.

OLIVEIRA, J.B.; JACOMINE, P.K.T.; CAMARGO, M.N. Classes gerais de solos do Brasil: guia auxiliar para seu reconhecimento. Jaboticabal, FINEP, 1992. 201p.

OLIVEIRA, S.A. Avaliação do balanço nutricional no sistema solo-planta. In: CONGRESSO BRASILEIRO DE CIÊNCIA DO SOLO, Goiânia, 1993. Resumos. Goiânia, Sociedade Brasileira de Ciência do Solo, 1993. p.43-4. 
PARKER, E.R. \& JONES, W.W. Orange fruit size in relation to potassium fertilization in a longterm experiment in California. Proceedings of the American Society for Horticultural Science, College Park, 55: 101-13, 1950.

PAULER, B. \& NEUMANN, K.H. On the importance of some characterization of soil fertility by means of multiple linear regression analysis. Bodenkultur, Viena, 40(2): 99-117, 1989.

PLATT, R. Planning and planting the orchard. In: REUTER, V., ed. The citrus industry. Berkeley, University of California, 1973. p.48-97.

PRATT, P.F.; JONES, W.W.; BINGHAM, F.T. Magnesium and potassium contents of orange leaves in relation to exchangeable magnesium and potassium in soil at various depths. Journal of the American Society for Horticultural Science, Alexandria, 70: 245-51, 1957.

QUAGGIO, J.A.; TEÓFILO SOBRINHO, J.; DECHEN, A.R. Magnesium influences on fruit yield and quality of "Valencia" sweet orange on Rangpur lime. In: INTERNATIONAL CITRUS CONGRESS, Acireale, 1992. Proceedings. Acireale, International Society of Citriculture, 1992a. p.633-7.

QUAGGIO, J.A.; TEÓFILO SOBRINHO, J.; DECHEN, A.R. Response to liming of "Valencia" orange tree on Rangpur lime: effects of soil acidity on plant growth and yield. In: INTERNATIONAL CITRUS CONGRESS, Acireale, 1992. Proceedings. Acireale, International Society of Citriculture, 1992b. p.628-32.

RAIJ, B. Calibração de potássio trocável em solos para feijão, algodão e cana-de-açúcar. Ciência e Cultura, São Paulo, 26(6): 575-9, 1974.

RAIJ, B. Fertilidade do solo e adubação. São Paulo, Ceres, Piracicaba; Potafos, 1991. 343p.

RAIJ, B. Modelo quadrático para recomendação de adubação. Piracicaba, 1992. 100p. (Livredocência - Escola Superior de Agricultura "Luiz de Queiroz"/USP)

RAIJ, B. \& QUAGGIO, J.A. Métodos de análise de solo para fins de fertilidade. Campinas, Instituto Agronômico, 1983. 31p. (IAC - Boletim 81). 
REESE, R.L. \& KOO, R.C.J. Effects of $\mathrm{N}$ and $\mathrm{K}$ fertilization on internal and external fruit quality of three major Florida orange cultivars. Journal American Society of Horticultural Science, College Park, 100(4): 425-8, 1975.

REITZ, H.J. \& KOO, P.C.J. Effect of nitrogen and potassium fertilization on yield, fruit quality, and leaf analysis of "Valencia" orange. Proceedings of the American Society for Horticultural Science, College Park, 59: 1-12, 1960.

REUTHER, W. \& SMITH, P.F. Relation of nitrogen, potassium and magnesium to some fruit qualities of "Valencia" orange. Proceedings of American Society for Horticultural Society, College Park, 56: 1-12, 1952.

REUTHER, W. \& SMITH, P.F. Leaf analysis of citrus. In: CHILDERS, N.F. ed. Fruit nutrition, New Brunswick, Rutger University, 1954. p.257-94.

RODRIGUEZ, O. Aspectos fisiológicos, nutrição e adubação dos citros. In: ., ed.

Citricultura brasileira. Campinas, Fundação Cargill, 1991. p.419-75.

RODRIGUEZ, O. \& GALLO, J.R. Levantamento do estado nutricional de pomares cítricos de São Paulo pela análise foliar. Bragantia, Campinas, 20(2): 1183-202, 1961.

RODRIGUEZ, O.\& MOREIRA, S.R. Citrus nutrition - 20 years of experimental results in State of São Paulo, Brazil. In: INTERNATIONAL CITRUS SYMPOSIUM, Riverside, 1969. Proceedings. Riverside, International Society of Citriculture, 1969. p.1579-86.

RODRIGUEZ, O.; ABRAMIDES, E.; POMPEU, J. Reação de laranjeiras Hamlin em latossolo vermelho-amarelo à adubação NPK. In: CONGRESSO BRASILEIRO DE FRUTICULTURA, Viçosa, 1973. Anais. Viçosa, Sociedade Brasileira de Fruticultura, 1973. p.343-60.

RODRIGUEZ, O.; MOREIRA, S.; GALLO, J.R.; TEÓFILO SOBRINHO, J. Nutritional status of citrus trees in São Paulo, Brazil. In: INTERNATIONAL CITRUS CONGRESS, Riverside, 1977. Proceedings. Riverside, International Society of Citriculture, 1977. p.9-12. 
ROY, W.R. The effect of soil applications of manganese on the mineral composition of foliage and maturity of fruit in citrus. Proceedings of Florida State Horticultural Society, Winter Haven, 68: 54-59, 1955.

SARRUGE, J.R. \& HAAG, H.P. Análises químicas em plantas. Piracicaba, ESALQ/ Departamento de Química, 1974. $56 \mathrm{p}$.

SAS INSTITUTE INC. SAS/STAT; user's guide: version 6, 4. ed., Cary, SA, 1989. v.2, 846p.

SMITH, P.F. Relationship of boron level to the production of fruit quality of grapefruit and oranges. Proceedings of Florida State Horticultural Society, Winter Haven, 68: 54-9, 1955.

SMITH, P.F. Citrus nutrition. In: CHILDERS, N.F., ed. Nutrition of fruit crops; temperate to tropical fruit. New Brunswick, Rutgers the State of Universit, 1966. p.174-207.

SMITH, P.F. \& RASMUSSEN, G.K. The relation of K nutrition to citrus fruit size and quality. Proceedings of the American Society for Horticultural Science, College Park, 74: 261-5, 1959.

SMITH, P.F.; REUTHER, W.; GARDNER, F.E. Phosphate fertilizer trials with orange in Florida. II . Effect on some fruit qualities. Proceedings of the American Socity for Horticultural Science, College Park, 53: 85- 90, 1949.

STEWART, I. \& WHEATON, T.A. A nitrogen source and rate study on "Valencia" oranges. Proceedings of Florida State Horticultural Society, Winter Haven, 78: 21-6, 1965.

SUMNER, ME. Interpretation of foliar analysis for diagnostic purposes. Agronomy Journal, Madison, 71(2): 343-71, 1979.

TISDALE, S.L.; NELSON, W.L.; BEATON, J.D. Soil fertility and fertilizers. 4. ed. New York, Macmillan Publ., 1985. 754p.

ULRICH, A. \& HILLS, F.J. Principles and pratices of plant analysis. In: HARDY, G.W., ed. Soil testing and plant analysis. Madison, American Society of Agronomy. 1967. p.11-24. (SSSA Special Publications, 2). 
WALLACE, A. Nitrogen, phophorus, potassium interactions on Valencia orange yields. Journal of Plant Nutrition, New York, 13(3/4): 357-65, 1990.

WEIR, C.C. Nutrient element balance in citrus nutrition. Plant and Soil, Haren, 30(3): 405-14, 1969.

WEIR, R.G.; BEVINGTON, K.B.; DUNCAN, J.H.; CRADOCK, F.W. The effect of phosphorus on fruit quality, leaf analysis and yield of Valencia oranges. In: INTERNATIONAL CITRUS CONGRESS, Sidney, 1978. Proceedings. Sidney, International Society of Citriculture, 1978. p.292-5. 
APÊNDICE 
Tabela 11: Quadro da análise de variância para a regressão múltipla entre parâmetros do solo nas duas profundidades e a Produção Relativa, o coeficiente de determinação $\left(R^{2}\right)$ e o coeficiente de determinação ajustado $\left(\mathrm{R}_{\mathrm{a}}^{2}\right)$ para a equação.

\begin{tabular}{ccccc}
\hline $\begin{array}{c}\text { Causas da } \\
\text { Variação }\end{array}$ & GL & QM & F & Pr $>$ F \\
\hline Regressão & 17 & 649,555 & 40,42 & 0,0001 \\
Resíduo & 12 & 16,069 & \\
Total & 29 & & \\
\hline \multicolumn{5}{c}{$\mathrm{R}^{2}=0,983$} \\
\hline
\end{tabular}

Tabela 12: Quadro dos parâmetros da equação escolhida, para a regressão múltipla entre parâmetros do solo nas duas profundidades e a Produção Relativa.

\begin{tabular}{lccccc}
\hline \multicolumn{1}{c}{ Variável } & Estimativa & Erro padrão & SQ & $\mathbf{F}$ & Pr $>\mathbf{F}$ \\
\hline Interseção & $-10,505$ & 9,858 & 18,248 & 1,14 & 0,3076 \\
$\mathrm{P}_{0-20 \mathrm{~cm}}$ & 0,362 & 0,039 & 1387,442 & 86,34 & 0,0001 \\
$\mathrm{P}_{21-40 \mathrm{~cm}}$ & $-1,126$ & 0,170 & 707,737 & 44,04 & 0,0001 \\
$\mathrm{M}_{0} \mathrm{O}_{21-40 \mathrm{~cm}}$ & 2,625 & 0,200 & 2755,059 & 171,45 & 0,0001 \\
$\mathrm{~K}_{0-20 \mathrm{~cm}}$ & 6,707 & 2,002 & 180,337 & 11,22 & 0,0058 \\
$\mathrm{~K}_{21-40 \mathrm{~cm}}$ & $-37,621$ & 2,944 & 2623,368 & 163,26 & 0,0001 \\
$\mathrm{Ca}_{0-20 \mathrm{~cm}}$ & $-0,884$ & 0,150 & 558,289 & 34,74 & 0,0001 \\
$\mathrm{H}+\mathrm{Al}_{0-20 \mathrm{~cm}}$ & $-1,396$ & 0,146 & 1467,672 & 91,34 & 0,0001 \\
$\mathrm{Al}^{3+}{ }_{21-40 \mathrm{~cm}}$ & $-11,283$ & 1,494 & 916,261 & 57,02 & 0,0001 \\
$\mathrm{~T}_{21-40 \mathrm{~cm}}$ & 0,968 & 0,199 & 379,101 & 23,59 & 0,0004 \\
$\mathrm{~m}_{21-40 \mathrm{~cm}}$ & 4,798 & 0,618 & 968,471 & 60,27 & 0,0001 \\
$\mathrm{~B}_{21-40 \mathrm{~cm}}$ & 118,532 & 14,380 & 1091,787 & 67,94 & 0,0001 \\
$\mathrm{Cu}_{21-40 \mathrm{~cm}}$ & 18,884 & 1,671 & 2051,266 & 127,67 & 0,0001 \\
$\mathrm{Fe}_{21-40 \mathrm{~cm}}$ & 1,141 & 0,195 & 840,539 & 52,31 & 0,0001 \\
$\mathrm{Mn}_{0-20 \mathrm{~cm}}$ & 1,278 & 0,609 & 70,735 & 4,40 & 0,0577 \\
$\mathrm{Mn}_{21-40 \mathrm{~cm}}$ & $-2,752$ & 0,937 & 138,556 & 8,62 & 0,0125 \\
$\mathrm{Zn}_{21-40 \mathrm{~cm}}$ & 5,063 & 1,162 & 305,000 & 18,98 & 0,0009 \\
$\mathrm{Mg} / \mathrm{K}_{0-20 \mathrm{~cm}}$ & 0,614 & 0,387 & 40,437 & 2,52 & 0,1387 \\
\hline
\end{tabular}


Tabela 13: Quadro da análise de variância para a regressão múltipla entre os parâmetros do solo nas duas profundidades e massa média dos frutos, o coeficiente de determinação $\left(R^{2}\right)$ e o coeficiente de determinação ajustado $\left(\mathrm{R}_{\mathrm{a}}^{2}\right)$ para a equação.

\begin{tabular}{ccccc}
\hline $\begin{array}{c}\text { Causas da } \\
\text { Variação }\end{array}$ & GL & QM & F & Prob > F \\
\hline Regressão & 18 & 892,413 & 37,82 & 0,0001 \\
Resíduo & 11 & 23,596 & & \\
Total & 29 & & \\
\hline \multicolumn{5}{c}{$\mathrm{R}^{2}=0,984$} \\
\hline
\end{tabular}

Tabela 14: Quadro dos parâmetros da equação escolhida, para a regressão múltipla entre os parâmetros do solo nas duas profundidades e a massa média dos frutos.

\begin{tabular}{lccccc}
\hline \multicolumn{1}{c}{ Variável } & Estimativa & Erro padrão & $\mathbf{S Q}$ & $\mathbf{F}$ & $\mathbf{P r}>\mathbf{F}$ \\
\hline Interseção & 201,493 & 40,772 & 576,279 & 24,42 & 0,0004 \\
$\mathrm{P}_{0-20 \mathrm{~cm}}$ & $-0,165$ & 0,052 & 233,633 & 9,90 & 0,0093 \\
$\mathrm{P}_{21-40 \mathrm{~cm}}$ & 0,528 & 0,169 & 230,588 & 9,77 & 0,0096 \\
$\mathrm{pH}_{0-20 \mathrm{~cm}}$ & 59,509 & 4,990 & 3355,389 & 142,20 & 0,0001 \\
$\mathrm{pH}_{21-40 \mathrm{~cm}}$ & $-45,934$ & 9,348 & 569,707 & 24,14 & 0,0005 \\
$\mathrm{~K}_{0-20 \mathrm{~cm}}$ & 14,115 & 3,064 & 500,809 & 21,22 & 0,0008 \\
$\mathrm{~K}_{21-40 \mathrm{~cm}}$ & 18,044 & 7,544 & 134,971 & 5,72 & 0,0358 \\
$\mathrm{Ca}_{21-40 \mathrm{~cm}}$ & 0,797 & 0,629 & 37,889 & 1,61 & 0,2313 \\
$\mathrm{Al}^{3+}{ }_{21-40 \mathrm{~cm}}$ & $-4,901$ & 2,848 & 69,862 & 2,96 & 0,1133 \\
$\mathrm{~T}_{21-40 \mathrm{~cm}}$ & $-1,964$ & 0,527 & 327,821 & 13,89 & 0,0033 \\
$\mathrm{~m}_{0-20 \mathrm{~cm}}$ & 2,159 & 0,398 & 696,139 & 29,50 & 0,0002 \\
$\mathrm{~m}_{21-40 \mathrm{~cm}}$ & 3,232 & 1,064 & 217,881 & 9,23 & 0,0113 \\
$\mathrm{Cu}_{21-40 \mathrm{~cm}}$ & 15,863 & 1,610 & 2290,308 & 97,06 & 0,0001 \\
$\mathrm{Fe}_{0-20 \mathrm{~cm}}$ & $-0,844$ & 0,261 & 246,996 & 10,47 & 0,0079 \\
$\mathrm{Fe}_{21-40 \mathrm{~cm}}$ & 0,841 & 0,248 & 270,646 & 11,47 & 0,0061 \\
$\mathrm{Ca} / \mathrm{K}_{0-20 \mathrm{~cm}}$ & $-1,429$ & 0,523 & 176,458 & 7,48 & 0,0194 \\
$\mathrm{Ca} / \mathrm{K}_{21-40 \mathrm{~cm}}$ & 1,594 & 0,787 & 96,844 & 4,10 & 0,0677 \\
$\mathrm{Mg}_{\mathrm{K}} \mathrm{K}_{21-40 \mathrm{~cm}}$ & $-9,430$ & 1,117 & 1681,693 & 71,27 & 0,0001 \\
$\mathrm{~K}_{\mathrm{T} 21-40 \mathrm{~cm}}$ & $-36,282$ & 4,751 & 1376,234 & 58,32 & 0,0001 \\
\hline
\end{tabular}


Tabela 15: Quadro da análise de variância, para a regressão múltipla entre parâmetros do solo nas duas profundidades e a espessura da casca, o coeficiente de determinação $\left(R^{2}\right)$ e $o$ coeficiente de determinação ajustado $\left(\mathrm{R}_{\mathrm{a}}^{2}\right)$ para a equação.

\begin{tabular}{ccccc}
\hline $\begin{array}{c}\text { Causas da } \\
\text { Variação }\end{array}$ & GL & QM & F & Prob > F \\
\hline Regressão & 17 & 1409,451 & 8,72 & 0,0002 \\
Resíduo & 12 & 161,569 & & \\
Total & 29 & & \\
\hline \multicolumn{5}{c}{$\mathrm{R}^{2}=0,925$} \\
\hline
\end{tabular}

Tabela 16: Quadro dos parâmetros da equação escolhida, para a regressão múltipla entre os parâmetros do solo nas duas profundidades e a espessura da casca.

\begin{tabular}{lccccc}
\hline \multicolumn{1}{c}{ Variável } & Estimativa & Erro padrão & $\mathbf{S Q}$ & $\mathbf{F}$ & $\mathbf{P r}>\mathbf{F}$ \\
\hline Interseção & $-24,847$ & 75,388 & 17,551 & 0,11 & 0,7474 \\
argila $\mathrm{a}_{0-20 \mathrm{~cm}}$ & 0,061 & 0,043 & 331,748 & 2,05 & 0,1774 \\
${\mathrm{M} \cdot \mathrm{O}_{21-40 \mathrm{~cm}}}$ & 0,962 & 0,683 & 320,641 & 1,98 & 0,1843 \\
$\mathrm{pH}_{0-20 \mathrm{~cm}}$ & 116,220 & 19,547 & 5711,829 & 35,35 & 0,0001 \\
$\mathrm{~K}_{0-20 \mathrm{~cm}}$ & 9,005 & 7,880 & 210,993 & 1,31 & 0,2754 \\
$\mathrm{~K}_{21-40 \mathrm{~cm}}$ & $-30,148$ & 12,161 & 993,035 & 6,15 & 0,0290 \\
$\mathrm{H}+\mathrm{Al}_{0-20 \mathrm{~cm}}$ & $-1,910$ & 0,782 & 963,885 & 5,97 & 0,0310 \\
$\mathrm{Al}^{3+}{ }_{21-40 \mathrm{~cm}}$ & 7,700 & 2,210 & 1960,837 & 12,14 & 0,0045 \\
$\mathrm{~S}_{0-20 \mathrm{~cm}}$ & 2,300 & 0,830 & 1240,027 & 7,67 & 0,0170 \\
$\mathrm{~T}_{21-40 \mathrm{~cm}}$ & $-0,756$ & 0,386 & 620,627 & 3,84 & 0,0736 \\
$\mathrm{~V}_{0-20 \mathrm{~cm}}$ & $-5,039$ & 1,305 & 2409,740 & 14,91 & 0,0023 \\
$\mathrm{~B}_{0-20 \mathrm{~cm}}$ & 77,870 & 27,278 & 1316,683 & 8,15 & 0,0145 \\
$\mathrm{Fe}_{0-20 \mathrm{~cm}}$ & $-0,494$ & 0,544 & 132,894 & 0,82 & 0,3823 \\
$\mathrm{Fe}_{21-40 \mathrm{~cm}}$ & 0,655 & 0,661 & 158,302 & 0,98 & 0,3418 \\
$\mathrm{Zn}_{0-20 \mathrm{~cm}}$ & 5,097 & 3,119 & 431,442 & 2,67 & 0,1282 \\
$\mathrm{Ca} / \mathrm{K}_{0-20 \mathrm{~cm}}$ & $-4,458$ & 1,195 & 2249,341 & 13,92 & 0,0029 \\
$\mathrm{Ca} / \mathrm{K}_{21-40 \mathrm{~cm}}$ & 1,808 & 1,026 & 501,628 & 3,10 & 0,1035 \\
$\mathrm{Mg}_{\mathrm{T}} 0-20 \mathrm{~cm}$ & 1,405 & 0,441 & 1637,922 & 10,14 & 0,0079 \\
\hline
\end{tabular}


Tabela 17: Quadro da análise de variância, para a regressão múltipla entre os parâmetros do solo nas duas profundidades e a porcentagem de suco, o coeficiente de determinação $\left(R^{2}\right)$ e o coeficiente de determinação ajustado $\left(\mathrm{R}_{\mathrm{a}}^{2}\right)$ para a equação.

\begin{tabular}{ccccc}
\hline $\begin{array}{c}\text { Causas da } \\
\text { Variação }\end{array}$ & GL & QM & F & Prob > F \\
\hline Regressão & 18 & 5,318 & 25,47 & 0,0001 \\
Resíduo & 11 & 0,209 & & \\
Total & 29 & & & \\
\hline \multicolumn{5}{c}{$\mathrm{R}^{2}=0,977$} \\
\hline
\end{tabular}

Tabela 18: Quadro dos parâmetros da equação escolhida, para a regressão múltipla entre os parâmetros do solo nas duas profundidade e a porcentagem de suco.

\begin{tabular}{lccccc}
\hline \multicolumn{1}{c}{ Variável } & Estimativa & Erro padrão & $\mathbf{S Q}$ & $\mathbf{F}$ & $\mathbf{P r}>\mathbf{F}$ \\
\hline Interseção & 37,432 & 3,610 & 22,445 & 107,51 & 0,0001 \\
$\mathrm{P}_{0-20 \mathrm{~cm}}$ & $-0,012$ & 0,005 & 1,033 & 4,95 & 0,0480 \\
$\mathrm{P}_{21-40 \mathrm{~cm}}$ & $-0,166$ & 0,023 & 10,493 & 50,26 & 0,0001 \\
$\mathrm{M} .0_{0-20 \mathrm{~cm}}$ & 0,115 & 0,033 & 2,591 & 12,41 & 0,0048 \\
$\mathrm{M} .0 \cdot 21-40 \mathrm{~cm}$ & $-0,415$ & 0,045 & 17,774 & 85,14 & 0,0001 \\
$\mathrm{pH}_{21-40 \mathrm{~cm}}$ & 2,560 & 0,803 & 2,124 & 10,17 & 0,0086 \\
$\mathrm{~K}_{0-20 \mathrm{~cm}}$ & $-2,948$ & 0,405 & 11,080 & 53,07 & 0,0001 \\
$\mathrm{Ca}_{21-40 \mathrm{~cm}}$ & 0,402 & 0,056 & 10,909 & 52,25 & 0,0001 \\
$\mathrm{Al}^{3+}{ }_{21-40 \mathrm{~cm}}$ & 0,926 & 0,076 & 30,937 & 148,18 & 0,0001 \\
$\mathrm{~S}_{0-20 \mathrm{~cm}}$ & 0,053 & 0,021 & 1,388 & 6,65 & 0,0257 \\
$\mathrm{~T}_{0-20 \mathrm{~cm}}$ & 0,174 & 0,024 & 10,670 & 51,11 & 0,0001 \\
$\mathrm{~B}_{21-40 \mathrm{~cm}}$ & 3,192 & 1,619 & 0,812 & 3,89 & 0,0742 \\
$\mathrm{Cu}_{0-20 \mathrm{~cm}}$ & $-0,504$ & 0,110 & 4,370 & 20,93 & 0,0008 \\
$\mathrm{Fe}_{21-40 \mathrm{~cm}}$ & $-0,204$ & 0,026 & 13,215 & 63,30 & 0,0001 \\
$\mathrm{Ca} \mathrm{K}_{0-20 \mathrm{~cm}}$ & $-0,445$ & 0,041 & 24,719 & 118,40 & 0,0001 \\
$\mathrm{Ca} \mathrm{Mg} \mathrm{g}_{21-40 \mathrm{~cm}}$ & 0,692 & 0,205 & 2,375 & 11,37 & 0,0062 \\
$\mathrm{Ca}_{\mathrm{T} 21-40 \mathrm{~cm}}$ & $-0,173$ & 0,044 & 3,177 & 15,22 & 0,0025 \\
$\mathrm{Mg}_{\mathrm{T} 21-40 \mathrm{~cm}}$ & 0,563 & 0,091 & 7,934 & 38,00 & 0,0001 \\
$\mathrm{~K}_{\mathrm{T} 0-20 \mathrm{~cm}}$ & 0,487 & 0,164 & 1,847 & 8,85 & 0,0126 \\
\hline
\end{tabular}


Tabela 19: Quadro da análise de variância, para a regressão múltipla entre os parâmetros do solo nas duas profundidades e a porcentagem de sólidos solúveis (Brix) do suco, o coeficiente de determinação $\left(R^{2}\right)$ e o coeficiente de determinação ajustado $\left(R^{2}{ }_{a}\right)$ para a equação.

\begin{tabular}{ccccc}
\hline $\begin{array}{c}\text { Causas da } \\
\text { Variação }\end{array}$ & GL & QM & F & Prob $>$ F \\
\hline Regressão & 17 & 1,452 & 11,57 & 0,0001 \\
Resíduo & 12 & 0,125 & & \\
Total & 29 & & & \\
\hline \multicolumn{5}{c}{$\mathrm{R}^{2}=\mathbf{0 , 9 4 3}$} \\
\hline
\end{tabular}

Tabela 20: Quadro dos parâmetros da equação escolhida, para a regressão múltipla entre os parâmetros do solo nas duas profundidades e a porcentagem de sólidos solúveis (Brix).

\begin{tabular}{lccccc}
\hline \multicolumn{1}{c}{ Variável } & Estimativa & Erro padrão & $\mathbf{S Q}$ & $\mathbf{F}$ & $\mathbf{P r}>\mathbf{F}$ \\
\hline Interseção & 10,423 & 1,527 & 8,403 & 46,57 & 0,0001 \\
$\mathrm{P}_{21-40 \mathrm{~cm}}$ & $-0,025$ & 0,016 & 2,271 & 2,39 & 0,1482 \\
$\mathrm{pH}_{0-20 \mathrm{~cm}}$ & $-0,401$ & 0,263 & 3,074 & 2,33 & 0,1524 \\
$\mathrm{~K}_{21-40 \mathrm{~cm}}$ & 1,954 & 0,433 & 1,016 & 20,36 & 0,0007 \\
$\mathrm{Mg}_{21-40 \mathrm{~cm}}$ & $-0,335$ & 0,139 & 2,918 & 5,80 & 0,0330 \\
$\mathrm{~V}_{21-40 \mathrm{~cm}}$ & 0,338 & 0,081 & 3,346 & 17,52 & 0,0013 \\
$\mathrm{~B}_{0-20 \mathrm{~cm}}$ & $-2,677$ & 0,790 & 1,556 & 11,47 & 0,0054 \\
$\mathrm{Cu}_{0-20 \mathrm{~cm}}$ & $-0,182$ & 0,157 & 1,901 & 1,35 & 0,2677 \\
$\mathrm{Cu}_{21-40 \mathrm{~cm}}$ & $-1,030$ & 0,203 & 2,270 & 25,87 & 0,0003 \\
$\mathrm{Fe}_{0-20 \mathrm{~cm}}$ & 0,037 & 0,012 & 0,702 & 9,55 & 0,0093 \\
$\mathrm{Mn}_{0-20 \mathrm{~cm}}$ & $-0,157$ & 0,052 & 3,612 & 9,09 & 0,0108 \\
$\mathrm{Mn}_{21-40 \mathrm{~cm}}$ & 0,401 & 0,080 & 2,007 & 25,04 & 0,0003 \\
$\mathrm{Zn}_{21-40 \mathrm{~cm}}$ & $-0,241$ & 0,114 & 1,680 & 4,45 & 0,0566 \\
$\mathrm{Ca} / \mathrm{K}_{21-40 \mathrm{~cm}}$ & 0,306 & 0,065 & 2,582 & 22,27 & 0,0005 \\
${\mathrm{Mg} / \mathrm{K}_{21-40 \mathrm{~cm}}}^{\mathrm{Ca} / \mathrm{Mg}_{0-20 \mathrm{~cm}}}$ & $-0,305$ & 0,098 & 1,234 & 9,65 & 0,0091 \\
$\mathrm{Ca}_{\mathrm{T} 21-40 \mathrm{~cm}}$ & 0,444 & 0,094 & 0,070 & 22,06 & 0,0005 \\
$\mathrm{~K}_{\mathrm{T} 0-20 \mathrm{~cm}}$ & $-0,423$ & 0,107 & 3,520 & 15,79 & 0,0018 \\
\hline & $-0,207$ & 0,049 & 6,189 & 17,90 & 0,0012 \\
\hline
\end{tabular}


Tabela 21: Quadro da análise de variância, para a regressão múltipla entre os parâmetros do solo nas duas profundidades e a acidez total do suco, o coeficiente de determinação $\left(R^{2}\right)$ e o coeficiente de determinação ajustado $\left(\mathrm{R}_{\mathrm{a}}^{2}\right)$ para a equação.

\begin{tabular}{ccccc}
\hline $\begin{array}{c}\text { Causas da } \\
\text { Variação }\end{array}$ & GL & QM & F & Prob $>$ F \\
\hline Regressão & 18 & 0,0804 & 30,42 & 0,0001 \\
Resíduo & 11 & 0,0026 & \\
Total & 29 & & \\
\hline & $\mathrm{R}^{2}=0,971$ & \multicolumn{2}{c}{$\mathrm{R}_{\mathrm{a}}^{2}=0,948$} \\
\hline
\end{tabular}

Tabela 22: Quadro dos parâmetros da equação escolhida, para a regressão múltipla entre os parâmetros do solo nas duas profundidades e a acidez total do suco.

\begin{tabular}{lccccc}
\hline \multicolumn{1}{c}{ Variável } & Estimativa & Erro padrão & SQ & F & Pr $>\mathbf{F}$ \\
\hline Interseção & $-0,625$ & 0,245 & 0,017 & 6,54 & 0,0266 \\
$\mathrm{P}_{21-40 \mathrm{~cm}}$ & $-0,006$ & 0,002 & 0,028 & 10,43 & 0,0080 \\
$\mathrm{M} .0 .0-20 \mathrm{~cm}$ & 0,012 & 0,003 & 0,053 & 19,95 & 0,0010 \\
$\mathrm{~K}_{21-40 \mathrm{~cm}}$ & $-1,332$ & 0,123 & 0,312 & 117,89 & 0,0001 \\
$\mathrm{Mg}_{21-40 \mathrm{~cm}}$ & 0,254 & 0,026 & 0,262 & 99,03 & 0,0001 \\
$\mathrm{~S}_{0-20 \mathrm{~cm}}$ & $-0,027$ & 0,003 & 0,239 & 90,54 & 0,0001 \\
$\mathrm{~T}_{21-40 \mathrm{~cm}}$ & 0,024 & 0,003 & 0,189 & 71,32 & 0,0001 \\
$\mathrm{~V}_{0-20 \mathrm{~cm}}$ & 0,020 & 0,003 & 0,095 & 35,84 & 0,0001 \\
$\mathrm{~V}_{21-40 \mathrm{~cm}}$ & $-0,092$ & 0,014 & 0,118 & 44,64 & 0,0001 \\
$\mathrm{~m}_{0-20 \mathrm{~cm}}$ & $-0,027$ & 0,003 & 0,188 & 71,05 & 0,0001 \\
$\mathrm{~m}_{21-40 \mathrm{~cm}}$ & 0,015 & 0,004 & 0,031 & 11,82 & 0,0055 \\
$\mathrm{~B}_{0-20 \mathrm{~cm}}$ & 0,408 & 0,105 & 0,070 & 15,19 & 0,0025 \\
$\mathrm{Cu}_{21-40 \mathrm{~cm}}$ & $-0,222$ & 0,023 & 0,249 & 94,26 & 0,0001 \\
$\mathrm{Mn}_{0-20 \mathrm{~cm}}$ & $-0,024$ & 0,008 & 0,022 & 8,39 & 0,1450 \\
$\mathrm{Mn}_{21-40 \mathrm{~cm}}$ & 0,044 & 0,013 & 0,032 & 12,27 & 0,0049 \\
$\mathrm{Zn}_{0-20 \mathrm{~cm}}$ & 0,140 & 0,018 & 0,154 & 58,19 & 0,0001 \\
$\mathrm{Ca}_{\mathrm{T} 21-40 \mathrm{~cm}}$ & 0,089 & 0,014 & 0,108 & 40,67 & 0,0001 \\
$\mathrm{~K}_{\mathrm{T} 0-20 \mathrm{~cm}}$ & $-0,018$ & 0,008 & 0,013 & 4,88 & 0,0493 \\
$\mathrm{~K}_{\mathrm{T} 21-40 \mathrm{~cm}}$ & 0,943 & 0,075 & 0,423 & 159,93 & 0,0001 \\
\hline & & & & & \\
\hline
\end{tabular}


Tabela 23: Quadro da análise de variância, para a regressão múltipla entre os parâmetros do solo nas duas profundidades e a relação sólidos solúveis:acidez total, o coeficiente de determinação $\left(R^{2}\right)$ e o coeficiente de determinação ajustado $\left(R^{2}\right)$ para a equação.

\begin{tabular}{ccccc}
\hline $\begin{array}{c}\text { Causas da } \\
\text { Variação }\end{array}$ & GL & QM & F & Prob > F \\
\hline Regressão & 17 & 2,181 & 12,23 & 0,0001 \\
Resíduo & 12 & 0,178 & \\
Total & 29 & & \\
\hline & $\mathrm{R}^{2}=0,945$ & \multicolumn{3}{c}{$\mathrm{R}_{\mathrm{a}}^{2}=0,867$} \\
\hline
\end{tabular}

Tabela 24: Quadro dos parâmetros da equação escolhida, para a regressão múltipla entre os parâmetros do solo nas duas profundidades e a relação sólidos solúveis:acidez total.

\begin{tabular}{|c|c|c|c|c|c|}
\hline Variável & Estimativa & Erro padrão & SQ & $\mathbf{F}$ & $\operatorname{Pr}>\mathbf{F}$ \\
\hline Interseção & 2,473 & 2,368 & 0,194 & 1,09 & 0,3170 \\
\hline M.O.0-20cm & 0,097 & 0,024 & 2,941 & 16,50 & 0,0016 \\
\hline M.O. $21-40 \mathrm{~cm}$ & $-0,143$ & 0,032 & 3,481 & 19,53 & 0,0008 \\
\hline $\mathrm{pH}_{0-20 \mathrm{~cm}}$ & 2,791 & 0,690 & 2,916 & 16,53 & 0,0016 \\
\hline $\mathrm{K}_{21-40 \mathrm{~cm}}$ & 1,603 & 0,442 & 2,347 & 13,17 & 0,0035 \\
\hline $\mathrm{Mg}_{21-40 \mathrm{~cm}}$ & $-0,493$ & 0,112 & 3,450 & 19,35 & 0,0009 \\
\hline $\mathrm{S}_{0-20 \mathrm{~cm}}$ & 0,125 & 0,023 & 5,308 & 29,78 & 0,0001 \\
\hline $\mathrm{V}_{0-20 \mathrm{~cm}}$ & $-0,227$ & 0,036 & 6,984 & 39,17 & 0,0001 \\
\hline $\mathrm{m}_{0-20 \mathrm{~cm}}$ & 0,104 & 0,026 & 2,903 & 16,28 & 0,0017 \\
\hline $\mathrm{m}_{21-40 \mathrm{~cm}}$ & $-0,073$ & 0,027 & 1,333 & 7,48 & 0,0181 \\
\hline $\mathrm{B}_{0-20 \mathrm{~cm}}$ & $-2,357$ & 0,960 & 1,076 & 6,03 & 0,0302 \\
\hline $\mathrm{Cu}_{0-20 \mathrm{~cm}}$ & $-0,620$ & 0,144 & 3,291 & 18,46 & 0,0010 \\
\hline $\mathrm{Cu}_{21-40 \mathrm{~cm}}$ & 0,458 & 0,197 & 0,964 & 5,41 & 0,0384 \\
\hline $\mathrm{Fe}_{0-20 \mathrm{~cm}}$ & 0,029 & 0,016 & 0,581 & 3,26 & 0,0962 \\
\hline $\mathrm{Zn}_{21-40 \mathrm{~cm}}$ & $-0,288$ & 0,103 & 1,398 & 7,84 & 0,0160 \\
\hline $\mathrm{Ca} / \mathrm{K}_{0-20 \mathrm{~cm}}$ & $-0,061$ & 0,024 & 1,158 & 6,49 & 0,0256 \\
\hline $\mathrm{Mg} / \mathrm{K}_{21-40 \mathrm{~cm}}$ & 0,396 & 0,073 & 5,194 & 29,14 & 0,0002 \\
\hline $\mathrm{CaT}_{0-20 \mathrm{~cm}}$ & 0,008 & 0,004 & 0,778 & 4,37 & 0,0586 \\
\hline
\end{tabular}


Tabela 25: Quadro da análise de variância, para a regressão múltipla entre os parâmetros da análise foliar e a Produção Relativa (PR), o coeficiente de determinação $\left(R^{2}\right)$ e o coeficiente de determinação ajustado $\left(\mathrm{R}_{\mathrm{a}}^{2}\right)$ para a equação.

\begin{tabular}{ccccc}
\hline $\begin{array}{c}\text { Causas da } \\
\text { Variação }\end{array}$ & GL & QM & F & Prob > F \\
\hline Regressão & 18 & 589,885 & 10,51 & 0,0002 \\
Resíduo & 11 & 56,121 & \\
Total & 29 & & \\
\hline \multicolumn{2}{c}{$\mathrm{R}^{2}=0,945$} & \multicolumn{2}{c}{$\mathrm{R}_{\mathrm{a}}^{2}=0,855$} \\
\hline
\end{tabular}

Tabela 26: Quadro dos parâmetros da equação escolhida, para a regressão múltipla entre os parâmetros da análise foliar e a Produção Relativa (PR).

\begin{tabular}{|c|c|c|c|c|c|}
\hline Variável & Estimativa & Erro padrão & SQ & $\mathbf{F}$ & $\operatorname{Pr}>\mathbf{F}$ \\
\hline Interseção & $-561,140$ & 97,951 & 1841,833 & 32,82 & 0,0001 \\
\hline$S$ & $-44,499$ & 12,018 & 769,371 & 13,71 & 0,0035 \\
\hline $\mathrm{Cu}$ & 13,182 & 2,379 & 1722,302 & 30,69 & 0,0002 \\
\hline $\mathrm{Mg}^{2}$ & 1,822 & 0,657 & 431,517 & 7,69 & 0,0181 \\
\hline $\mathrm{B}^{2}$ & 0,018 & 0,002 & 3390,873 & 60,42 & 0,0001 \\
\hline $\mathrm{Cu}^{2}$ & $-0,070$ & 0,018 & 872,781 & 15,55 & 0,0023 \\
\hline $\mathrm{Zn}^{2}$ & $-0,007$ & 0,001 & 2146,921 & 38,25 & 0,0001 \\
\hline $\mathrm{N} / \mathrm{S}$ & $-10,977$ & 1,759 & 2186,548 & 38,96 & 0,0001 \\
\hline $\mathrm{N} / \mathrm{Cu}$ & 685,094 & 68,174 & 5667,476 & 100,99 & 0,0001 \\
\hline N/Mn & $-38,886$ & 7,655 & 1448,340 & 25,81 & 0,0004 \\
\hline $\mathrm{P} / \mathrm{Mg}$ & 132,256 & 19,398 & 2608,954 & 46,49 & 0,0001 \\
\hline $\mathrm{P} / \mathrm{Zn}$ & $-2566,835$ & 362,804 & 2809,176 & 50,06 & 0,0001 \\
\hline $\mathrm{K} / \mathrm{Fe}$ & 1009,360 & 144,823 & 2726,123 & 48,58 & 0,0001 \\
\hline $\mathrm{Ca} / \mathrm{Mn}$ & 24,918 & 4,787 & 1520,675 & 27,10 & 0,0003 \\
\hline $\mathrm{Mg} / \mathrm{B}$ & 430,281 & 219,335 & 215,982 & 3,85 & 0,0756 \\
\hline $\mathrm{Mg} / \mathrm{Mn}$ & $-191,438$ & 28,523 & 2528,004 & 45,05 & 0,0001 \\
\hline $\mathrm{S} / \mathrm{Mn}$ & 218,279 & 52,869 & 956,638 & 17,05 & 0,0017 \\
\hline $\mathrm{B} / \mathrm{Cu}$ & $-55,955$ & 10,878 & 1484,811 & 26,46 & 0,0003 \\
\hline $\mathrm{Mn} / \mathrm{Zn}$ & 26,129 & 7,413 & 697,315 & 12,43 & 0,0048 \\
\hline
\end{tabular}


Tabela 27: Quadro da análise de variância, para a regressão múltipla entre os parâmetros da análise foliar e a massa média dos frutos, o coeficiente de determinação $\left(\mathrm{R}^{2}\right)$ e o coeficiente de determinação ajustado $\left(\mathrm{R}_{\mathrm{a}}^{2}\right)$ para a equação.

\begin{tabular}{ccccc}
\hline $\begin{array}{c}\text { Causas da } \\
\text { Variação }\end{array}$ & GL & QM & F & Prob > F \\
\hline Regressão & 17 & 913,929 & 13,95 & 0,0001 \\
$\begin{array}{c}\text { Resíduo } \\
\text { Total }\end{array}$ & 12 & 65,517 & & \\
\hline \multicolumn{5}{c}{$\mathrm{R}^{2}=0,952$} \\
\hline
\end{tabular}

Tabela 28: Quadro dos parâmetros da equação escolhida, para a regressão múltipla entre os parâmetros da análise foliar e a massa média dos frutos.

\begin{tabular}{lccccc}
\hline \multicolumn{1}{c}{ Variável } & Estimativa & Erro padrão & SQ & F & Pr $>$ F \\
\hline Interseção & $-172,589$ & 43,948 & 1010,403 & 15,42 & 0,0020 \\
$\mathrm{~S}$ & $-57,122$ & 17,372 & 708,374 & 10,81 & 0,0065 \\
$\mathrm{Mg}^{2}$ & 5,676 & 1,516 & 918,929 & 14,03 & 0,0028 \\
$\mathrm{~N} / \mathrm{B}$ & 179,565 & 44,650 & 1059,672 & 16,17 & 0,0017 \\
$\mathrm{P} / \mathrm{Fe}$ & $-12085,219$ & 3210,349 & 928,454 & 14,17 & 0,0027 \\
$\mathrm{~K} / \mathrm{Ca}$ & $-139,087$ & 26,857 & 1757,134 & 26,82 & 0,0002 \\
$\mathrm{Ca} / \mathrm{Mg}$ & 7,281 & 0,904 & 4249,149 & 64,86 & 0,0001 \\
$\mathrm{Ca} / \mathrm{Cu}$ & 164,410 & 36,774 & 1309,598 & 19,99 & 0,0008 \\
$\mathrm{Ca} / \mathrm{Zn}$ & $-607,510$ & 72,473 & 4603,721 & 7,27 & 0,0001 \\
$\mathrm{Mg} / \mathrm{Cu}$ & $-584,387$ & 327,732 & 208,314 & 3,18 & 0,0999 \\
$\mathrm{Mg} / \mathrm{Zn}$ & 1482,275 & 313,452 & 1465,110 & 22,36 & 0,0005 \\
$\mathrm{~S} / \mathrm{Cu}$ & 4490,226 & 767,252 & 2243,966 & 34,25 & 0,0001 \\
$\mathrm{~S} / \mathrm{Zn}$ & $-2074,896$ & 451,538 & 1383,436 & 21,12 & 0,0006 \\
$\mathrm{~B} / \mathrm{Fe}$ & 262,823 & 38,790 & 3007,725 & 45,91 & 0,0001 \\
$\mathrm{Cu} / \mathrm{Fe}$ & 131,578 & 113,076 & 88,721 & 1,35 & 0,2672 \\
$\mathrm{Cu} / \mathrm{Zn}$ & 325,512 & 39,421 & 4467,204 & 68,18 & 0,0001 \\
$\mathrm{Fe} / \mathrm{Mn}$ & $-1,330$ & 0,138 & 6090,014 & 92,95 & 0,0001 \\
$\mathrm{Fe} / \mathrm{Zn}$ & 17,805 & 6,250 & 531,660 & 8,11 & 0,0147 \\
\hline & & & & &
\end{tabular}


Tabela 29: Quadro da análise de variância, para a regressão múltipla entre os parâmetros da análise foliar e a espessura da casca, o coeficiente de determinação $\left(R^{2}\right)$ e o coeficiente de determinação ajustado $\left(R^{2}\right)$ para a equação.

\begin{tabular}{ccccc}
\hline $\begin{array}{c}\text { Causas da } \\
\text { Variação }\end{array}$ & GL & QM & F & Prob > F \\
\hline Regressão & 18 & 1419,905 & 45,78 & 0,0001 \\
Resíduo & 11 & 31,018 & \\
Total & 29 & & \\
\hline & $\mathrm{R}^{2}=0,987$ & \multicolumn{3}{c}{$\mathrm{R}_{\mathrm{a}}^{2}=0,966$} \\
\hline
\end{tabular}

Tabela 30: Quadro dos parâmetros da equação escolhida, para a regressão múltipla entre os parâmetros da análise foliar e a espessura da casca.

\begin{tabular}{|c|c|c|c|c|c|}
\hline Variável & Estimativa & Erro padrão & SQ & $\mathbf{F}$ & $\operatorname{Pr}>\mathbf{F}$ \\
\hline Interseção & 153,967 & 26,214 & 1070,028 & 34,50 & 0,0001 \\
\hline $\mathrm{N}$ & 6,506 & 1,041 & 1211,302 & 39,05 & 0,0001 \\
\hline $\mathrm{K}$ & $-3,225$ & 0,563 & 1017,913 & 32,82 & 0,0001 \\
\hline $\mathrm{Zn}^{2}$ & $-0,002$ & 0,008 & 202,742 & 6,54 & 0,0267 \\
\hline $\mathrm{N} / \mathrm{P}$ & $-12,712$ & 1,926 & 1351,008 & 43,56 & 0,0001 \\
\hline $\mathrm{N} / \mathrm{Ca}$ & 313,106 & 58,171 & 898,627 & 28,97 & 0,0002 \\
\hline $\mathrm{N} / \mathrm{Mg}$ & $-6,930$ & 1,769 & 476,137 & 15,35 & 0,0024 \\
\hline $\mathrm{N} / \mathrm{B}$ & $-49,367$ & 41,087 & 44,780 & 1,44 & 0,2548 \\
\hline $\mathrm{P} / \mathrm{Cu}$ & $-5326,806$ & 1302,564 & 518,741 & 16,72 & 0,0018 \\
\hline $\mathrm{P} / \mathrm{Mn}$ & $-289,725$ & 67,946 & 563,974 & 18,18 & 0,0013 \\
\hline $\mathrm{Ca} / \mathrm{Mg}$ & 9,721 & 1,093 & 2453,340 & 79,09 & 0,0001 \\
\hline $\mathrm{Ca} / \mathrm{Cu}$ & 312,841 & 48,900 & 1269,517 & 40,93 & 0,0001 \\
\hline $\mathrm{Ca} / \mathrm{Fe}$ & $-468,577$ & 99,633 & 686,073 & 22,12 & 0,0006 \\
\hline $\mathrm{Ca} / \mathrm{Zn}$ & $-160,422$ & 16,822 & 2820,780 & 90,94 & 0,0001 \\
\hline $\mathrm{Mg} / \mathrm{S}$ & $-12,288$ & 3,445 & 394,693 & 12,72 & 0,0044 \\
\hline $\mathrm{Mg} / \mathrm{B}$ & 1277,629 & 214,997 & 1095,370 & 35,31 & 0,0001 \\
\hline $\mathrm{Mg} / \mathrm{Mn}$ & 62,131 & 22,469 & 237,177 & 7,65 & 0,0184 \\
\hline $\mathrm{B} / \mathrm{Zn}$ & 66,143 & 7,997 & 2121,756 & 68,40 & 0,0001 \\
\hline $\mathrm{Cu} / \mathrm{Fe}$ & 272,816 & 62,270 & 595,379 & 19,19 & 0,0011 \\
\hline
\end{tabular}


Tabela 31: Quadro da análise de variância, para a regressão múltipla entre os parâmetros da análise foliar e a porcentagem de suco, o coeficiente de determinação $\left(R^{2}\right)$ e o coeficiente de determinação ajustado $\left(R^{2}\right)$ para a equação.

\begin{tabular}{ccccc}
\hline $\begin{array}{c}\text { Causas da } \\
\text { Variação }\end{array}$ & GL & QM & F & Prob $>$ F \\
\hline Regressão & 16 & 6,053 & 66,95 & 0,0001 \\
Resíduo & 13 & 0,090 & & \\
Total & 29 & & & \\
\hline \multicolumn{2}{c}{$\mathrm{R}^{2}=0,988$} & $\mathrm{R}_{\mathrm{a}}^{2}=0,973$ & \\
\hline
\end{tabular}

Tabela 32: Quadro dos parâmetros da equação escolhida, para a regressão múltipla entre os parâmetros da análise foliar e a porcentagem de suco.

\begin{tabular}{lccccc}
\hline \multicolumn{1}{c}{ Variável } & Estimativa & Erro padrão & SQ & F & Pr $>$ F \\
\hline Interseção & 52,377 & 1,410 & 124,760 & 1379,97 & 0,0001 \\
$\mathrm{Cu}$ & 0,475 & 0,042 & 11,399 & 126,08 & 0,0001 \\
$\mathrm{~N}^{2}$ & 0,013 & 0,001 & 8,609 & 95,23 & 0,0001 \\
$\mathrm{Cu}^{2}$ & $-0,002$ & 0,0003 & 3,471 & 38,39 & 0,0001 \\
$\mathrm{Fe}^{2}$ & $-0,0002$ & 0,00001 & 34,294 & 379,33 & 0,0001 \\
$\mathrm{Zn}^{2}$ & 0,0004 & 0,00001 & 15,692 & 173,57 & 0,0001 \\
$\mathrm{~N} / \mathrm{P}$ & $-0,223$ & 0,052 & 1,560 & 18,36 & 0,0009 \\
$\mathrm{P} / \mathrm{S}$ & $-19,873$ & 1,445 & 17,095 & 189,09 & 0,0001 \\
$\mathrm{P} / \mathrm{Mn}$ & 9,951 & 3,150 & 0,866 & 9,58 & 0,0085 \\
$\mathrm{~K} / \mathrm{S}$ & 0,662 & 0,074 & 7,261 & 80,31 & 0,0001 \\
$\mathrm{~K} / \mathrm{B}$ & $-4,951$ & 1,519 & 0,961 & 10,62 & 0,0062 \\
$\mathrm{Ca} / \mathrm{Mg}$ & 0,297 & 0,024 & 13,606 & 150,49 & 0,0001 \\
$\mathrm{Mg} / \mathrm{S}$ & 3,356 & 0,241 & 17,474 & 193,28 & 0,0001 \\
$\mathrm{~B} / \mathrm{MN}$ & $-0,402$ & 0,295 & 16,785 & 185,66 & 0,0001 \\
$\mathrm{Cu} / \mathrm{Fe}$ & $-80,193$ & 3,909 & 38,057 & 420,95 & 0,0001 \\
$\mathrm{Cu} / \mathrm{Mn}$ & 1,131 & 0,094 & 13,140 & 145,34 & 0,0001 \\
$\mathrm{Mn} / \mathrm{Zn}$ & 5,908 & 0,314 & 32,059 & 354,61 & 0,0001 \\
\hline
\end{tabular}


Tabela 33: Quadro da análise de variância, para a regressão múltipla entre os parâmetros da análise foliar e os sólidos solúveis totais do suco (Brix), o coeficiente de determinação $\left(\mathrm{R}^{2}\right)$ e o coeficiente de determinação ajustado $\left(R^{2}\right)$ para a equação.

\begin{tabular}{ccccc}
\hline $\begin{array}{c}\text { Causas da } \\
\text { Variação }\end{array}$ & GL & QM & F & Prob > F \\
\hline Regressão & 17 & 1,509 & 33,27 & 0,0001 \\
Resíduo & 12 & 0,045 & & \\
Total & 29 & & & \\
\hline \multicolumn{5}{c}{$\mathrm{R}^{2}=0,979$} \\
\hline
\end{tabular}

Tabela 34: Quadro dos parâmetros da equação escolhida, para a regressão múltipla entre os parâmetros da análise foliar e os sólidos solúveis totais do suco (Brix).

\begin{tabular}{lccccc}
\hline \multicolumn{1}{c}{ Variável } & Estimativa & Erro padrão & SQ & $\mathbf{F}$ & $\mathbf{P r}>\mathbf{F}$ \\
\hline Interseção & 6,508 & 1,692 & 0,670 & 14,79 & 0,0023 \\
$\mathrm{Mg}$ & $-1,586$ & 0,223 & 2,300 & 50,74 & 0,0001 \\
$\mathrm{~S}$ & 1,874 & 0,569 & 0,491 & 10,83 & 0,0065 \\
$\mathrm{Fe}^{2}$ & -00001 & 0,000 & 0,202 & 4,47 & 0,0562 \\
$\mathrm{~N} / \mathrm{K}$ & 2,108 & 0,232 & 3,727 & 82,19 & 0,0001 \\
$\mathrm{P} / \mathrm{K}$ & $-23,852$ & 5,401 & 0,884 & 19,50 & 0,0008 \\
$\mathrm{P} / \mathrm{Mg}$ & $-15,652$ & 1,627 & 4,198 & 92,59 & 0,0001 \\
$\mathrm{P} / \mathrm{S}$ & 19,164 & 1,937 & 4,440 & 97,93 & 0,0001 \\
$\mathrm{P} / \mathrm{Zn}$ & $-92,185$ & 19,879 & 0,975 & 21,51 & 0,0006 \\
$\mathrm{~K} / \mathrm{Mg}$ & 1,436 & 0,144 & 4,482 & 98,85 & 0,0001 \\
$\mathrm{~K} / \mathrm{S}$ & $-1,668$ & 0,168 & 4,490 & 99,01 & 0,0001 \\
$\mathrm{~K} / \mathrm{Fe}$ & 75,325 & 13,008 & 1,520 & 33,53 & 0,0001 \\
$\mathrm{~K} / \mathrm{Mn}$ & 0,463 & 0,641 & 2,366 & 52,19 & 0,0001 \\
$\mathrm{Mg} / \mathrm{Cu}$ & 16,388 & 4,629 & 0,568 & 12,53 & 0,0041 \\
$\mathrm{~S} / \mathrm{B}$ & 106,032 & 11,378 & 3,934 & 86,84 & 0,0001 \\
$\mathrm{~S} / \mathrm{Fe}$ & $-539,537$ & 67,650 & 2,884 & 63,61 & 0,0001 \\
$\mathrm{~B} / \mathrm{Zn}$ & 1,882 & 0,282 & 2,012 & 44,37 & 0,0001 \\
$\mathrm{Cu} / \mathrm{Zn}$ & $-1,237$ & 0,477 & 0,305 & 6,72 & 0,0236 \\
\hline
\end{tabular}


Tabela 35: Quadro da análise de variância, para a regressão múltipla entre os parâmetros da análise foliar e a acidez total do suco, o coeficiente de determinação $\left(R^{2}\right)$ e o coeficiente de determinação ajustado $\left(\mathrm{R}_{\mathrm{a}}^{2}\right)$ para a equação.

\begin{tabular}{ccccc}
\hline $\begin{array}{c}\text { Causas da } \\
\text { Variação }\end{array}$ & GL & QM & F & Prob $>$ F \\
\hline Regressão & 19 & 0,0129 & 10,68 & 0,0003 \\
Resíduo & 10 & 0,0012 & & \\
Total & 29 & & & \\
\hline \multicolumn{5}{c}{$\mathrm{R}^{2}=0,953$} \\
\hline
\end{tabular}

Tabela 36: Quadro dos parâmetros da equação escolhida, para a regressão múltipla entre os parâmetros da análise foliar e a acidez total do suco.

\begin{tabular}{lccccc}
\hline \multicolumn{1}{c}{ Variável } & Estimativa & Erro padrão & SQ & F & Pr $>$ F \\
\hline Interseção & 0,765 & 0,437 & 0,004 & 3,06 & 0,1110 \\
$\mathrm{~S}$ & 0,177 & 0,065 & 0,009 & 7,34 & 0,0219 \\
$\mathrm{~B}$ & 0,018 & 0,007 & 0,008 & 6,59 & 0,0280 \\
$\mathrm{Zn}$ & $-0,005$ & 0,000 & 0,044 & 36,38 & 0,0001 \\
$\mathrm{~B} 2$ & $-0,00001$ & 0,000 & 0,005 & 4,2 & 0,0671 \\
$\mathrm{Cu}^{2}$ & 0,0001 & 0,000 & 0,043 & 35,54 & 0,0001 \\
$\mathrm{~N} / \mathrm{Mg}$ & $-0,046$ & 0,005 & 0,104 & 85,99 & 0,0001 \\
$\mathrm{~N} / \mathrm{S}$ & 0,077 & 0,012 & 0,047 & 38,50 & 0,0001 \\
$\mathrm{~N} / \mathrm{Fe}$ & 1,296 & 1,095 & 0,002 & 1,40 & 0,2640 \\
$\mathrm{P} / \mathrm{B}$ & 24,231 & 6,747 & 0,016 & 12,90 & 0,0049 \\
$\mathrm{~K} / \mathrm{S}$ & $-0,144$ & 0,024 & 0,044 & 36,58 & 0,0001 \\
$\mathrm{~K} / \mathrm{Fe}$ & 13,783 & 2,578 & 0,035 & 28,58 & 0,0003 \\
$\mathrm{Ca} / \mathrm{Cu}$ & 0,415 & 0,077 & 0,36 & 29,42 & 0,0003 \\
$\mathrm{Mg} / \mathrm{Fe}$ & $-33,092$ & 4,984 & 0,053 & 44,07 & 0,0001 \\
$\mathrm{Mg} / \mathrm{Zn}$ & $-3,487$ & 0,834 & 0,212 & 17,48 & 0,0019 \\
$\mathrm{~S} / \mathrm{Mn}$ & $-0,860$ & 0,240 & 0,016 & 12,84 & 0,0050 \\
$\mathrm{~S} / \mathrm{Zn}$ & $-4,224$ & 1,585 & 0,009 & 7,11 & 0,0237 \\
$\mathrm{~B} / \mathrm{Mn}$ & 0,012 & 0,004 & 0,010 & 7,99 & 0,0180 \\
$\mathrm{Cu} / \mathrm{Mn}$ & $-0,021$ & 0,012 & 0,003 & 2,84 & 0,1229 \\
$\mathrm{Fe} / \mathrm{Mn}$ & 0,005 & 0,002 & 0,006 & 4,84 & 0,0523 \\
\hline & & & & &
\end{tabular}


Tabela 37: Quadro da análise de variância, para a regressão múltipla entre os parâmetros da análise foliar e a relação sólidos solúveis:acidez total, o coeficiente de determinação $\left(\mathrm{R}^{2}\right)$ e o coeficiente de determinação ajustado $\left(\mathbf{R}_{\mathrm{a}}^{2}\right)$ para a equação.

\begin{tabular}{|c|c|c|c|c|}
\hline $\begin{array}{l}\text { Causas da } \\
\text { Variação }\end{array}$ & GL & $\mathbf{Q M}$ & $\mathbf{F}$ & Prob $>$ F \\
\hline Regressão & 18 & 6,121 & 36,20 & 0,0001 \\
\hline Resíduo & 11 & 0,169 & & \\
\hline Total & 29 & & & \\
\hline & \multicolumn{4}{|c|}{$\mathrm{R}_{\cdot \mathrm{a}}^{2}=0,955$} \\
\hline
\end{tabular}

Tabela 38: Quadro dos parâmetros da equação escolhida, para a regressão múltipla entre os parâmetros da análise foliar e a relação sólidos solúveis:acidez total.

\begin{tabular}{lccccc}
\hline \multicolumn{1}{c}{ Variável } & Estimativa & Erro padrão & SQ & F & Pr $>$ F \\
\hline Interseção & 53,712 & 3,447 & 41,062 & 242,83 & 0,0001 \\
$\mathrm{~B}$ & $-0,076$ & 0,021 & 2,311 & 13,67 & 0,0035 \\
$\mathrm{Cu}$ & 0,217 & 0,552 & 2,603 & 15,39 & 0,0024 \\
$\mathrm{Fe}$ & $-0,125$ & 0,011 & 21,110 & 124,84 & 0,0001 \\
$\mathrm{Mg}{ }^{2}$ & 1,535 & 0,131 & 23,398 & 138,37 & 0,0001 \\
$\mathrm{~N} / \mathrm{Mg}$ & 1,643 & 0,152 & 19,844 & 117,35 & 0,0001 \\
$\mathrm{~N} / \mathrm{Cu}$ & 22,487 & 4,621 & 4,004 & 23,68 & 0,0005 \\
$\mathrm{~N} / \mathrm{Zn}$ & $-20,870$ & 3,115 & 7,593 & 44,90 & 0,0001 \\
$\mathrm{P} / \mathrm{Mg}$ & $-46,673$ & 3,487 & 30,291 & 179,13 & 0,0001 \\
$\mathrm{P} / \mathrm{S}$ & $-4,756$ & 1,475 & 1,758 & 10,39 & 0,0081 \\
$\mathrm{~K} / \mathrm{Ca}$ & $-36,433$ & 3,259 & 21,130 & 124,96 & 0,0001 \\
$\mathrm{~K} / \mathrm{Mg}$ & 3,480 & 0,276 & 27,255 & 161,18 & 0,0001 \\
$\mathrm{Ca} / \mathrm{Zn}$ & $-12,192$ & 1,773 & 8,001 & 47,31 & 0,0001 \\
$\mathrm{Mg} / \mathrm{Cu}$ & $-212,619$ & 24,768 & 12,461 & 73,69 & 0,0001 \\
$\mathrm{Mg} / \mathrm{Fe}$ & $-148,750$ & 50,081 & 1,492 & 8,82 & 0,0127 \\
$\mathrm{~S} / \mathrm{Zn}$ & 134,090 & 19,023 & 8,402 & 49,69 & 0,0001 \\
$\mathrm{~B} / \mathrm{Cu}$ & 3,825 & 0,730 & 4,640 & 27,44 & 0,0003 \\
$\mathrm{Cu} / \mathrm{Fe}$ & $-115,350$ & 10,413 & 20,752 & 122,72 & 0,0001 \\
$\mathrm{Cu} / \mathrm{Zn}$ & 14,980 & 2,010 & 9,418 & 55,69 & 0,0001 \\
\hline & & & & &
\end{tabular}

